UNIVERSIDADE DE SÃO PAULO

ESCOLA DE ENFERMAGEM

VIVIAN ALINE MININEL

PROMOÇÃO DA QUALIDADE DE VIDA DOS

TRABALHADORES DE ENFERMAGEM:

RESPONSABILIDADE GERENCIAL DO ENFERMEIRO

SÃO PAULO

2006 
VIVIAN ALINE MININEL

\title{
PROMOÇÃO DA QUALIDADE DE VIDA DOS \\ TRABALHADORES DE ENFERMAGEM: \\ RESPONSABILIDADE GERENCIAL DO ENFERMEIRO
}

\begin{abstract}
Dissertação apresentada ao Programa de PósGraduação da Escola de Enfermagem da Universidade de São Paulo, área de concentração Administração de Serviços de Enfermagem, para obtenção do título de Mestre em Enfermagem.
\end{abstract}

Orientadora:

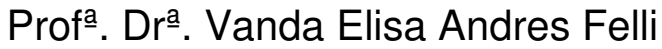

São Paulo

2006 
"Ainda que eu viva por toda a eternidade, Jamais serei capaz de agradecer o imenso amor Que Deus dedicou à mim!...” 


\title{
DEDICATÓRIA
}

\author{
A $\underline{\text { Deus... }}$ \\ Por ter me colocado no centro de Sua vontade, antes mesmo de minha \\ concepção.... \\ Por ter firmado meus passos em Seus caminhos aplainados... \\ Por me chamar de filha e me tomar em Seus braços, nos momentos de \\ desânimo.... \\ Por estar ao meu lado, mesmo nos momentos em que me sentia só... \\ Por permitir que Seus sonhos também fossem os meus sonhos e, assim, \\ torná-los reais... \\ Por ter me dado o que Ele tem de melhor: seu filho Jesus! \\ À Ele a Glória, a Honra e o Poder!
}




\section{AGRADECIMENTOS}

À maior amizade conquistada nestes últimos anos, minha querida orientadora e amiga Vanda Felli, por ter me mostrado que há valores que transpõem o conhecimento científico

Aos participantes desta pesquisa, por me permitirem realizá-la.

À FAPESP, pelo subsídio financeiro

Aos meus amados pais, Sirlei e Nelson, por suportarem a saudade e permitir que eu alçasse vôos mais altos

Ao meu querido irmão Ricardo, pelo apoio incondicional à "gorda"

A toda a minha família que amo, que me sustentou em oração e me apoiou, mesmo com lágrimas nos olhos devido à distância

Aos meus irmãos em Cristo, pela prontidão nas orações e por me amarem de uma forma que só o Pai pode explicar

Ao meu amigo e 'chefe' Sergio Candio, por possibilitar a realização deste sonho e permitir as ausências do trabalho

Aos amigos de todas as horas: Aninha e Fran (pelo carinho e atenção); Pri (por segurar todas as ondas); Wandeco (por acreditar em meu potencial) e especialmente ao Thiogro (pela disponibilidade e prontidão 24horas) - por todos terem sido olhos, ouvidos, mãos, alma e especialmente coração; por agüentarem meu choro, meu mau humor, meus dramas e pitis.

À todos vocês, meus eternos agradecimentos!!!

$$
\text { .b.e.i.j.o.s. }
$$


Mininel VA. Promoção da qualidade de vida dos trabalhadores de enfermagem: responsabilidade gerencial do enfermeiro [dissertação]. São Paulo (SP): Escola de Enfermagem da USP; 2006.

\section{RESUMO}

Este estudo objetiva analisar as ações voltadas para a promoção da qualidade de vida dos trabalhadores de enfermagem, desenvolvidas pelos enfermeiros que desempenham funções gerenciais. Para tanto, busca conhecer os processos destrutivos e favoráveis, determinantes dos processos saúde-doença, vivenciados pelos trabalhadores de enfermagem; apreender o significado da qualidade de vida no trabalho para estes trabalhadores; e, a partir daí, buscar propostas de intervenção para esta problemática. $O$ estudo, de abordagem qualitativa, fundamenta-se no referencial do materialismo histórico e dialético e na determinação social do processo saúde-doença. O cenário de estudo foi um hospital universitário, de grande porte, localizado na região centro-oeste do País. A população foi constituída por 22 trabalhadores, de diversas categorias de enfermagem, representantes das unidades e turnos de trabalho do Hospital. Para a coleta de dados foram utilizados formulários para captação dos dados de caracterização da instituição e dos trabalhadores, dos acidentes de trabalho e formulário com questões norteadoras das discussões no grupo focal. Ainda, a enquête coletiva foi utilizada para o registro dos dados discutidos neste grupo. A análise dos dados permitiu evidenciar que: os acidentes de trabalho com trabalhadores de enfermagem representaram, respectivamente, $51 \%$ e $25 \%$ do total de acidentes ocorridos nos anos de 2004 e 2005, causados principalmente pelos materiais pérfuro-cortantes; que a qualidade de vida e a qualidade de vida no trabalho são indissociáveis, sendo que a motivação para o trabalho e a satisfação advém da interação e reconhecimento dos pacientes, bem como pelas relações de confiança que são estabelecidas com a equipe de trabalho; que os processos favoráveis e destrutivos da saúde permeiam o momento de trabalho; que a exposição às diversas cargas, geradoras de processos de desgaste, evidenciaram um perfil destrutivo da saúde e, conseqüentemente, o comprometimento da qualidade de vida; que não existem programas ou ações institucionalizadas que promovam a qualidade de vida trabalho. A análise ainda possibilita a apreensão do desgaste psíquico sofrido pelos enfermeiros, na gerência, frente às mudanças no contexto de trabalho e seu impacto na qualidade de vida dos trabalhadores de enfermagem; que as mudanças e os desgastes evidenciados comprometem a atuação deste profissional como cuidador da equipe, promovendo um desgaste físico e mental no cumprimento das metas organizacionais. A análise evidencia, ainda, que inexistem iniciativas voltadas à promoção da qualidade de vida dos trabalhadores como uma responsabilidade gerencial e estas são relegadas a segundo plano, na emergência de situações demandadas no dia-a-dia de trabalho. Em síntese, constata-se que inexistem propostas de promoção da qualidade de vida dos trabalhadores de enfermagem ou estas são muito tímidas. Assim, emerge o imperativo da intervenção nas diferentes 
realidades, por enfermeiros preparados para gerenciar a promoção da qualidade de vida dos trabalhadores de enfermagem.

Descritores: Qualidade de vida no trabalho. Profissionais de enfermagem. Supervisão de enfermagem. Saúde ocupacional. 
Mininel VA. Promotion of nursing work's quality of life: managerial responsibility of nurse. [dissertação]. São Paulo (SP): Escola de Enfermagem da USP; 2006.

\begin{abstract}
This study aims to analyze the actions that are directed through the promotion of nursing workers quality of life, developed by the managerial nurses. For this, it searches to know the favorable and destructive processes, as determinants of the health-illness process lived by the nursing workers; to apprehend the means of work's quality of life for them; and, then, it searches proposals of interventions for this problematic situation. The study is based in the qualitative approach of historical and dialectic materialist and on referential of the social determination of the process health-illness. The setting of study was a big university hospital, which is situated in the centerwest region of Brazil. The population of study was composed by 22 nursing workers. They came from many units and shifts of work. Data collection about institution, workers profiles and occupational accidents was made by forms. Qualitative data was collected by collective interview in the focus group. Still, the collective inquiry was used to register the discussion of this group. The analysis of occupational accidents data evidenced that: in the years of 2004 and 2005, the nursing workers suffered a great number of these accidents, respectively, $51 \%$ and $25 \%$ of the total and that these accidents had as main cause due needlestick materials; analysis data also showed that the quality of life and work's quality of life are strongly linked and that the motivation and the satisfaction for the work come of the interaction and recognition with of the object of work, as well as for the relations that are established with the work team; that the favorable and destructive processes of health are determined in the workplace; that the exposition to diverse over workloads configures a destructive profile of the health and the consequence is the decrease of the quality of life; that it doesn't have institutional programs or institutional actions that promote the work's quality of life. Still, the analyze make possible the apprehension of the psychic strain suffered by the management nurses through the changes in the context from work and the impact from this in the nursing workers quality of life; that the changes and the strains compromise the performance of these nurses as manager of the team, promoting physical and mental strain in the fulfillment of organizational goals. The analysis evidences, still, that no have initiatives directed to the promotion of workers' quality of life as a management responsibility and these are relegated as the second plain, in the emergency of situations demanded in day-by-day of work. In synthesis, the study evidences that there haven't proposals for the promotions of nursing workers' quality of life or, if exist, these are very shy. Thus, the imperative of the intervention in the different ones realities emerges for prepared nurses to management the promotion of nursing workers' quality of life.
\end{abstract}


Key words: Work's quality of life. Nursing workers. Nursing management. Occupational health. 


\section{SUMÁRIO}

Interesse pela temática.................................................. 10

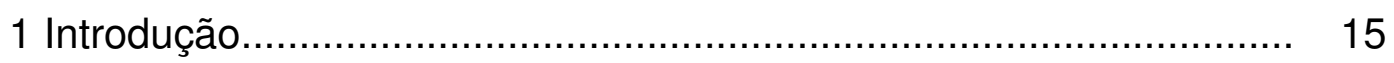

2 Objetivos....................................................................... 25

3 Construção do objeto de estudo............................................. 26

$3.1 \bigcirc$ trabalho em saúde..................................................... 26

3.2 Os processos de trabalho em enfermagem e a saúde dos 31 trabalhadores.

3.3 A qualidade de vida no trabalho................................... 39

4 Fundamentação teórico-metodológica...................................... 46

5 Caminho metodológico....................................................... 57

5.1 Tipo de estudo....................................................... 57

5.2 Cenário...................................................................... 57

5.3 População de estudo................................................. 63

5.4 Coleta de dados........................................................ 64

5.5 Tratamento dos dados................................................ 72

6 Análise e discussão dos dados............................................... 76

6.1 Perfil dos sujeitos de estudo.......................................... 76

6.2 Acidentes de trabalho............................................... 79

6.3 Processo de trabalho em enfermagem............................... 85

6.4 Qualidade de vida no trabalho........................................... 107

6.5 Processos favoráveis..................................................... 122

6.6 Processos destrutivos................................................... 126

6.7 Busca de proposições para intervenção na realidade.............. 156

7 Conclusão...................................................................... 162

Referências..................................................................... 169

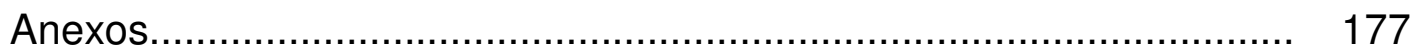




\section{INTERESSE PELA TEMÁTICA: motivação para o estudo}

O despertar para o tema Saúde do Trabalhador de Enfermagem em minha vida surgiu de forma relativamente tardia, contudo muito oportunamente. Enquanto graduanda do curso de Enfermagem, minha visão sobre o processo saúde-doença estava fortemente calcada nos pacientes aos quais eu prestava assistência. A relação desta temática com os trabalhadores de enfermagem ocorria de forma bastante superficial e limitava-se à associação com a prevenção de acidentes com pérfurocortantes e ao uso dos Equipamentos de Proteção Individual (EPIs).

No ano posterior da conclusão da graduação, ingressei no Curso de Especialização em Gerenciamento em Serviços de Saúde, oferecido pela Escola de Enfermagem da USP. Dentre as disciplinas que compunham a grade curricular, estava uma relacionada à Saúde do Trabalhador de Enfermagem e a Qualidade de Vida no Trabalho. O contato com esta temática incitou-me a entender como nós, profissionais que nos dedicamos a cuidar de vidas, estávamos recebendo cuidado, e até mesmo se o estávamos recebendo. Desta forma, comecei a buscar referências e estudos que pudessem subsidiar meus conhecimentos acerca do tema.

Encontrei diversos trabalhos direcionados a esta temática, especialmente àqueles relacionados à exposição dos trabalhadores de enfermagem às diversas cargas presentes no ambiente de trabalho. $O$ conhecimento do perfil de morbidade do trabalhador de enfermagem encontrava-se, de certa forma, delineado pelos diversos estudos realizados; 
contudo, poucos se concentravam em buscar alternativas que conseguissem solucionar ou, ao menos, minimizar a problemática vivenciada pelos trabalhadores.

Após o contato com estes estudos, emergiu a necessidade de entender como os enfermeiros, no gerenciamento de recursos humanos, promoviam ações relacionadas à saúde dos trabalhadores que estavam sob sua supervisão no campo de trabalho. Desta inquietude, desenvolvi a monografia de conclusão do Curso de Especialização com o seguinte tema: "Ações gerenciais relacionadas à qualidade de vida no trabalho de enfermagem: a percepção dos enfermeiros" (Mininel, 2004).

Este estudo foi realizado com enfermeiros diretores de área de um hospital da cidade de São Paulo, e teve como objetivo compreender as ações desenvolvidas por estes profissionais junto à equipe de enfermagem, voltadas à qualidade de vida no trabalho. Como resultado, as falas mostraram que poucas ações tem sido desenvolvidas por estes enfermeiros e que inexistem políticas institucionais que orientem, de forma sistematizada, tais práticas. Neste sentido, estes profissionais acabam por realizar ações de ordem pessoal e pontual, no intuito de solucionar eventuais problemas demandados.

Os resultados deste estudo, bem como o acompanhamento constante de novas pesquisas produzidas, motivaram-me a buscar uma melhor compreensão sobre o universo de significados que circunda o dia-a-dia de trabalho de enfermagem e, especialmente, conseguir apreender qual a 
percepção atribuída pelos trabalhadores à sua qualidade de vida no trabalho.

$\mathrm{Na}$ busca constante de elucidações que, de alguma forma, pudessem embasar um plano de intervenções que viesse a contribuir com a promoção da qualidade de vida no trabalho dos profissionais de enfermagem, ingressei no Curso de Mestrado do Programa de Pós-Graduação, na Escola de Enfermagem da USP, na área de concentração Administração em Enfermagem, para desenvolver dissertação na temática Saúde do Trabalhador de Enfermagem.

Esta conquista possibilitou minha participação no Grupo de Pesquisa "Estudos sobre a saúde do trabalhador de enfermagem" cadastrado junto ao Conselho Nacional de Desenvolvimento Científico e Tecnológico (CNPq). Conseqüentemente, ocorreu minha inserção na equipe de pesquisadores que o compõe, no Projeto: "Monitoramento da Saúde do Trabalhador de Enfermagem: promovendo a qualidade de vida no trabalho", apoiado pela FAPESP, do qual esta dissertação faz parte.

Com o intuito de conhecer o estudo desta temática mundialmente, participei do International Symposium Satellite to $I C O H 2006$ - Shiftwork and ageing in health care and community services e do 28th International Congress on Occupational Health - ICOH 2006. Nestes dois eventos de relevância internacional em saúde ocupacional, apresentei estudos desenvolvidos por mim e pela profạ. Vanda. Tive, também, a oportunidade de conhecer outros pesquisadores e estudos desenvolvidos em diferentes países. 
Esta experiência na participação de eventos internacionais proporcionou-me realizar algumas análises acerca do tema saúde ocupacional, como seguem abaixo:

- a preocupação com a saúde dos trabalhadores cada vez mais tem se tornado um assunto de interesse mundial e muitas pesquisas vêm se desenvolvendo nas mais diversas áreas do setor produtivo, visando conhecer o perfil de adoecimento dos trabalhadores e subsidiar possíveis formas de intervenção da realidade;

- a maioria dos estudos são desenvolvidos na abordagem quantitativa; a abordagem qualitativa tem crescido muito timidamente e, apesar de significativa, não é numericamente expressiva fora do país;

- os trabalhadores de enfermagem têm sido, freqüentemente, sujeitos dos estudos no contexto mundial, evidenciando a problemática vivenciada;

- a Universidade de São Paulo destacou-se com a qualidade e ineditismo das pesquisas apresentadas sobre esta temática;

- o tema qualidade de vida do trabalhador de enfermagem não apareceu de forma expressiva nas pesquisas realizadas, o que reforça a relevância deste estudo.

O reconhecimento do contexto internacional e da carência de estudos que possam contribuir para o entendimento de como o processo saúdedoença dos trabalhadores de enfermagem, bem como dos processos que favoreçam a promoção da qualidade de vida no trabalho como ação gerencial, motivou-me sobremaneira a investigar a realidade destes 
trabalhadores e a construir, em parceria com os mesmos, possíveis ações de intervenção que corroborem ao desenvolvimento de políticas institucionais ou públicas de promoção da saúde destes trabalhadores. 


\section{NTRODUÇÃO}

As atuais políticas sociais e de saúde resultam de um processo histórico evolutivo, desenvolvido paralela e dependentemente ao contexto político-econômico de cada época. A constituição desta evolução só foi possível por meio dos atores sociais que compunham a sociedade em cada período específico e, ainda hoje, constituem-se em agentes de mudança da realidade.

O ser humano, entendido neste contexto como um ser dotado da capacidade para exercer mudanças na realidade, viabiliza este status mediante seu modo de inserção social na comunidade. De acordo com a consideração de Marx (1982), a relação do homem com a natureza ocorre pelo trabalho. Assim, considerando a natureza como o contexto social no qual o homem está inserido, apreende-se que esta relação ocorre por intermédio do trabalho que este indivíduo exerce. É também pelo trabalho que o indivíduo adquire uma identidade social e que as relações de reciprocidade são estabelecidas.

Inevitavelmente, a política sócio-econômica determina as esferas de inserção do indivíduo na sociedade, por meio do acesso aos bens de consumo que the é conferido. O contexto atual, marcado pela hegemonia capitalista, de traço neoliberal, somado à inovação tecnológica constante e compulsória, delineou um cenário bastante conflitivo para as relações de trabalho, já que a teia de emaranhados que compõe o setor de produção tornou-se mais vulnerável às tendência e decisões políticas. 
Esta realidade tem afetado, de forma bastante significatia, o papel desempenhado pelo trabalhador em seu ambiente de trabalho, percebendose como mero instrumento. Esta percepção é reforçada pelo enfoque mercadológico voltado a valorização do capital, que tem gerado uma desigualdade em relação às expectativas dos trabalhadores e do trabalho.

No sentido fisiológico, todo trabalho é dispêndio de força humana e, nesta condição de trabalho humano, origina valores de mercadorias. Este trabalho, na qualidade de trabalho útil e concreto determinado a algum fim, cria valores-de-uso (Marx, 1982).

Felli e Peduzzi (2005) permitem evidenciar o setor terciário de prestação de serviços em saúde como caracterizado por produzir bens de consumo não palpáveis e consumíveis no ato de sua produção. Deste modo, o trabalhador estabelece a relação de troca com o empregador, que compra sua força de trabalho como uma mercadoria diferenciada - já que o potencial de barganha está na sua capacidade de trabalho, que adquire valor de mercadoria.

Esta visão economicista das capacidades para o trabalho implica na necessidade do trabalhador de preservar-se em condições adequadas para o desempenho destas capacidades, que ocorre na interação deste agente com os constituintes do trabalho (relação com o objeto, meios e instrumentos e formas de organização e divisão do trabalho). Desta forma, o trabalhador busca a superação de seus limites e incapacidades para o alcance das recompensas financeiras decorrentes da execução de seu trabalho (valores-de-uso) e reconhecimento econômico junto ao empregador 
(valor de mercadoria). Ou seja, a utilidade de determinado trabalho é o que Ihe confere valor de uso, concretizado pelo consumo.

Laurell e Noriega (1989) afirmam que a valorização capitalista ocorre no momento concreto da produção de bens de serviços, ou seja, no processo de trabalho. O trabalho, então, passa a ser desenvolvido por processos caracterizados pelas relações estabelecidas entre os trabalhadores e a fonte empregadora.

Felli (2002), analisando as relações de trabalho nesta mesma perspectiva, refere que o capitalismo cria uma sociedade onde imperam interesses próprios e onde a gerência torna-se um instrumento perfeito e sutil nas relações de trabalho estabelecidas entre empregado e empregador.

A interface do gerente frente aos interesses dos trabalhadores e da instituição submete-o ao papel de articulador do antagonismo apresentado pelas distintas expectativas e necessidades no processo de trabalho. Ao mesmo tempo em que este ator social representa e personifica as imposições demandadas pela hierarquia superior, ele também (co)responde aos interesses e necessidades buscados pelos trabalhadores, intermediando estas duas forças distintas (a força de trabalho e o poder de compra).

O trabalho de enfermagem, inserido no contexto de trabalho multidisciplinar de saúde, também compõe o cenário conflitivo de interesses distintos, especificamente por ser uma profissão que trabalha, necessariamente, em equipe. Isto porque, no Brasil, a enfermagem é composta por três categorias profissionais interdependentes, reconhecidas junto ao Conselho Federal de Enfermagem (COFEn), que são: enfermeiros, 
técnicos e auxiliares de enfermagem. Assim, além das relações estabelecidas com empregador e demais profissionais, a enfermagem lida com uma equipe própria de trabalho, sob responsabilidade do enfermeiro.

Assim, o processo gerencial realizado pelo enfermeiro nas instituições de saúde, está imbuído de muitas possibilidades de intervenções e transformações que objetivam a melhoria das condições de trabalho, com vistas à qualidade de vida dos pacientes e dos trabalhadores de enfermagem, constituindo-se em instrumento necessário à implementação de políticas institucionais que abarquem as questões da saúde no trabalho (Felli, 2002).

Desta forma, este profissional deve desempenhar as funções que lhe são atribuídas pela instituição, fazendo cumprir as determinações impostas por esta, e também assumir a responsabilidade de gerente do cuidado junto aos demais trabalhadores que compõem a equipe de enfermagem, no que se refere aos cuidados com a saúde no ambiente de trabalho.

Ao longo dos anos, vários pesquisadores têm se empenhado em estudar a saúde dos trabalhadores e buscar os determinantes dos desgastes e morbi-mortalidade desta população. Semelhantemente na Enfermagem, estes estudos têm objetivado subsidiar possíveis intervenções junto às instituições estudadas e, prioritariamente, junto aos enfermeiros gerenciais, como forma de proteger os trabalhadores de enfermagem dos riscos e cargas a que estão expostos.

Silva (1996), em um importante estudo sobre as cargas e acidentes de trabalho com trabalhadores de enfermagem em uma instituição 
hospitalar, demonstrou o perfil de saúde-doença e a exposição destes trabalhadores aos diversos fatores que comprometem à saúde no ambiente de trabalho. Nesta mesma linha, voltado à exposição às variadas cargas e acidentes de trabalho, aparecem estudos recentes, como de Sarquis (1999); Canini, Gir, Hayashida, Machado (2002); Gurgueira, Alexandre, Corrêa Filho (2003); Gutierrez (2003); Araújo, Aquino, Menezes et al (2003); Nishide, Benatti, Alexandre (2004); Marziale, Nishimura, Ferreira (2004); Canini, Gir, Machado (2005); Almeida, Pagliuca, Leite (2005); Costa, Felli (2005); Murofuse, Marziale (2005); Balsamo, Felli (2006); Xalengati, Robazi, Marziale, Haas (2006); Batista, Bianchi (2006); Cruz (2006).

Estes estudos apresentam, com bastante propriedade, as formas de exposição aos fatores de desgaste no ambiente de trabalho e os acidentes ocasionados por esta exposição e, conforme apontado por Felli (2002), também diagnosticam como as formas de organização do trabalho de enfermagem em suas diversas dimensões são geradoras de diferentes processos saúde-doença, o que demonstra a emergência de mudanças nesta realidade de trabalho.

O momento de trabalho concretiza a exposição às cargas, tanto no espaço físico, quanto na intersubjetividade que permeia as relações. Desta maneira, faz-se necessário conhecer este locus e entender como ocorrem os processos de trabalho, buscando tais informações pelas percepções dos próprios atores sociais que compõe esta realidade. Ou seja, o entendimento dos problemas de saúde vivenciados pelos trabalhadores de enfermagem deve ser buscado na internalidade do processo de trabalho (Felli, 2002). 
Este conhecimento permite a identificação de fatores que comprometem a manutenção do estado de saúde no trabalho e, assim, colaboram para a diminuição da qualidade de vida. Para esta análise, também é necessário entender o que cada trabalhador entende por qualidade de vida no trabalho e quais são os fatores que potencializam a qualidade de vida ou a corrompem, na visão coletiva.

Felli e Tronchin (2005) expõem que a manutenção da qualidade de vida no trabalho é um desafio para os enfermeiros que assumem a gerência e, também, para os trabalhadores de enfermagem. No gerenciamento, os enfermeiros devem assumir a responsabilidade quanto à promoção de ações que favoreçam a saúde dos demais trabalhadores de enfermagem e que minimizem os impactos advindos das cargas e processos de desgastes presentes nas atividades cotidianas.

Esta responsabilidade, além de percebida pelo enfermeiro que lidera a equipe, deve ser diagnosticada como objeto passível de intervenção, uma vez que há pesquisas que instrumentalizam e norteiam possíveis ações direcionadas. Observa-se que, devido ao reconhecimento de que a instituição ocupa um importante papel (senão o mais importante) em relação à saúde dos trabalhadores, que os enfermeiros têm-se limitado ao levantamento de problemas e negligenciado à busca de soluções para os mesmos. Com isso, omitem-se na culpabilidade atribuída à instituição.

Isto não significa que os enfermeiros são a causa de seus males, tampouco responsáveis pelo desgaste e adoecimento da equipe, mesmo porque estes são, muitas vezes, inerentes ao exercício do trabalho. 
Porém, a assunção desta realidade mascara o papel gerencial frente às condições de saúde dos trabalhadores. Também a instituição omite-se no seu papel pela não fiscalização quanto ao cumprimento dos dispositivos legais referentes à saúde dos trabalhadores. Frente a esta postura, os trabalhadores tornam-se desprotegidos, sofrendo impacto de tal situação.

Entretanto, por ser sua capacidade de trabalho o valor de troca junto ao empregador, o trabalhador submete-se às estas diversas situações sob pena de ser excluído do convívio social e cerceado de seu poder de compra.

Nesta perspectiva, também os enfermeiros sofrem o impacto enquanto trabalhadores e, ainda pela limitação do exercício da autonomia nas decisões, enquanto no papel gerencial.

No entanto, questiona-se: será que realmente é este conformismo que tem motivado os trabalhadores a permanecerem em seus trabalhos? Será que a passividade tem dominado as relações de poder e isso tem impedido o desenvolvimento de melhorias pela saúde dos trabalhadores? Será que as capacidades humanas estão com seu valor de mercadoria tão desvalorizado a ponto de ser trocado por qualquer oferta?

Se se parte do pressuposto que a saúde do trabalhador é de responsabilidade da instituição contratante, exime-se os demais trabalhadores quanto à sua participação na construção de processos de trabalho que corroborem para a manutenção e promoção da saúde no ambiente de trabalho. Entretanto, este estudo alicerça-se nos papéis dos enfermeiros que assumem funções gerenciais e dos trabalhadores que estão 
submetidos como eixo principal das ações voltadas à saúde dos trabalhadores de enfermagem.

Assim, a proposição deste trabalho é apreender as necessidade e expectativas dos enfermeiros que desempenham funções gerenciais e demais trabalhadoras em relação à saúde e qualidade de vida no trabalho.

Para tanto, buscou-se na literatura, estudos que pudessem ajudar na melhor compreensão da temática.

Felli (2002), em uma abordagem reflexiva, apresenta a gerência como meio instrumento para a transformação do processo de trabalho e saúde dos trabalhadores de enfermagem, pela utilização de instrumentos como supervisão, educação continuada etc, em uma nova abordagem.

O processo gerencial realizado pelo enfermeiro nas instituições de saúde, como considera Rocha (2003), está imbuído de muitas possibilidades e intervenções e transformações que objetivam a melhoria das condições de trabalho, com vistas à qualidade de vida dos pacientes e dos trabalhadores de enfermagem. É, portanto, instrumento necessário à implementação de políticas institucionais que abarquem as questões de saúde no trabalho.

Murofuse, Abranches, Napoleão (2005) referem que, ainda que o exercício da profissão de enfermagem requeira boa saúde física e mental, raramente os enfermeiros recebem a proteção social adequada para o seu desempenho, expondo-se, assim, aos acidentes e doenças ocupacionais.

Devido a isso, o estudo das relações entre trabalho-saúde tem merecido atenção de muitos pesquisadores, destacando-se os prejuízos à saúde física e mental dos trabalhadores decorrentes das condições de 
trabalho (como prolongadas jornadas de trabalho; ritmo acelerado de produção por excesso de tarefas; automação por realização de ações repetitivas com parcelamento de tarefas e remuneração baixa, em relação à responsabilidade e complexidade das tarefas executadas). Em tais situações, muitas vezes, o trabalho deixa de significar satisfação, ganhos materiais e serviços sociais úteis, para tornar-se sofrimento, exploração, doença e morte (Barboza, Soler; 2003).

Neste cenário apresentado urge a necessidade de transformação da realidade, que vem sendo enfatizada há alguns anos, em estudos como de Silva, Kurcgant, Queiroz (1998) e ratificada nos anos seguintes, como nas afirmações de Felli e Tronchin (2005). Eles evidenciam que há, cada vez mais, a necessidade de articulação de estratégias que apontem para investimento nas relações interpessoais; implementação de ações e programas que venham ao encontro das expectativas dos trabalhadores de prestar o cuidado ao mesmo tempo em que são cuidados pela organização.

Diante desta necessidade, os achados de Felli (2002), corroborados por Cruz (2006), apontam que o conhecimento acerca da produção científica sobre os problemas de saúde dos trabalhadores de enfermagem ainda não foi suficientemente incorporado pelos dirigentes das instituições e nem pelos trabalhadores, indicando um longo caminho até um sistema que incorpore intervenção e avaliação.

Diante destas constatações que apontam para caminhos divergentes, o presente estudo desenvolve-se na perspectiva de apreender as necessidades referidas pelos trabalhadores de enfermagem e pelos 
enfermeiros que assumem funções gerenciais frente à situação de perda de anos de vida (ou vida de anos) dos trabalhadores de enfermagem. 


\section{OBJETIVOS}

- Conhecer os fatores destrutivos e favoráveis do processo saúde-doença no ambiente de trabalho dos trabalhadores de enfermagem;

- Conhecer o significado para os trabalhadores de enfermagem em relação à qualidade de vida no trabalho;

- Conhecer quais ações sistematizadas são desenvolvidas pelos enfermeiros e favorecem a qualidade de vida no trabalho de enfermagem;

- Conhecer as expectativas dos trabalhadores de enfermagem quanto às ações que favoreça a qualidade de vida no trabalho;

- Discutir, com os trabalhadores de enfermagem, propostas de intervenção voltadas à promoção da qualidade de vida no trabalho daquela realidade, pelos enfermeiros gerenciais. 


\section{CONSTRUÇÃO DO OBJETO DE ESTUDO}

\subsection{O trabalho em saúde}

Entender a enfermagem como prática social implica em contextualizála nas políticas sociais, econômicas e de saúde no País e no mundo. As práticas sociais organizam-se mediante as necessidades sociais e são concretizadas pelo trabalho.

O trabalho ocupa cerca de um terço de tempo da vida dos indivíduos, atribuindo diferentes significados às diversas fases da vida, como a fase produtiva e a aposentadoria. Assim, é o trabalho que, desde a infância até à entrada no mercado, concretiza os esforços direcionados à educação de qualidade e possibilite a inserção em um campo de trabalho. Na fase laboral, os esforços voltam-se para o crescimento profissional, para conquista de reconhecimento e melhor remuneração. Enquanto na aposentadoria, o indivíduo busca-se usufruir da saúde e conforto adquirido com os anos de trabalho.

Entretanto, a vida produtiva, na maioria das vezes, está associada a um período de trabalho intenso, geralmente em condições inadequadas e desgastantes que deterioram a saúde em detrimento do acúmulo de reservas financeiras que, na verdade, serão gastas posteriormente para a recuperação da saúde perdida nos anos de trabalho. Ou seja, perde-se a 
saúde hoje para ganhar dinheiro que será gasto amanhã para recuperar-se a saúde.

Para Faria, Silva, Patrício (1999), o trabalho apresenta-se como um componente essencial na vida dos seres humanos quanto à satisfação e realização cotidiana dos desejos e necessidades de ter, ser, estar e fazer individual e coletivo. Esta evidência adquiriu proporções gigantescas com o incremento do capitalismo, que instituiu a sensação de insatisfação constante e um consumismo desenfreado.

Esta necessidade de ter e ser resulta da globalização excludente, que destrói as possibilidades de inserção na sociedade, uma vez que limita as oportunidades de trabalho. Assim, considerando-se o emprego como base da inclusão social primária e a mundialização do capital tendem a vulnerabilizar os trabalhadores de forma acentuada, implicando na aceitação a crescente deterioração das relações de trabalho (Baraldi, 2005) e, também, da própria condição de vida.

Para Marx (1982), a força de trabalho é uma mercadoria valorada em montantes financeiros, estabelecidos na base da troca. Ou seja, o trabalhador vende sua força de trabalho a um preço negociado com o empregador que possui o poder de compra. Deste modo, as relações são estabelecidas de forma que, mesmo interdependendo-se, seja extraída a maior vantagem para cada um dos lados. Assim, a tendência de geração de mais-valia imposta pela economia capitalista, ocorre na base da exploração da força de trabalho e alienação do trabalhador - que explica a característica 
destrutiva e não potencializadora das capacidades humanas dos trabalhadores (Laurell, Noriega, 1989).

Cattani (1997) utilizando-se das considerações de Marx (1982), coloca que o trabalho resulta do dispêndio de energia física e mental, direta ou indiretamente voltada à produção de bens e serviços contribuindo, assim, para a reprodução da vida individual e social. A reprodução social implica na inserção do indivíduo na sociedade e do acesso aos padrões de consumos, mediante seu poder de compra.

Os interesses entre trabalhadores e empregadores são bastante distintos. Os trabalhadores, que esperam a justa remuneração pela aplicação de sua força de trabalho se opõem aos empregadores, que subvalorizam os potenciais humanos mediante a exploração do trabalho ou não remuneração correspondente ao tempo real investido. Ou seja, tudo se torna passível de negociação, inclusive o ser humano e suas capacidades.

Esta situação ocorre e é mantida pela própria máquina econômica, impulsionada pelas necessidades da sociedade. Assim, o indivíduo vende sua força de trabalho para conseguir acesso aos bens de consumo, mediante o poder de compra conferido com o pagamento de seu trabalho. Para que suas necessidades sejam satisfeitas, submete-se aos processos de geração de valor. O empregador, que detém o poder de compra dos trabalhadores, busca extrair o máximo deste indivíduo pagando o mínimo possível, de forma que o trabalho seja executado pelo menor número de pessoas e seja garantida a maior lucratividade possível. 
O processo de valorização se concretiza no momento da produção de bens e serviços. A extração de mais-valia pode ocorrer pelo aumento da jornada de trabalho ou pela redução do salário (mais-valia absoluta) e, ainda, pela intensificação do ritmo de trabalho ou pela introdução de novas tecnologias (mais-valia relativa) (Laurell, Noriega, 1989).

A produção de mais-valia implica nas relações interpessoais de trabalho. A organização institucional, com seu caráter exploratório e alienante, superutiliza a força de trabalho para extrair maior produtividade. Esta forma de valorização do capital é geradora, em efeito dominó, de morbidades e incapacidades coletivas.

Silva (1996), fundamentada na concepção marxista, considera a intencionalidade imbuída nas atividades de trabalho e direcionada à transformação do objeto em um produto inicialmente pré-concebido. Assim, o trabalhador dispõe dos meios e instrumentos para a transformação do objeto,mediante determinadas formas de organização do trabalho.

Marx (1982) considera o trabalho como sendo o processo participativo entre o homem e a natureza, no qual o homem transforma a natureza mediante o uso de sua força e de seu controle sobre os instrumentos de trabalho. Ao mesmo tempo em que o trabalhador transforma a natureza, ele também se transforma. Ou seja, o trabalhador imprime sua marca no trabalho que executa, mas também sofre a impressão deste em sua vida.

As marcas referidas no excerto acima não são, necessariamente, positivas ou negativas. Nesta perspectiva, a busca direciona-se para que a interação no trabalho gere, na maioria das vezes, processos que favoreçam 
bilateralmente os envolvidos na relação e imprimam marcas que irão colaborar com a sensação de melhoria da qualidade de vida.

Laurell e Noriega (1989) analisam que no processo de trabalho existem elementos que interatuam dinamicamente entre si e com o corpo do trabalhador, gerando processos de adaptação que se traduzem em desgaste - cargas de trabalho. Esses processos, entendidos como a perda da capacidade potencial ou efetiva corporal e psíquica constituem no processo de desgaste.

A adaptação é conceituada pelos autores como a capacidade do corpo em responder com plasticidade diante das condições específicas de desenvolvimento nos processos corporais e manifesta-se a partir da atividade humana no trabalho e sua historicidade (processo social), determinantes do processo saúde-doença.

Os processos de desgaste podem ser reconhecidos como uma marca gerada pelo trabalho no momento de sua execução. O processo saúdedoença pode ser compreendido como decorrente da reprodução social de um grupo com características específicas, que vai acarretar no aparecimento de manifestações patológicas no corpo do indivíduo sadio.

Laurell e Noriega (1989) consideram que a complexidade do desgaste faz com que haja dificuldade para mostrá-lo diretamente, sobretudo porque em sua maior parte é inespecífico e não se expressa com clareza em elementos facilmente observáveis ou mensuráveis.

Talvez este seja um dos motivos que justifiquem a afirmação em que Breilh (1990) coloca que a maior parte das pessoas e, muitos profissionais 
de saúde, por falta de consciência, pensam que a doença se reduz a problemas que ocorrem no indivíduo. Refere ainda que, na verdade, os problemas determinantes das enfermidades, não só são gerados nos organismos individuais e não só se concentram no corpo humano, mas são processos que se geram na dimensão social da vida e têm suas raízes nos modos de organização da sociedade. Fundamentalmente, também têm raízes nos correspondentes padrões de trabalho e de costume de um grupo. O autor conclui a concepção de determinação do processo saúde-doença do plano individual para o plano coletivo-social, numa corrente contrahegemônica ao modelo biomédico.

Assim, o trabalho pressupõe uma relação dialética com o objeto e meios de trabalho, numa relação de transformação que, traduzida em desgaste no corpo do trabalhador, desencadeia o processo saúde-doença, comprometendo a qualidade de vida.

\subsection{Os processos de trabalho de enfermagem e a saúde dos trabalhadores}

Igualmente aos demais setores terciários de produção de serviços, a Enfermagem sofre os impactos das tendências e políticas vigentes no cenário sócio-econômico do País. Esta exposição às inconstâncias do cenário nacional e mundial, no qual o neoliberalismo faz de uma situação isolada uma cascata de outros acontecimentos associados que afetam 
diferentes realidades em diversos locais do mundo, fragiliza as relações que são estabelecidas entre o agente de trabalho e o mercado que o consome.

Somado a este cenário de incertezas, Felli (2002) aponta que o trabalho de enfermagem apresenta um diferencial em relação aos outros setores do setor terciário e da prestação de serviços, por lidar cotidianamente com grandes paradoxos, com a vida e a morte, a dor e o prazer. Esta convivência intensa com situações conflitantes desencadeia no trabalhador sentimentos distintos, que alternam entre momentos de euforia e profundas tristezas.

As relações estabelecidas no trabalho de enfermagem, considerando ora o seu ambiente propriamente dito de trabalho, ora o contexto no qual ele se insere, são geradoras de sentimentos que desencadeiam processos benéficos ou maléficos à saúde. Assim, a relação que o trabalhador estabelece com o objeto de trabalho frente às necessidades por ele demandadas gera uma troca mútua e subjetiva de sensações que culminará em uma transformação para ambos envolvidos.

A interação com este objeto, o trabalhador deve considerar a natureza física, química ou biológica que, por sua vez, recai nas propriedades biológica ou psíquica individuais, como determinante do processo saúdedoença do trabalhador de enfermagem (Silva, 1996).

Para a transformação do objeto, utilizam-se os meios e instrumentos de trabalho. É no processo de trabalho cuidar / assistir que se tem maior visibilidade das cargas decorrentes da interação do trabalhador com os meios e instrumentos de trabalho. Neste processo, os instrumentos tais 
como materiais e equipamentos são facilmente associados aos acidentes e doenças (Silva 1996). Constituem-se, ainda, meios de trabalho a força de trabalho dos trabalhadores, o saber e a área física onde este trabalho é exercido.

No trabalho, as atividades são realizadas mediante formas de organização, nas quais se sobressai a divisão do trabalho em equipe, atividades, categorias, turnos; a supervisão realizada pelo enfermeiro; baixa remuneração e relações verticalizadas. Destas formas de organização, apreende-se dois processos diferenciados de trabalho - 0 processo assistencial, desenvolvido pelos técnicos e auxiliares de enfermagem e o processo gerencial, desenvolvido, predominantemente, pelo enfermeiro (Silva 1996).

Partindo-se desta análise, o foco das ações do enfermeiro deve atentar para o trabalho enquanto processo desenvolvido em equipe que sofre os desgastes impostos pela cotidianidade do trabalho. Silva (1996) aponta que, no caso do trabalho da enfermagem, a geração de mais-valia ocorre pela intensificação do ritmo de trabalho imposto pela aceleração desgastante do ritmo de trabalho na realização das tarefas.

Em qualquer tipo de trabalho, o sujeito da ação irá sofrer algum tipo de transformação decorrente desta sua interação com objeto, meios e instrumentos de trabalho. $\mathrm{Na}$ enfermagem, os estudos vêm se desenvolvendo objetivando conhecer quais são estas alterações e como elas afetam o trabalhador em seu ambiente de trabalho. 
Silva (1996), demonstra que o trabalhador de enfermagem está submetido cotidianamente às cargas mecânicas, químicas, físicas, biológicas, fisiológicas e psíquicas. A ação destas cargas sobre o corpo do trabalhador traduz-se em desgastes físicos e mentais, que desencadeiam a incapacidade para o trabalho.

Silva e Massarollo (1998) mostram o desgaste do trabalhador como sendo resultante dos fatores destrutivos no trabalho.

Breilh (1990) acrescenta, considerando que os aspectos de reprodução social no trabalho apresentam contradições referentes à saúde; ou seja, o processo de trabalho não é puramente saudável, nem excessivamente destrutivo: os aspectos benéficos e suas facetas destrutivas coexistem.

Esta consideração remete o trabalho a um contexto contraditório entre os aspectos que ora promovem à saúde e ora a destroem. Assim, observase no contexto do trabalho, que os fatores destrutivos se sobreponham aos fatores favoráveis, desencadeando a deteriorização da saúde e o declínio da qualidade de vida. Isso pode ser evidenciado nos trabalhos de Laurell e Noriega (1989), que aborda este desequilíbrio com operários da produção minero-siderúrgica; e de Silva e Massarollo (1998), que fazem a leitura da realidade do trabalho de enfermagem.

Em ambos os estudos observam-se a prevalência dos fatores destrutivos e conseqüente desgaste dos trabalhadores. O perfil destrutivo do trabalho é conformado pela alienação, subordinação e hierarquização dos trabalhadores de enfermagem; pela exposição às sobrecargas e subcargas que geram processos de desgaste; pela falta de autonomia e criatividade; 
pela elevada rotatividade e pela desarticulação de defesas coletivas (Silva, Massarollo, 1998).

Em relação às estas cargas de trabalho, Silva (1996) descreve as cargas biológicas como sendo aquelas que ocorrem pelo contato com pacientes portadores de doenças infecciosas, infecto-contagiosas ou parasitárias e/ou com suas secreções, contatos com materiais contaminados e com pequenos animais; as cargas físicas como provenientes de ruídos e sons, umidade, iluminação, alterações bruscas de temperaturas, eletricidade, radiações; as cargas químicas decorrentes da exposição do trabalhador às substâncias químicas em diferentes estados físicos; as cargas mecânicas oriundas da manipulação de materiais pérfuro-cortantes, quedas, agressões, preensão de dedos e mãos; as cargas fisiológicas originadas pela manipulação excessiva de peso, trabalho noturno ou em rodízio de turnos, realização das atividades predominantemente em pé e outras posições inadequadas. Descrevem ainda as cargas psíquicas como resultantes da atenção constante do trabalhador; da supervisão estrita; do ritmo acelerado; do trabalho parcelado, monótono e repetitivo; da dificuldade de comunicação; do trabalho predominantemente feminino; da desarticulação de defesas coletivas; da agressão psíquica, da fadiga, tensão, estresse; e da insatisfação no trabalho.

Esta contradição entre os processos favoráveis e destrutivos da saúde presentes na interação com os processos de trabalho expõem o trabalhador às diferentes formas de consumo de sua força de trabalho, que implicam em distintas maneiras de desgastar-se (Silva, 1996). 
Desta forma, o trabalho passa a ser um ambiente predominantemente maléfico à saúde dos trabalhadores, reflexo da estrutura organizacional na qual os processos se desenvolvem. Este provoca o consumo não apenas da força de trabalho, mas também da vida, já que o processo de desgaste compromete a qualidade de vida.

\subsubsection{A gerência em enfermagem}

Uma tradição que a enfermagem vem nutrindo desde seu princípio é a dicotomia existente entre a concepção e a execução do trabalho. É como se a profissão ainda estivesse dividida em lady nurses e nurses, sendo as primeiras responsáveis pelo planejamento do trabalho e as segundas pela execução. É fato que esta divisão não mais existe; entretanto, ela está representada em uma outra divisão dentro da equipe, de caráter técnico e social, evidenciada nas atividades e atribuições entre enfermeiros, técnicos e auxiliares de enfermagem.

Esta divisão faz com que o trabalho desempenhado pelo enfermeiro seja constituído, prioritariamente, pelo gerenciamento de ações que são executadas pelos demais membros da equipe. Tudo o que é realizado pela equipe de enfermagem é planejado, coordenado, executado, avaliado e controlado pelo enfermeiro, ocupando ele cargo de chefia ou não. Este trabalho é marcado, ainda hoje, pela sedimentada hierarquia e distanciamento ente as categorias. 
Esta hegemonia histórica pode ser explicada pelos anos de subordinação ao modelo de administração taylorista, calcado nas relações marcadas pela hierarquização, racionalidade e subordinação. Esta permeabilidade dos serviços de saúde a este modo de organização de trabalho molda, ainda hoje, os padrões de comportamento, dificultando a construção de novos valores.

Felli (2002) refere-se ao gerenciamento como sendo incorporado ao trabalho de enfermagem, e como sendo realizado, prioritariamente, pelo enfermeiro. Nesta visão, o enfermeiro torna-se o gerenciador da equipe e assume a responsabilidade junto a ela.

Mishima et all (1997) consideram a gerência como um instrumento importante para a efetivação de políticas; ela é, ao mesmo tempo, condicionante do e condicionada pelo modo como se organiza a produção dos serviços. Nesta perspectiva, pode-se refletir que, se a gerência constituise em instrumento para efetivação de políticas, é ela quem tem ou agrega poder de transformação da realidade.

Nesta concepção de gerenciamento realizada pelo enfermeiro, o objeto de trabalho passa a ser constituído tanto pelos trabalhadores que compõem a equipe de enfermagem, quanto à própria organização necessária para a efetivação da assistência (Felli, Peduzi, 2005).

Tomando-se o processo de trabalho gerencial realizado pelo enfermeiro, torna-se imprescindível o compartilhamento de informações numa relação de mão dupla, na qual haja o encorajamento e fortalecimento de troca de experiências e vivências (Campos, 1997). 
Contudo, o compartilhamento de informações implica, necessariamente, no compartilhamento do poder adquirido. Esta 'coparticipação' no poder, especialmente de decisão, não deve ser encarada, por parte da chefia, como cerceamento de sua autonomia em detrimento da expansão da do outro (Campos, 1997). É importante considerar este compartilhamento do poder de decisão quando esta é comum a todos, de forma a possibilitar que aquela pessoa que efetivará o resultado também participe nas discussões e desenvolvimento deste.

Além disso, Mishima et al (1997) consideram a gerência como uma atividade meio, cuja ação central esta posta na articulação, integração e transformação do processo de trabalho. Portanto, cabe à gerência de enfermagem desempenhar a função de mediadora das relações de trabalho, buscando equilíbrio e neutralidade partidária.

É exatamente nas relações interpessoais que são estabelecidas no ambiente de trabalho que pode estar a chave ou o entrave para a reivindicação e implantação de ações promotoras da qualidade de vida no trabalho. Para Campos (1997), o trabalho em saúde assenta-se nas relações interpessoais na maior parte. Quando a chefe dedica seu tempo para ouvir sua equipe e estabelecer relações de igualdade para com esta, ela está fortalecendo os laços, o que irá conferir maior compromisso no momento de atuar em assuntos que a envolvem.

Em estudo sobre a saúde do trabalhador de enfermagem sob a ótica da gerência, Rocha (2003) evidenciou que subordinação e falta de autonomia, em contraponto à relação 
com seus subalternos que ocorre de forma autoritária. Neste sentido, a posição intermediária da gerência de enfermagem na hierarquia hospitalar tende a reforçar a hegemonia existente e a submissão no trabalho.

O excerto demonstra o perfil do enfermeiro que desempenha função gerencial em reproduzir o padrão sofrido pela hierarquia superior junto aos seus subordinados. Deste modo, a gerência deixa de representar o papel articulador entre as relações de interesses e passa a limitar-se a uma relação de submissão, por um lado, e de repressão, por outro - já que aplica na mesma proporção o tratamento recebido.

O bloqueio na comunicação entre a equipe de enfermagem foi um dos aspectos observados por Rocha (2003) dentre outros, que demonstram que a enfermagem, enquanto gerência, ainda não se sente instrumentalizada técnica e organizacionalmente, para dar conta das demandas de saúdedoença originadas pelos trabalhadores de enfermagem.

\subsection{Qualidade de vida no trabalho (QVT)}

Se o trabalho deixou de ser apenas o local de execução de tarefas e passou a ser concebido como um ambiente que pode provocar tanto o adoecimento, quanto o prazer e favorecimento da qualidade de vida, interessa conhecer como a própria Enfermagem pode fazer de seu dia-a-dia uma escalonada para a promoção da qualidade de vida no trabalho, buscando neutralizar as ações advindas dos processos de desgaste. 
Assim, é importante entender que há diferentes abordagens relacionadas à qualidade de vida no trabalho. A expressão "qualidade de vida" (QV) tem sido referida, tanto no momento da vida dos indivíduos em sociedade, como no momento de trabalho, entendendo que estes se constroem mutuamente. Esta afirmação esta pautada no entendimento de que não há como dissociar a vida e o trabalho, bem como não reconhecer a interface do trabalho na QV (Felli, Tronchin, 2005).

No presente estudo, a QVT será abordada segundo referencial de Breilh (1990). É, portanto, tomada como resultante da relação entre processos favoráveis e destrutivos da saúde no ambiente de trabalho.

Nesta concepção, Silva e Massarollo (1998, p. 284) referem que

a qualidade de vida dos trabalhadores de enfermagem, como um grupo social específico, em última instância, resulta das condições existentes entre os aspectos saudáveis e protetores que este grupo desfruta e os aspectos destrutivos de que padece.

A QVT, como resultante de processos que podem favorecê-la ou deteriorá-la, deve ser objeto do gerenciamento em enfermagem. Se QV resulta dos processos vivenciados nos diversos momentos da vida e a QVT dos momentos vivenciados no trabalho que envolve pessoas, trabalho e organização (Rodrigues, 1994), entende-se que sua promoção deve envolver não apenas os membros da equipe de enfermagem, mas a instituição como um todo.

Desta forma, mesmo a QV percebida em nível individual, decorre de uma estrutura articulada no macro contexto, sendo que as ações individuais só alcançam representatividade quando projetadas para o nível coletivo. 
A QVT tem como foco central a organização mais humanizada para, através dela, engendrar uma relação entre capital e trabalho não-conflitante, mas sim cooperativa (Vieira, Hanashiro 1990). A busca pelo equilíbrio das díspares necessidades presentes no ambiente de trabalho só pode ser alcançada quando as partes envolvidas no conflito conseguem traçar um objetivo comum.

Entretanto, as relações estabelecidas entre os níveis hierárquicas nem sempre possibilitam a horizontalidade na comunicação emergindo, assim, a necessidade desta acontecer dentro da própria equipe). Isto por que as abordagens de QVT enfatizam aspectos antagônicos: de um lado, as reivindicações dos trabalhadores priorizando os aspectos de bem-estar e satisfação no trabalho, e de outro, a ênfase nos efeitos da QVT sobre a produção e produtividade, em defesa dos interesses institucionais, que nada mais são que o interesse no capital (Matos, 1999).

Nesta perspectiva, evidencia-se a necessidade de articulação entre a equipe de enfermagem e os enfermeiros que desempenham funções gerenciais, por estes articularem-se bilateralmente e, por constituírem-se em elo entre as partes, possuem mais poder de negociação.

Entretanto, para que possa ser feito algo em prol aos trabalhadores, é necessário estar comprometido efetivamente com estes, enquanto objeto e meio de trabalho indispensável para a concretização do cuidado. 


\subsubsection{A gerência de enfermagem e a QVT}

Como já dito anteriormente, as questões relacionadas a QVT são extremamente vulneráveis àquele que a observa. Portanto, quando maior a proximidade dos indivíduos desta realidade, nos processos de trabalho e de decisão, maiores serão as possibilidades de efetivação de políticas institucionais.

Neste sentido, é importante que a implementação de propostas para a QVT inclua todos os trabalhadores, independente do cargo que ocupam, pois todos sofrem processos de desgaste no ambiente de trabalho.

No contexto hegemônico do paradigma positivista, o trabalho gerencial de enfermagem tem se desenvolvido de forma a reproduzir os interesses institucionais e, para tanto, direciona as atividades desempenhadas pela equipe, desconsiderando, muitas vezes, as implicações para a saúde do trabalhador. Com isso, o trabalho de enfermagem é permeado por relações tradicionais de caráter autoritário e paternalista, onde se percebe uma maior resistência por parte das gerências e chefias quando há necessidade de mudança na estrutura. Esta organização, que tem como princípio a fragmentação das tarefas, acaba por parcelar também as responsabilidades e decisões, concentrando-as no topo da hierarquia (Oliveira, 1997).

O distanciamento imposto pela hierarquização das relações de trabalho gera dois grupos distintos na equipe: um grupo crescentemente insatisfeito com o trabalho, distante das tomadas de decisões e mero 
cumpridor de tarefas; e um segundo grupo, detentor do poder, das decisões, isolado e hegemônico em suas determinações. Esta divisão promove relações hierarquizadas e dificuldades de horizontalidade na comunicação entre chefia e demais membros da equipe, que tem colaborado para o surgimento de angústias e sofrimentos psíquicos nos trabalhadores de enfermagem.

Sobre isso, Dejours (1994) considera que o sofrimento no trabalho é gerado na evidência do bloqueio da relação do trabalhador com a organização do trabalho, uma vez que a energia pulsional não encontrando descarga no exercício das atividades, acumula-se no aparelho psíquico, ocasionando sentimento de desprazer e tensão, que se somatiza, desencadeando palpitações, hipertensão arterial, tremores, suores, parestesias, cãibras, desidratação das mucosas, hiperglicemia, aumento do cortisol sanguíneo, poliúria etc.

Para Lacaz (2000), é inadmissível falar em qualidade do produto sem tocar na qualidade dos ambientes e condições de trabalho. Considera que a democratização das relações sociais nos locais de trabalho também corrobora sobremaneira ao serviço que é prestado. Assim, as limitações hierárquicas impostas pela própria rigidez organizacional entre os diversos grupos de trabalhadores podem ser modificadas a partir da mudança de comportamento (e paradigma) dos enfermeiros e dos demais trabalhadores da equipe.

A função da gerência deve estar imbuída da supervisão das condições físicas e mentais do trabalhador, no momento da interação com o 
objeto, meios e instrumentos de trabalho, assim como suas formas de organização e divisão.

Felli e Tronchin (2005) consideram que a gerência não está voltada apenas para a organização e controle dos processos de trabalho, mas também para a apreensão e satisfação das necessidades de saúde da população, o que requer considerar a democratização das instituições de saúde e a ampliação da autonomia dos sujeitos envolvidos nos processos de cuidado - usuários e trabalhadores.

O reconhecimento da capacidade profissional em exercer suas atividades, preservando a autonomia no desempenho das funções, somado à valorização do ser humano e de sua posição social, como considerado por Vieira e Hanashiro (1990), são alguns dos fatores essenciais que devem ser observados pelos gerentes de enfermagem quanto à promoção da QVT.

Esta análise permite a compreensão de que as necessidades demandadas pela equipe de enfermagem, se correspondidas, corroboram com a promoção da capacidade intelectual que reflete diretamente na melhoria da QV. Seqüencial e concomitantemente, o profissional satisfeito exerce o seu trabalho em melhores condições.

É necessário que o enfermeiro tome os demais trabalhadores da equipe de enfermagem como objeto de seu trabalho, uma vez que eles são o meio para a efetivação da assistência. Isto se justifica pelo fato de o enfermeiro ter a governabilidade para a tomada de decisões que possibilitam a intervenção na realidade de trabalho, de forma a favorecer a potencialização dos processos favoráveis à saúde. 
Rocha (2003), Felli (2002), Silva, Kurcgant, Queiroz (1998), Silva (1996), Vieira e Hanashiro (1990) referem a escassez de acervo científico que aborde o tema QVT e o gerenciamento de enfermagem, bem como a necessidade de se explorar.

Felli e Tronchin (2005) consideram que a promoção e manutenção da QVT é um desafio para os enfermeiros que assumem a gerência e, também, para os trabalhadores de enfermagem, partilhando responsabilidades e dificuldades em um esforço conjunto. Este estudo busca aprofundar o conhecimento sobre promoção da qualidade de vida dos trabalhadores de enfermagem na instituição hospitalar, como uma ação importante no gerenciamento de recursos humanos de enfermagem. 


\section{FUNDAMENTAÇÃO TEÓRICO-METODOLÓGICA}

Para dar conta da intenção deste estudo, buscou-se um referencial de abordagem que permitisse a apreensão de significados atribuídos pelos sujeitos no seu contexto social; superasse os limites da lógica positivista, que se ampara na objetividade quantitativa e racional dos dados. Nesta perspectiva, adotou-se a abordagem qualitativa, no referencial do materialismo histórico-dialético, portanto, fundamentado na determinação social.

Segundo Minayo et al (1994), a pesquisa qualitativa responde questões muito particulares, já que se preocupa, nas ciências sociais, com um nível de realidade que não pode ser quantificado. Ela trabalha com um universo de significados, motivos, aspirações, crenças, valores e atitudes, que correspondem a um aspecto mais profundo das relações, dos processos e dos fenômenos, que não podem ser reduzidos à operacionalização de variáveis.

Na pesquisa qualitativa, a análise da magnitude das variáveis supere a quantificação das mesmas. Deixa-se de valorizar a repetição numérica de determinada variável e passa-se a compreender o significado e a intencionalidade que são atribuídos, na percepção de um ator que constitui e representa um grupo social.

A proposta de entender o contexto de trabalho a partir da visão daqueles que cotidianamente o experimentam, em quais as condições ele se desenvolve e como isso, de alguma forma, determina o processo saúde- 
doença dos atores sociais, implica em ir ao encontro dos sentimentos, experiências, processos sociais individuais e coletivos. Esse mundo de significados das ações e relações humanas, como considera Minayo (1994), aprofunda-se ao lado não perceptível e não captável pelas medidas estatísticas.

O universo de significados traz consigo a subjetividade presente nas determinações sociais que o sujeito sofre ao longo de sua vida. Ainda que seus relatos e experiências sejam singulares e únicos, eles vêem carregados de todo o processo histórico no qual este indivíduo se insere. Ou seja, a atribuição de significados pelo ator social vai além de sua percepção acerca dos mesmos; ela vem embutida de uma contextualização histórica pela qual ele foi influenciado, ainda que não esteja consciente disso.

Desta forma, o fenômeno ou processo social tem que ser entendido nas suas determinações e transformações dadas pelos sujeitos, que compreende uma relação intrínseca de oposição e complementaridade entre o mundo natural e social, entre o pensamento e a base material (Minayo, 1994).

Breilh e Granda (1989), caminham numa linha paralelamente semelhante à proposição de pesquisa social por Minayo (1994), na qual a epidemiologia social ocupa-se com o estudo do processo saúde-doença na sua dimensão social e se defronta com sociedades que estão sujeitas a leis próprias, cuja explicação ultrapassa as possibilidades do método clínico. 
Esta vertente de análise possibilita a visualização da determinação do processo saúde-doença muito além dos fatores intrínsecos individuais. De um modo geral, a saúde é um bem inato; ao nascer, todas suas funções e órgãos funcionam harmonicamente (ou deveriam funcionar, já que não podemos desconsiderar as mutações genéticas e demais alterações que interferem no estado de saúde antes mesmo ou no exato momento do nascimento). Entretanto, devido a fatores internos e externos, este estado real - ou aparente - de saúde, tende a ser afetado, dando lugar ao que se chama de doença (Mininel, 2004)

O modelo médico positivista, hegemônico ainda nos dias atuais, tem se ocupado de analisar o processo saúde doença em seu aspecto individual e particularizado, voltadas para o caráter biológico e restrito. Para a epidemiologia social, fundamentada na teoria da determinação social, a análise da saúde e do processo doença depende, além dos fatores individuais, do modo de como se estrutura a sociedade, a economia, os aspectos jurídicos e o aparato político-ideológico que conformam a dimensão social.

Segundo Breilh e Granda (1989, p.35),

.... objeto de estudo da ciência epidemiológica é a saúdedoença como processo particular de uma sociedade. Isto quer dizer que, ao contrário da clínica, que se concentra em problemas que se manifestam na pessoa como processo individual e aborda intensivamente a dimensão biológica de tais problemas, a epidemiologia recorre principalmente a uma metodologia de caráter extensivo para estudar grandes grupos sociais, explicando determinações mais profundas que operam sobre eles e trazem como conseqüência 0 aparecimento de perfis ou padrões típicos de saúde e doença característicos destes grupos sociais. 
A área da saúde e a teia de relacionamentos sociais que são estabelecidos entre os profissionais, caracteriza-se como um grupo social específico por lidar com a saúde - e, na suma maioria das vezes, com a doença - da sociedade e, de alguma forma, por ser influenciado por este processo no seu próprio perfil de adoecimento.

Para a compreensão do perfil de morbi-mortalidade dos trabalhadores de enfermagem como um grupo social específico inserido na área de prestação de serviços em saúde, é necessário utilizar-se da teoria da determinação social para captar os processos subjetivos que permeiam o contexto social do trabalho e como as relações que são estabelecidas interferem no padrão de saúde desses trabalhadores.

Partindo-se desta premissa, a fundamentação teórica proposta para esta pesquisa, ampara-se nos pressupostos de Breilh e Granda (1989), que propõem um modelo de estudo sistemático na busca científica das determinações que operam sobre a vida social, mediante processos reais. Os autores consideram a análise dos processos estruturais da sociedade, uma vez que estes são a base de desenvolvimento da coletividade, que permitem explicar o desenvolvimento de condições de vidas particulares; o estudo dos perfis de reprodução social (produção e consumo) dos diferentes grupos sócio-econômicos (classes sociais) com as correspondentes potencialidades (bens ou valores de uso) de saúde e sobrevivência, assim como os riscos (contravalores) de adoecer e morrer; e a compreensão integral dos fenômenos biológicos que configuram os 
padrões típicos de saúde-doença dos grupos e dos indivíduos que os compõem (Breilh, Granda, 1989).

A hegemonia do modo de produção capitalista desencadeou uma realidade permanentemente contraditória, onde forças e interesses opostos compõem o cenário de trabalho. Ao mesmo tempo em que o ambiente de trabalho consolida a inserção social do indivíduo e permite o desenvolvimento de suas potencialidades - uma vez que este tipo de participação incide em retorno financeiro ao trabalhador, o que lhe confere acesso ao consumo de bens e serviços e o torna integrante do meio social onde desenvolve suas relações - ele também expõe este indivíduo aos riscos e sujeições implícitos no trabalho, que por sua vez geram desgaste e ocasionam doenças.

Esta contraditoriedade presente no trabalho determina o perfil de saúde-doença do trabalhador que dele participa. Desta forma, não há uma unilateralidade essencialmente benéfica ou maléfica; há uma via dupla onde processos destrutivos e favoráveis se completam, mas não necessariamente de uma forma equânime.

Ademais, não apenas os processos de produção desenvolvem-se no sistema de contravalores; os processos de consumo também são marcados cotidianamente por situações que, num mesmo momento, apresentam-se como potencializadoras da condição de saúde (como quando há o acesso à educação básica e à assistência à saúde) ou deteriorante da mesma (quando este mesmo acesso está bloqueado) (Breilh, Granda, 1989). 
As contradições apresentadas pela realidade devem ser contempladas, uma vez que são determinantes da qualidade de vida daqueles que a vivenciam. O trabalho de enfermagem, por sua vez, igualmente desenvolve-se em ambientes acentuadamente marcados por estes paradoxos, já que seu campo de atuação situa-se no limiar da vida e da morte.

Desta forma, quando se busca compreender os significados e sentimentos dos trabalhadores da equipe de enfermagem, faz-se necessário, indubitavelmente, analisá-los dentro de seu contexto e de suas determinações sociais, em dimensões que compreenda do nível individual ao coletivo e que permitam o desenho do perfil saúde-doença.

Acerca disso, Breilh e Granda (1989) propõem uma separação dos processos e formas de determinação na investigação epidemiológica, devendo esta ser ordenada através da análise: da dimensão estrutural, formada pelos processos de desenvolvimento da capacidade produtiva e das relações sociais, de forma a demonstrar as principais tendências das formas de organização coletiva; da dimensão particular, formada pelos processos ditos de reprodução social, de forma a instrumentalizar a interpretação das ligações entre as mudanças estruturais e suas conseqüências individuais de saúde-doença - que constituem o padrão de vida do grupo; da dimensão individual, formada pelos processos individuais que levam ao adoecimento ou morte ou, ao contrário, sustentam os desenvolvimentos somático e psíquicos. 
A proposição de uma análise das contradições existentes dentro de cada dimensão, permite a identificação dos processos que ocorrem dentro de três esferas distintas, mas complementares. Na mesma linha de pensamento dos autores supracitados (Breilh, Granda, 1898), a primeira esfera, de nível geral, relaciona-se com os macro-aspectos de desenvolvimento coletivo, como o contexto político, as ideologias, a distribuição de renda e poder e a realidade sócio-econômica da sociedade. A segunda esfera, que pode ser considerada como a de desenvolvimento dos grupos sociais específicos que, por sua vez, compõem a esfera de nível geral, caracteriza-se pelas formas de organização e culturais, pelos processos de trabalho, pelos padrões de produção e de consumo, e pela integração das relações que são estabelecidas entre as pessoas (processos individuais) e o grupo social em que se insere (processos coletivos). A terceira e última esfera refere-se aos processos individuais, que se desenvolvem de forma singularizada e subjetiva às duas outras dimensões.

Portanto, quando um indivíduo emite um significado a respeito de um tema qualquer, este significado vem com uma impressão do histórico de vida deste indivíduo até o presente momento, em uma determinada inserção social.

Ou seja, os determinantes do processo saúde-doença deixam de ser dicotomizados (causa e efeito, agente etiológico e doença) e individualizados (doença como conseqüência isolada de um corpo com alterações biológica) e adquirem um caráter coletivo-social (distúrbio individuais causados por determinantes sociais compõem o perfil de adoecimento coletivo) e 
contraditório (os paradoxos existentes entre as relações que são estabelecidas entre os grupos sociais são determinantes da qualidade de vida destes grupos).

Com isso,

estabelece-se a dimensão geral ou estrutural do problema, estudando o modelo sócio-econômico de desenvolvimento com suas forças e formas de produção, para estabelecer, na dimensão particular, as diferentes classes sociais, com seus perfis de produção social (trabalho e consumo) e então definir os problemas e potencialidades mentais de cada classe (Breilh e Granda, 1989, p. 44).

Independente da dimensão de análise, o cenário onde se desenvolvem as relações sociais é composto por fatores que podem colaborar para o desenvolvimento da saúde do indivíduo ou comprometê-la. Porém, o processo de trabalho não é, em si mesmo, puramente benéfico para a saúde ou excessivamente danoso; seus aspectos benéficos e suas facetas destrutivas coexistem e operam de modos distintos, de acordo com o momento histórico e o grupo social em questão (Breilh, 1995).

A coexistência dos aspectos que favorecem a saúde ou a deterioram nem sempre ocorrem sinergicamente. A prevalência dos aspectos favoráveis ao desenvolvimento de saúde desencadeia a melhoria da qualidade de vida; em contrapartida, quando os aspectos deteriorantes predominam, ocorre o aparecimento do desgaste ou da doença. Breilh (1995) prefere empregar o conceito de processo que traduz a dinamicidade da realidade, e falar de processos destrutivos e processos favoráveis ou protetores para referirse ao conjunto de determinantes que condicionam epidemiologicamente o 
trabalhador, seja no espaço produtivo ou no espaço de consumo e a cotidianidade.

Utilizando-se também desta terminologia, a saúde do trabalhador está subordinada aos determinantes sociais presentes não apenas no ambiente de trabalho, mas em todas as dimensões de sua vida. Esta subordinação aos processos determinantes do perfil de saúde-doença, reflete no padrão da condição de saúde desenvolvida por este indivíduo.

Os processos destrutivos e favoráveis ou protetores da saúde presentes no trabalho de enfermagem resultam da inserção histórica e social dos trabalhadores.

O perfil reprodutivo de reprodução social é determinado, portanto, tanto na prevalência dos processos protetores da saúde quanto nos processos destrutivos (também denominado contravalores) a que esta profissão está exposta, sendo que os processos protetores inclinam o indivíduo ao pólo saúde e os processos destrutivos ao pólo doença.

Como não é possível evitar os processos destrutivos, deve-se buscar harmonizá-los de forma que, mesmo diante dos contravalores, o trabalhador consiga desenvolver suas atividades sem prejuízos de sua saúde e qualidade de vida.

Assim, os esforços devem estar voltados à potencialização do desenvolvimento dos processos protetores da saúde, já que são eles que podem amortizar os impactos decorrentes dos processos destrutivos existentes. Nesta perspectiva, deve-se considerar os processos de trabalho 
e as relações que são estabelecidas como determinantes da condição de saúde enquanto indivíduo e dentro do perfil de saúde-doença enquanto coletividade.

O esforço para o conhecimento e defesa da saúde dos trabalhadores deve ancorar propostas que integrem o conjunto de contradições da vida social. Do contrário, perde-se o objetivo de interpretação dos problemas e de elaboração de programas de ação, já que uma visão restritiva e parcial implica em profundas mudanças na vida do trabalhador (Breilh, 1995).

Por acreditar que este referencial teórico permite uma investigação mais aproximada da realidade dialética dos trabalhadores de enfermagem e que a aplicação destes conceitos instrumentaliza a análise dos dados, uma vez que remete as percepções individuais a uma dimensão coletiva, é que adotou-se a Teoria da Determinação Social para nortear o caminho de investigação do processo saúde-doença no ambiente de trabalho da enfermagem.

Este estudo busca recompor os processos favoráveis e destrutivos no momento do trabalho, compondo um perfil que expresse a qualidade de vida dos trabalhadores de enfermagem.

Enquanto os processos favoráveis estão relacionados ao desenvolvimento de potencialidades, podem ser captados pelo significado que o trabalho Ihes atribui.

Para captar os processos destrutivos, é útil a sistematização teóricometodológica proposta por Laurell e Noriega (1989), partindo-se da análise 
do processo de trabalho e de como a produtividade nele se concretiza, expondo o trabalhador às cargas de trabalho e gerando processos de desgaste. 


\section{CAMINHO METODOLÓGICO}

\subsection{Tipo de Estudo}

Este é um estudo realizado, predominantemente, na abordagem qualitativa. Fundamenta-se no referencial teórico-metodológico do materialismo histórico-dialético e na determinação social dos processos saúde-doença. Foi desenvolvido e ancorado nas categorias analíticas: trabalho de enfermagem; processos potencializadores e destrutivos da saúde e perfis saúde-doença do grupo. Os processos destrutivos são analisados na interação do trabalhador com os elementos do processo de trabalho (objeto, meios e instrumentos e formas de organização do trabalho) que são geradores de cargas de trabalho e processos de desgaste.

\subsection{Cenário}

O estudo foi desenvolvido em um hospital universitário da região centro-oeste do País, como previsto no projeto "Monitoramento da saúde do trabalhador de enfermagem: promovendo a qualidade de vida no trabalho", representando um dos cenários. Denominaremos este campo de estudo como "Hospital Universitário de Estudo - HUdE". 
Os critérios de eleição deste hospital foram: a representatividade populacional e profissional da região centro-oeste, a manifestação de interesse do hospital e a autorização da instituição para realização da pesquisa de campo. Além disso, esta Instituição apresenta um serviço de enfermagem peculiar, constituído por diversos vínculos empregatícios, turnos de trabalho diferenciados de acordo com o tipo de contratação e heterogeneidade do corpo de trabalhadores, advindos de vários estados e regiões do Brasil, critérios que justificaram a realização do estudo.

O HUdE está localizado em uma capital da região centro-oeste do país, não identificada devido ao sigilo e confidencialidade garantidos à fonte fornecedora dos dados. A cidade onde está localizado o HUdE possuía, segundo dados do IBGE (2005), 2.333.118 habitantes, distribuídos em uma área territorial de $5.802 \mathrm{~km}^{2}$.

O HUdE é uma instituição sem finalidade lucrativa e integrante do Sistema Único de Saúde (SUS). Foi inaugurado no mês de agosto de 1972, pelo então presidente General Emílio Garrastazu Médici, e era mantido pelo Instituto de Pensão e Aposentadoria dos Servidores do Estado (IPASE). Posteriormente, com a extinção deste órgão, passou a ser mantido pelo Instituto Nacional de Assistência Médica da Previdência Social (INAMPS). Em 1990, no governo Collor, o hospital foi cedido à universidade local e assim permanece até os dias atuais ${ }^{1}$.

Além de ser referência na prestação de serviços de assistência à saúde da população da região nos níveis primário, secundário e terciário, o hospital oferece condições para o desenvolvimento de atividades 
educacionais voltadas à graduação e pós-graduação na área da saúde, buscando integrar as atividades educacionais às atividades docentes assistenciais e apoiar o desenvolvimento de pesquisa e extensão.

Segundo o Regimento Interno do Hospital (2002), as fontes de renda que subsidiam seu funcionamento provêm da remuneração prevista no convênio universitário, Ministério da Educação e Ministério da Saúde, convênio com outras instituições, verbas específicas, repasses, subvenções e donativos ${ }^{2}$

Em uma pesquisa realizada pelo Ministério da Saúde no ano de 2000, e divulgada no próprio site da Instituição, cerca de 960 mil pacientes que utilizaram os hospitais integrantes da rede do Sistema Único de Saúde na cidade, a maior nota foi dada ao $\mathrm{HUdE}$, tanto em relação à equipe de funcionários quanto às instalações locais.

O HUdE conta atualmente com 189 leitos, 121 salas ambulatoriais e $41.170 \mathrm{~m}^{2}$ de área construída. Seu atendimento mensal é, em média, de 36.000 atendimentos, 60.000 exames complementares e 500 intervenções cirúrgicas. Além de receber alunos de graduação dos diferentes cursos fornecidos pela universidade à qual se vincula (como Medicina, Enfermagem, Odontologia, Nutrição, Farmácia, Psicologia, Serviço Social, Administração, Arquitetura e outros), o Hospital também oferece estágios de pós-graduação latu e strictu senso ${ }^{1}$.

A estrutura do HUdE compreende uma área técnico-administrativa e outra com finalidade assistencial e apoio ao ensino e pesquisa, que são

\footnotetext{
${ }^{2}$ Os dados referidos foram obtidos no site do hospital universitário de estudo.
} 
compostas por: Conselho Deliberativo, Diretoria, Conselho TécnicoAdministrativo, Divisões, Clínicas e Áreas, Centros, Serviços e Setores. A Diretoria, por sua vez, é composta por: Diretor, Diretor Adjunto de Serviços Assistenciais, Diretor Adjunto de Assuntos Administrativos, Diretor Adjunto de Apoio ao Ensino e Pesquisa. O planejamento e a execução de atividades assistenciais ocorre por meio das Divisões, Centros, Serviços e Setores subordinados à Diretoria Adjunta de Serviços Assistenciais. Dentre as Divisões vinculadas às atividades assistenciais, está a Divisão de Enfermagem, que planeja, coordena, executa e avalia as atividades assistenciais e administrativas das Clínicas: Médicas, Cirúrgica, Pediatria Clínica, Pediatria Cirúrgica, Centro Cirúrgico, Tratamento Intensivo, Ginecologia e Obstetrícia, Ambulatorial, Cirurgia Ambulatorial, Pronto Atendimento, Hemodiálise, Central de Esterilização, Neonatologia e Apoio Diagnóstico e Terapêutico. O planejamento e a execução de atividades de apoio ao ensino à pesquisa são exercidos pelas Divisões, Comissões e Setores subordinados à Diretoria Adjunta de Ensino e Pesquisa. O planejamento e a execução das atividades administrativas são exercidos pelas Divisões, Centros e Setores Subordinados à Diretoria Adjunta de Assuntos Administrativos ${ }^{1}$.

Este Hospital, caracterizado como de grande porte, possuía em maio de 2006, 2.126 trabalhadores, dos quais $591(27,8 \%)$ pertenciam ao Serviço de Enfermagem, sendo: 83 (14,04\%) enfermeiros, 427 (72,25\%) auxiliares de enfermagem e 81 (13,70\%) auxiliares operacionais de serviços diversos. Esta última categoria subordina-se ao serviço de enfermagem e, mesmo não 
possuindo reconhecimento junto ao COFEn, é institucionalmente reconhecida e integra a equipe de enfermagem na estrutura hierárquica proposta. Entretanto, esta categoria não realiza nenhum cuidado ou qualquer outro procedimento junto ao paciente. Além da participação destes trabalhadores na equipe de enfermagem, outra especificidade encontrada nesta realidade é a não existência de técnicos de enfermagem, junto ao quadro de contratação do hospital, uma vez que esta categoria profissional ainda não possui reconhecimento junto à universidade a que este Hospital pertence ${ }^{1}$.

Há três formas de vinculação dos funcionários junto ao HUdE, sendo: a) contratados sem vínculo empregatício com a Instituição, por meio da fundação da universidade; b) funcionários efetivos da fundação da universidade e; c) funcionários públicos pertencentes e remunerados pelo Ministério da Saúde, porém cedidos ao hospital universitário.

Os trabalhadores de enfermagem efetivos e os contratados pela fundação trabalham 30 horas semanais; os funcionários públicos pertencentes ao Ministério da Saúde trabalham 24 horas semanais.

O referido Hospital possui um setor específico de medicina do trabalho, vinculado à Universidade, que se destina ao atendimento e suporte aos trabalhadores, ligados tanto ao hospital quanto à universidade, nos serviços de homologação de atestados médicos inferior a 30 dias; acompanhamento de exames periódicos; readaptação funcional; exames admissionais e notificações dos acidentes de trabalho. Esta área possui, dentre outros profissionais, um enfermeiro do trabalho, dedicado 
exclusivamente e em período integral para assistência dos trabalhadores. Não são desenvolvidos, neste setor, programas voltados à saúde ou qualidade de vida dos trabalhadores de enfermagem.

A Comissão Interna de Prevenção de Acidentes (CIPA), que desenvolvia atividades voltadas à saúde dos trabalhadores do Hospital, foi extinta pela última gestão da diretoria administrativa, segundo informações coletadas junto ao enfermeiro do Serviço de Segurança e Medicina do Trabalho (SESMT). Até o presente momento, em contato recente realizado junto ao setor, a informação permanece mantida.

Também, no momento da coleta de dados no campo de estudo, foram obtidas informações junto a este mesmo Serviço, de que o HUdE, não é obrigado a realizar o preenchimento da Comunicação de Acidentes de Trabalho (CAT) quando da ocorrência do mesmo. Desta forma, a instituição dispõe de um instrumento de comunicação interna, denominado Comunicações Internas de Acidente de Trabalho (CIAT). A justificativa apresentada para a não notificação dos acidentes de trabalho junto ao Instituto Nacional de Seguridade Social (INSS) ampara-se na forma de contratação dos servidores (regidos pelo Regime Jurídico Único - RJU - e, portanto, pela Lei no. 8.112/90 e não existência de vínculos celetistas) e na Lei $n^{\circ}$. 8.213/91, artigo 22, que refere a notificação do acidente de trabalho por meio do preenchimento do formulário denominado CAT, até o primeiro dia útil seguinte, pelo empregador. Contudo, quando a empresa não remete a informação ao INSS, o próprio acidentado, seus dependentes, a entidade sindical ou o médico que o atendeu podem fazê-lo. Ou seja, não está 
explicitado na referida lei a obrigatoriedade de comunicação por parte da empresa.

\subsection{População de estudo}

A população do estudo foi composta pela totalidade dos trabalhadores de enfermagem da Divisão de Enfermagem do HUdE, nas categorias enfermeiros e auxiliares de enfermagem, que somam 510 trabalhadores.

Participaram do grupo focal 22 sujeitos de ambos os sexos. Inicialmente, a proposta era de que os grupos focais fossem constituídos de no mínimo seis e no máximo doze pessoas, conforme consideram Chiesa e Ciampone (1999). No entanto, para que a média de participantes fosse alcançada, optou-se em convidar um número maior, sem impedir o comprometimento da coleta de dados.

Estes trabalhadores, que voluntariamente se propuseram a participar do estudo, representaram as seguintes unidades do hospital: Pronto Socorro Infantil, Urodinâmica, Cirurgia Pediátrica, Centro de Terapia Intensiva, Unidade de Terapia Intensiva Neonatológica, Medicina do Trabalho, Quimioterapia Ambulatorial, Pediatria, Cirurgia Pediátrica, Clínica Médica, Pronto Atendimento e Divisão de Enfermagem. 


\subsection{Coleta de dados}

5.4.1 - Instrumentos de coleta de dados

Para a captação dos dados foram construídos 3 formulários, conforme também previstos no projeto "Monitoramento da Saúde do Trabalhador de Enfermagem: promovendo a qualidade de vida no trabalho" (Felli, 2004).

O formulário 1 "Caracterização institucional e dos trabalhadores de enfermagem" (anexo II), objetivou a captação dos dados da Instituição e da força de trabalho geral e de enfermagem.

O formulário 2 "Questões norteadoras para a coleta de dados com os trabalhadores de enfermagem no grupo focal" (anexo III) teve por finalidade captar o processo de trabalho na Instituição, as cargas de trabalho as quais os trabalhadores de enfermagem estão expostos, quais os problemas de saúde decorrentes desta exposição e quais as estratégias de prevenção são adotadas para a melhoria das condições de saúde e da QVT.

A técnica de grupo focal foi escolhida para a captação de dados que pudessem complementar e acrescentar informações ao estudo vai de encontro à proposição de Chiesa, Ciampone (1999: 308), na qual

justifica-se a escolha desta estratégia metodológica pela possibilidade de reunir os diferentes atores da prática profissional num espaço de investigação que propicia a reflexão crítica sobre - cotidiano profissional. Ainda enquanto probabilidade metodológica, tal estratégia permite aos pesquisadores observar os pontos consensuais e as divergências, além das diferentes maneiras de superação dos problemas evidenciados nos diferentes campos que compõe o cenário. Neste sentido, além de se configurar em um dos momentos de levantamento de dados da investigação, poderá inclusive constituir-se num espaço de 
formulação de alternativas para alguns problemas levantados e discutidos pelo grupo.

Por isso, os encontros foram filmados para que não somente as falas pudessem ser captadas, mas também toda a dinâmica das discussões e posicionamentos dos participantes - de forma a apreender o mais próximo as sensações e percepções colocadas. As autoras citadas (Chiesa, Ciampone, 1999) pontuam que o uso da filmagem permite reter vários aspectos do universo pesquisado, uma vez que esta técnica de documentação lida com planos da comunicação e da imagem.

Outro instrumento utilizado foi a enquête coletiva (anexo IV) que apoiou o registro dos dados pelos sujeitos do grupo focal (Felli, 2004). As enquêtes tiveram por finalidade captar o processo de trabalho e as cargas às quais os trabalhadores de enfermagem estão expostos.

\subsection{2 - Procedimento de coleta de dados}

Inicialmente o projeto "Monitoramento da saúde do trabalhador de enfermagem: promovendo a qualidade de vida no trabalho" foi submetido e aprovado pelo Comitê de Ética e Pesquisa da Escola de Enfermagem da Universidade de São Paulo (anexo I). Foi, também, submetido e aprovado pelo Comitê de Ética e Pesquisa do Hospital Universitário campo de pesquisa, que viabilizou a coleta de dados em campo.

A coleta de dados foi realizada em quatro fases, no período de abril a outubro de 2006. A primeira fase foi composta pelo preenchimento, por parte 
da Divisão de Enfermagem do HUdE, de dois formulários (anexos II e III), referentes à caracterização da Instituição e dos trabalhadores. Após autorização da Instituição, teve início o preparo para a coleta de dados, quando foi designado um enfermeiro para acompanhamento o estudo, a continuidade do processo.

Após o detalhamento da finalidade do projeto, dos objetivos e método para coleta dos dados,foi dado início às negociações para a realização das fases dois e três, realizadas em campo.

A segunda fase foi constituída pelo levantamento dos dados de acidentes de trabalho, ocorridos nos anos de 2004 e 2005, junto ao Serviço de Segurança e Medicina do Trabalho do HUdE, realizada no próprio local de estudo, no mês de maio de 2006. O acesso aos dados de acidentes de trabalho foi obtido junto ao SESMT do Hospital, sob coordenação do enfermeiro do trabalho, que disponibilizou as fichas preenchidas (CIATs) nos anos solicitados. Para a captação dos dados, cada ficha foi analisada individualmente, focalizando-se as seguintes informações: a) tipo de acidente de trabalho; b) profissional que sofreu o acidente; c) local onde aconteceu o acidente; e d) se o trabalhador utilizava ou não os EPIs no momento do acidente.

As CIATs apresentaram variações quanto às informações contidas, sendo que algumas estavam preenchidas em quase sua totalidade, enquanto outras continham apenas alguns dados. De qualquer forma, essas diferenças não comprometeram a captação dos dados, uma vez que os 
critérios selecionados para análise estavam preenchidos indistintamente em todos os instrumentos pesquisados.

A terceira fase ocorreu com a realização dos grupos focais. Para isso, o enfermeiro designado auxiliou na constituição do grupo focal, segundo critérios estabelecidos pela pesquisadora. Estes critérios foram: a) ser composto por trabalhadores da área de enfermagem (enfermeiro, técnico ou auxiliar de enfermagem); b) estes trabalhadores deveriam pertencer ao quadro de contratação do hospital, independente do vínculo empregatício (contratado, efetivo, designado); c) conter trabalhadores de ambos os sexos; d) conter trabalhadores de diversas faixas etárias; e) heterogeneidade de departamentos e unidades clínicas assistenciais; f) diversidade de cargos, funções, atribuições e turnos de trabalho; e g) interesse e voluntariedade na participação.

De posse de tais definições, o enfermeiro encarregou-se de estender o convite aos trabalhadores das diversas unidades do Hospital. A data acordada para a realização da coleta de dados no local de estudo foi na terceira semana do mês de maio do ano de 2006. Foi estabelecido um cronograma das atividades a serem realizadas no período, de forma a sistematizar a coleta e interferir o mínimo possível na rotina de trabalho dos participantes. Este cronograma foi enviado e aprovado pelo enfermeiro responsável pelo projeto junto ao hospital. Assim, nesta fase foi realizada a coleta de dados no grupo focal já composto com trabalhadores das diversas categorias e áreas de enfermagem. 
Segundo Minayo (1994), a técnica de grupo focal prevê a participação de um coordenador e um observador. Para o desempenho da função de coordenador, a própria pesquisadora responsabilizou-se em exercê-lo. Diante da dificuldade de ter um observador treinado no local da coleta e pelo fato do campo de pesquisar localizar-se aproximadamente $1000 \mathrm{Km}$ da capital São Paulo, foi necessária a utilização de filmagem sob consentimento dos sujeitos do grupo.

Ocorreram, nesta fase, três encontros com o grupo focal, num período de uma semana no mês de maio. Os grupos focais foram compostos por trabalhadores de enfermagem, das categorias profissionais enfermeiros e auxiliares de enfermagem, de diversas unidades do hospital, sendo preservada a voluntariedade para a participação das reuniões. Os três encontros com o grupo focal foram direcionados por questões norteadoras constantes do anexo V.

A quarta fase foi caracterizada por um último encontro com o grupo focal, realizado no mês de outubro de 2006, com a finalidade de realizar uma devolutiva dos dados captados anteriormente e discutir possíveis ações voltadas ao favorecimento da saúde e qualidade de vida no trabalho, no âmbito do gerenciamento em enfermagem. Este encontro foi composto pelos mesmos trabalhadores que participaram da terceira fase da coleta de dados.

O início da terceira e quarta fase da coleta de dados, no segundo dia do cronograma, foi marcado pela restrita participação de seis trabalhadores de enfermagem. $O$ não comparecimento dos trabalhadores não ficou foi justificado por vários motivos Devido à relevância do tema reconhecida por 
parte dos participantes, a enfermeira da Divisão solicitou para que aguardássemos uma nova convocação do grupo de trabalhadores inicialmente contatados. Assim, o grupo (em sua maioria composto por enfermeiros chefes de unidades) unanimente solicitou à pesquisadora que as atividades começassem no dia subseqüente, de forma que mais profissionais pudessem participar daquela discussão, que consideram de grande importância.

Assim, o segundo dia de atividades não cumpriu com o cronograma proposto, mas permitiu uma discussão informal sobre processo de trabalho, dinâmica de turnos, importância da pesquisa científica e outros assuntos que espontaneamente emergiram com o grupo que permaneceu no local. Neste dia ainda, todos os participantes do grupo focal preencheram o Termo de Consentimento Livre e Esclarecido (TCLE) específico para o projeto (anexo VI), em conformidade com os preceitos éticos estabelecidos pela Resolução 196/96 do CNS.

O terceiro dia, apesar do atraso, contou com treze trabalhadores vindos das diversas áreas do Hospital. Foi dado início às explicações sobre os objetivos do estudo, a justificativa para a realização da filmagem e a confidencialidade dos dados e anonimato dos participantes. Na seqüência, foram preenchidos os TCLE pelos demais participantes.

Este primeiro momento da coleta de dados com o grupo focal (terceira fase) foi marcado pela discussão do processo de trabalho em enfermagem, direcionada pelas questões norteadoras. Ao término da discussão, foram entregues as enquêtes coletivas para preenchimento da primeira página 
(relacionada ao processo de trabalho em enfermagem) e validação do conteúdo discutido.

O quarto dia do cronograma semanal ajustado (terceira e quarta fases) foram discutidos os conceitos teóricos de processos destrutivos, cargas de trabalho e processos de desgaste. Contou com a participação de dez trabalhadores. Posterior à conceituação, foi aberta a discussão para quais cargas de trabalho os trabalhadores de enfermagem estavam expostos e como estas cargas desencadearam o processo de desgaste. Novamente, ao término das considerações foram retomadas as enquêtes coletivas para preenchimento das cargas de trabalho às quais o trabalhador se expõe.

O quinto e último dia de coleta de dados (terceira e quarta fases) contou com a participação de nove trabalhadores. Os temas propostos para discussão foram a concepção de qualidade de vida, identificação dos processos potencializadores da saúde e possíveis ações direcionadas à promoção da qualidade de vida no trabalho. Assim, foi dado início à abordagem teórica dos temas propostos, seguido pela discussão dos assuntos apresentados. Ao término, foram recolhidas as enquêtes coletivas que estavam de posse dos participantes, uma vez que, para o preenchimento das cargas de trabalho, deveriam discutir com a equipe de trabalho.

A quarta fase foi realizada aproximadamente cinco meses após o término da fase anterior. Este intervalo de tempo foi necessário para que se procedesse à transcrição das falas e análise dos dados. Assim, o quarto 
momento objetivou a realização de uma devolutiva dos dados coletados nos quatro primeiros momentos, para os participantes do grupo focal, e um momento para discussão de possíveis intervenções na realidade, baseandose nos dados anteriormente coletados. Este momento foi acordado e mantido pelo enfermeiro que acompanhou o estudo.

Este encontro contou com a participação de nove trabalhadores e com um cenário que, mesmo apresentando-se acentuadamente inapropriado para a discussão, acabou por desencadear um diferente espectro de análise pela pesquisadora. O hospital estava passando por um cenário de transição de chefia na Divisão de Enfermagem; nos dias antecedentes à quinta fase de coleta de dados; uma nova enfermeira havia sido empossada para o cargo de chefia na Divisão de Enfermagem.

Isoladamente, este fato já representa uma ruptura da rotina de trabalho, bem como do processo de gerenciamento dos serviços de enfermagem, já que leva algum tempo para adaptação às novas rotinas e atribuições. Somado a esta variável, cabe ressaltar que esta transição não ocorreu devido à mudança de diretoria hospitalar, mas por uma articulação de alguns enfermeiros que, em contato com a então diretora concordou em 'passar o cargo' para uma outra enfermeira, pertencente ao quadro de docentes da universidade.

Assim, tanto a enfermeira que havia ocupado o cargo na Divisão de Enfermagem (e participado dos três primeiros encontros deste estudo) quanto à nova enfermeira recém-empossada, participaram das discussões. 
Estas mudanças refletiram nos resultados das proposições de análise do dia, como será descrito na análise e discussão dos dados.

Os quatro encontros realizados com o grupo focal, nos meses de maio e outubro, tiveram uma média de participação de 10 sujeitos e a duração entre 1 hora e 30 minutos e 2 horas, distribuídas entre a conceituação, apresentação dos temas e as discussões.

\subsection{Tratamento dos dados}

Os dados coletados por meio dos instrumentos previamente enviados à Divisão de Enfermagem (Formulários 1 e 2 ) foram analisados quantitativamente nas questões relacionadas ao número de leitos, de atendimentos, total de trabalhadores e número de trabalhadores de enfermagem (segundo as categorias). Dos demais dados foram extraídas as informações relevantes que, de forma fidedigna ao descrito no papel, foram analisadas qualitativamente.

Em relação aos acidentes de trabalho nos anos de 2004 e 2005, os dados coletados foram analisados quantitativamente, sendo subdivididos em: a) número total de acidentes de trabalho, nos anos de 2004 e 2005; b) relação entre o número total de acidentes de trabalho e o número de acidentes de trabalho na enfermagem, nos anos de 2004 e 2005; c) número total de acidentes de trabalho na enfermagem em relação ao número de acidentes de trabalho por categoria profissional (enfermeiros, técnicos e 
auxiliares de enfermagem e estudantes ou estagiários de enfermagem), nos anos de 2004 e 2005.

Quanto aos acidentes de trabalho ocorridos com profissionais de enfermagem, para a obtenção da relação entre os acidentes de trabalhos de enfermagem e o número total de trabalhadores de enfermagem, aplicou-se o indicador de perfil de morbidade, proposto por Cruz (2006).

Os dados captados pela enquête coletiva foram inicialmente transcritos em Planilha Excel e, posteriormente, sofreram o processo de análise temática. Após esse processo foram apresentados em quadros.. Para que a compreensão do significado atribuído a cada resposta da enquête coletiva permitisse a avaliação mais aproximada da realidade, os registros dos sujeitos foram integralmente preservados em sua forma.

Os dados captados com a realização do grupo focal foram parcialmente transcritos, uma vez que os quatro encontros resultaram em, aproximadamente, 6 horas de gravação. Assim, as falas relacionadas ao objeto de estudo e que se referiam às proposições de discussão para o encontro foram transcritas integralmente, com a manutenção das incorreções gramaticais e marcas de oralidade, visando não descaracterizar o conteúdo.

De forma a cumprir a anonimato dos participantes do grupo focal (conforme disposto no TCLE, assinado bilateralmente), os nomes dos sujeitos foram substituídos por nomes de compositores de música clássica, sendo que o único vínculo estabelecido entre o nome real e o fictício é a 
letra inicial. Os nomes fictícios não representam necessariamente o sexo dos participantes.

Após a transcrição das falas, foi realizada a leitura flutuante do conteúdo, que consiste na realização de uma leitura extensiva do material até a impregnação do mesmo. Assim, a análise temática desenvolveu-se na tentativa de captar os "núcleos dos sentidos" contidos nas falas, cuja presença ou freqüência tem algum significado importante para os sujeitos que vivenciam determinadas circunstâncias presentes no dia-a-dia (Minayo, 1994).

Foi realizada a análise temática, sendo que os temas que emergiram das falas foram agrupados nas seguintes categorias: qualidade de vida no trabalho; processos potencializadores à saúde; processos destrutivos à saúde; ações de enfermagem que favorecem ou comprometem a qualidade de vida no trabalho; expectativas e propostas do grupo.

É importante ressaltar que os dados foram captados por metodologias distintas, ora mediante a consulta de dados, ora pelo preenchimento de instrumentos, ora pelas falas no grupo focal, indicando a triangulação de dados coletados.

Após a segregação das relevâncias contidas nos dados em categorias e, dentro dessas, em unidades temáticas, a interpretação foi fundamentada nos pressupostos teóricos de Breilh e Granda (1989), referentes à presença de fatores favoráveis e contravalores presentes no cotidiano de trabalho e que, de alguma forma, determinam o perfil saúdedoença do grupo. 
Assim, a análise dos dados não foi realizada aprofundando-se nas dimensões particular e individual propostas por Breilh e Granda (1989), sem desconsiderar a dimensão estrutural. Buscou-se apreender como se desenvolve a qualidade de vida no trabalho desta realidade e como o gerenciamento em enfermagem pode ser instituinte de inovações no sentido de melhorá-la. 


\section{ANÁLISE E DISCUSSÃO DOS DADOS}

Para a análise dos dados já sistematizados foram considerados os dados quantitativos (dados captados pelos formulários 1 e 2 e os acidentes de trabalho) e os dados qualitativos (enquêtes coletivas e as falas gravadas nos encontros dos grupos focais).

A apresentação e a análise dos dados será feita conjuntamente para sua melhor visualização e discussão.

A análise dos dados obedecerá a seguinte ordem dos temas: a) descrição do perfil da população de estudo; b) acidentes de trabalho; c) processo de trabalho; d) qualidade de vida no trabalho; e) processos favoráveis ou potencializadores da saúde; f) processos destrutivos ou deteriorantes da saúde; e g) busca de intervenções na realidade.

\subsection{Perfil dos sujeitos de estudo}

Como descrito no momento da coleta e tratamento dos dados, a população de estudo foi constituída por 22 trabalhadores das diversas categorias de enfermagem, pertencentes ao Hospital. Para conhecer o perfil dos sujeitos que participaram voluntariamente da pesquisa, as 
características serão analisadas segundo: a) categoria profissional; b) sexo; c) idade; d) local de trabalho; e) tempo de atuação na instituição.

Ressalta-se que, em relação à categoria profissional, o técnico de enfermagem não possui reconhecimento junto ao quadro de contratação da universidade. Devido a isso, os trabalhadores subdividem-se entre enfermeiros e auxiliares de enfermagem e, mesmo quando há o trabalhador com formação de nível técnico trabalhando na Instituição, este é contratado como auxiliar de enfermagem.

A composição desta força de trabalho segundo as categorias é de $14 \%$ enfermeiros e $86 \%$ auxiliares e técnicos.

De acordo com o sexo, o grupo apresentou um número superior de mulheres, característica peculiar da profissão, sendo 16 mulheres e 6 homens. Segundo Almeida e Rocha (1997:18), “a enfermagem é uma ação ou uma atividade realizada predominantemente por mulheres que precisam dela para reproduzir sua própria existência".

Das 16 mulheres, 7 eram enfermeiras e 9 auxiliares de enfermagem; quanto ao sexo masculino, o número entre enfermeiros e auxiliares de enfermagem por sexo foi o mesmo: 3 trabalhadores para cada categoria. Apesar da universidade conter em seu quadro de vinculação profissional a categoria Auxiliar Operacional de Serviços Diversos que se subordina à enfermagem, não houve a participação de nenhum trabalhador com este perfil, uma vez que não há o reconhecimento desta categoria junto ao COFEn. 
Os participantes do grupo focal, segundo as categorias, estavam locados em diferentes setores do hospital, sendo: a) Pediatria Cirúrgica: 2 enfermeiros e 2 auxiliares de enfermagem; b) Unidade de Convênio: 2 auxiliares de enfermagem; c) Pronto Atendimento e Urodinâmica: 1 enfermeiro; d) Quimioterapia Ambulatorial: 1 enfermeiro e 1 auxiliar de enfermagem; e) Serviço de Segurança e Medicina do Trabalho: 1 enfermeiro do trabalho; f) Centro de Terapia Intensiva: 1 enfermeiro e 3 auxiliares de enfermagem; g) Educação Continuada: 1 enfermeiro; h) Clínica Médica: 1 enfermeiro; i) Pediatria Clínica: 1 auxiliar de enfermagem; j) Clínica Cirúrgica: 1 auxiliar de enfermagem; k) Unidade de Terapia Intensiva Neonatológica: 1 auxiliar de enfermagem; I) Divisão de Enfermagem: 2 enfermeiros ${ }^{3}$.

Apesar de os participantes não representarem todas as unidades existentes no HUdE, a maioria deles já havia rodiziado em diversos setores, o que fez com que as vivências de outras realidades que não estavam ali representadas fossem trazidos à discussão por estes trabalhadores.

3 Devido à mudança de chefia na Divisão de Enfermagem no intervalo de tempo transcorrido entre a o primeiro e o último momento de coleta de dados, houve a participação de um enfermeiro que ocupava a chefia de enfermagem no primeiro momento da coleta de dados e, no último momento, estava alocado no Centro de Terapia Intensiva (sua unidade de origem) e a participação de um outro enfermeiro no último momento, recém empossado, que não havia participado das atividades do primeiro momento, pois desenvolvia suas atividades na universidade, junto ao corpo docente. 
A idade dos participantes oscilou entre 20 e 60 anos de idade, assim como o tempo de trabalho, que ficou entre 30 dias e 30 anos. Contudo, este tempo refere-se ao tempo de trabalho enquanto profissional no hospital de estudo e não necessariamente na unidade assistencial que cada um representou no momento da coleta de dados, visto que há uma rotatividade interna entre as unidades assistenciais, de acordo com motivos diversos (necessidade de pessoal, alteração de turno de trabalho, solicitação por parte do próprio trabalhador ou outras).

A variação etária e as diferenças entre o tempo de experiência profissional em muito colaboraram para a discussão dos temas propostos, já que o impacto dos desgastes do trabalho, sentido pelos trabalhadores com maior tempo de profissão, ainda não era percebido pelos recém-chegados, bem como o entusiasmo entre ambos era diferente. Grande parte dos sujeitos possuía tempo igual ou superior a 10 anos de trabalho, o que conferiu grande credibilidade às falas relacionadas ao processo de trabalho, já que estes trabalhadores possuíam vivência suficiente para retratar a realidade experenciada.

\subsection{Acidentes de trabalho}

O HUdE possui, junto ao SESMT, os registros relacionados aos acidentes de trabalho com os diversos trabalhadores do Hospital. O recorte para análise é referente ao período de dois anos. 
No ano de 2004, o Hospital apresentou 49 notificações de acidentes de trabalho, dos quais 25 deles (51\%) ocorreram com trabalhadores de enfermagem. Dos 25 acidentes 16 (64\%) ocorreram com auxiliares de enfermagem, 6 (24\%) com alunos e estagiários de enfermagem, 2 (8\%) com enfermeiros e 1 (4\%) com técnico de enfermagem. Há uma inconsistência em relação ao dado referente ao técnico de enfermagem, uma vez que, por esta categoria profissional não possuir reconhecimento junto ao quadro de contratação da universidade, possivelmente este registro esteja se referindo a um auxiliar de enfermagem. Ou seja, ainda que ele tenha o nível técnico seu vínculo contratual é de auxiliar e, portanto, deve ser considerado como este.

No ano de 2005, o Hospital apresentou 73 notificações de acidentes de trabalho, dos quais 19 deles (26\%) ocorreram com profissionais de enfermagem. Dos 19 acidentes ocorridos com profissionais da equipe de enfermagem, 8 (42\%) foram com alunos e estagiários de enfermagem, 6 (32\%) com técnicos de enfermagem; 4 (21\%) com auxiliares de enfermagem e $1(5 \%)$ com enfermeiro. Novamente, os dados apresentaram a inconsistência referente aos técnicos de enfermagem.

Pode-se observar, no segundo ano de análise, um aumento em 49\% das notificações realizadas. Como não foi obtido o dado referente ao total de trabalhadores referentes a cada ano (e sim o número total referente ao ano de 2006), não é possível estabelecer relação entre este percentual e o aumento em relação ao total de trabalhadores expostos. Entretanto, ainda que se considere um aumento dos expostos nos dois anos, não seria o 
suficiente para justificar o aumento dos acidentes. Este número pode ser devido a um aumento real no número de acidentes, causado por motivos diversos, ou pode representar uma redução do número de subnotificações, devido à atuação mais expressiva da Educação Continuada, conforme relatado pelo próprio profissional responsável pela área de enfermagem do trabalho.

Outro fator que chama atenção é a redução proporcional dos acidentes com trabalhadores de enfermagem, em relação ao total de acidentes. No primeiro ano de análise, a enfermagem representou, sozinha, $51 \%$ dos acidentes ocorridos no Hospital. Mesmo sendo uma categoria bastante expressiva (aproximadamente 27\% da força de trabalho em 2006), a representatividade dos trabalhadores de enfermagem na composição dos acidentes de trabalho é relevante.

No segundo ano de análise, partindo da mesma premissa de análise, ou seja, de que o número total de trabalhadores em 2006 representa o mesmo número de 2005, a representatividade da enfermagem nos acidentes de trabalho cai acentuadamente. A categoria passa a se responsabilizar por $26 \%$ dos acidentes ocorridos ( $25 \%$ a menos em relação ao ano anterior), sendo a representatividade destes acidentes para a massa de trabalhadores de enfermagem exposta menor do que o ano anterior.

Em relação à participação das categorias da equipe de enfermagem, emergem algumas justificativas que precedem à discussão dos dados encontrados. Devido ao fato do técnico de enfermagem não ser reconhecido junto ao quadro de contratação da universidade, as notificações de 
acidentes de trabalho junto a esta categoria será considerada como pertencente aos auxiliares de enfermagem. Assim, os auxiliares de enfermagem são os que apresentam maior ocorrência de acidentes de trabalho. Contudo, este dado não é proporcional à representatividade desta categoria, que representa $72 \%$ da força de trabalho na equipe de enfermagem.

Outro fato que merece atenção é o número de acidentes de trabalho com alunos e estagiários de enfermagem nos dois anos. A justificativa para tal acontecimento pode ser o fato de, por estarem em período de aprendizagem prática das ações, a insegurança e inexperiência poderiam colaborar com este percentual. Outra hipótese seria a de, por estarem sob supervisão contínua de professores, a comunicação do acidente seria incentivado (quando não compulsório) pela supervisora. No entanto, estudos como de Barachatti e Felli (2005), Scudeler e Felli (2006), em outra realidade, identificaram a grande freqüência de exposição de graduandos aos fluidos corpóreos (carga biológica) e substâncias químicas (carga química), respectivamente. Este dado é preocupante, uma vez que verificase a exposição aos processos de desgaste, que antecede à inserção formal no mercado de trabalho, em decorrência do processo de ensinoaprendizagem.

Dentre as causas dos acidentes de trabalho notificadas nos dois anos analisados, em percentuais aproximados, apareceram: no primeiro ano $80 \%$ se devem aos acidentes com pérfuro-cortantes e $8 \%$ com acidentes exposicionais (pela exposição de cargas biológicas ou químicas). No 
segundo ano, os acidentes com perfuro-cortantes representaram $85 \%$ do total de notificações, seguido pelas quedas, representada por $10 \%$ dos acidentes.

Balsamo, Felli (2006); Canini, Gir, Hayashida, Machado (2002) e Silva (1996), encontraram o maior número de acidentes de trabalho junto aos auxiliares de enfermagem que, novamente, também representaram a categoria com maior risco nos estudos. Isto permite algumas reflexões acerca do papel que o auxiliar de enfermagem tem representado na equipe, uma vez que assumem a 'linha de frente' junto aos pacientes; ou seja, são estes trabalhadores que mantém o contato mais próximo e contínuo na assistência aos pacientes e familiares e, portanto, estão mais expostos à alguns tipos de cargas. Em estudo sobre o desgaste apresentado por auxiliares de enfermagem, Siqueira, Watanabe, Ventola (1995) evidenciaram como riscos inerentes às tarefas executadas pelos auxiliares, o grau de instrução relativamente baixo e o pouco conhecimento dos fatores de risco e métodos de prevenção.

Balsamo e Felli (2006); Canini, Gir, Machado (2005); Silva (1996), encontraram como principais causas notificadas de acidentes de trabalho os ocorridos com materiais pérfuro-cortantes. Canini, Gir, Hayashida, Machado (2002) evidenciaram que a maioria dos acidentes de trabalho com pérfurocortantes ocorre com a equipe de enfermagem. Marziale, Nishimura, Ferreira (2004) colocam que estes acidentes apresentam, como causa principal, o manuseio de agulhas e cateteres. 
Os resultados apresentados permitem a apreensão da existência da subnotificação de acidentes no ambiente de trabalho, percepção confirmada posteriormente pelos participantes do grupo focal, que relataram "ter conhecimento sobre os acidentes de trabalho que não são notificados, porque os próprios trabalhadores acidentados contam o que aconteceu e o porquê optaram pela não notificação". Esta justificativa da não notificação do acidente, na maioria das vezes, deve-se ao fato de os trabalhadores não considerarem importante o evento acidente, ou por falta de tempo, ou por não acreditarem que podem ser infectados com alguma doença. Napoleão, Robazzi, Marziale, Hayashida (2000), pesquisando sobre o assunto, encontraram que a desinformação quantos aos riscos dos acidentes de trabalho foi a causa principal para a subnotificação. Silva (1996) evidenciou que, pelo fato dos acidentes serem aparentemente de pouca gravidade, os trabalhadores não notificavam a ocorrência dos mesmos.

Como conseqüência das condições inseguras de trabalho em instituições hospitalares, são freqüentes os acidentes de trabalho, o absenteísmo e os afastamentos por doenças na equipe de enfermagem, o que tem dificultado a organização do trabalho em diversos setores e, conseqüentemente, a qualidade da assistência de enfermagem prestada (Barboza, Soler 2003). O absenteísmo e as licenças e afastamentos por acidentes de trabalho geram um efeito dominó sobre a equipe de enfermagem, já que a ausência de um trabalhador implica em sobrecarga para o outro que, irremediavelmente, adoecerá em período posterior. 
Até o momento da coleta de dados, a CAT não era compulsória entre os trabalhadores do HUdE, já que estes não possuem vínculo celetista junto à Instituição, mas enquadram-se como servidores públicos federais portanto, desobrigados ao cumprimento das regulamentações disposta na CLT. Entretanto, em 06 de outubro deste ano, foi disposta a Portaria $\mathrm{n}^{\circ}$. 1.675 que institui, em seu artigo $1^{\circ}$, o Manual para os Serviços de Saúde dos Servidores Civis Federais, apresentando normas e critérios para uniformização de condutas no âmbito do serviço de saúde. Esta portaria dispõe, dentre outros, sobre a notificação do acidente de trabalho, mediante o preenchimento da Comunicação de Acidente de Serviço (CAS) junto à chefia do setor de trabalho e, também institui, no âmbito da enfermagem, atribuições relacionadas a programas de promoção da saúde dos servidores.

Em contato realizado junto ao SESMT do HUdE sobre o impacto desta nova portaria junto às normas realizadas pelo hospital, foi informado que o Hospital está atento à tal prerrogativa e disposto à implementá-la.

\subsection{Processo de trabalho em enfermagem}

Para a reconstrução do processo de trabalho em Enfermagem no HUdE, os dados coletados foram analisados segundo elementos componentes do processo de trabalho propostos por Marx (1982) e Silva (1996). Marx (1982) consideram como 
constituintes do processo de trabalho: a) a matéria a que se aplica o trabalho, o objeto de trabalho; b) os meios de trabalho, c) o próprio trabalho. Silva (1996), utilizando-se do referencial marxista, decompõe o processo de trabalho de enfermagem em objeto, meios / instrumentos de trabalho e formas de organização do trabalho, entendidas como a teia em que atividades são operadas.

O HUdE desenvolve atividades assistenciais e de ensino e pesquisa, sendo as atividades realizadas neste local direcionadas a estes três ramos de atuação. O processo de trabalho no Hospital é, então, decomposto em objeto, meios e instrumentos e formas de organização do trabalho, de forma a recompor o trabalho vivenciado pelos trabalhadores que o compõe.

\subsubsection{Objeto de trabalho}

O objeto de trabalho dos diferenciados trabalhadores do Hospital foi recomposto a partir das atividades desenvolvidas por estes profissionais, como se pode observar no quadro 1. 
Quadro I: Percepções dos trabalhadores de enfermagem quando às atividades realizadas no ambiente de trabalho HUdE, 2006.

\begin{tabular}{|l|l|}
\hline \multicolumn{1}{|c|}{ Atividades desenvolvidas no HUdE } & $\begin{array}{c}\text { Objeto de trabalho (captados a } \\
\text { partir das atividades relacionadas } \\
\text { ao lado) }\end{array}$ \\
\hline $\begin{array}{l}\text { Procedimentos invasivos; } \\
\text { Administração e manipulação de medicamentos; } \\
\text { Assistência e cuidado aos pacientes; }\end{array}$ & Paciente \\
Acompanhamento de pacientes na realização de exames & \\
Realização de procedimentos de alta complexidade, & \\
\hline Assistência e cuidado aos familiares & Familiares \\
\hline $\begin{array}{l}\text { Supervisão da assistência de enfermagem a pacientes críticos; } \\
\text { Supervisão sobre materiais e equipamentos; } \\
\text { Consultas de enfermagem nos trabalhadores do hospital; } \\
\text { Registro dos acidentes de trabalho; } \\
\text { Visita aos locais de trabalho para concessão de insalubridade }\end{array}$ & \\
\hline
\end{tabular}


A partir das atividades desenvolvidas no HUdE, pode-se definir distintos objetos de trabalho, sobre os quais os trabalhadores atuam diariamente: o paciente e seus familiares e os próprios trabalhadores de enfermagem. As atividades assistenciais direcionam-se aos pacientes e familiares e/ou à comunidade; as atividades gerenciais são desenvolvidas tomando os trabalhadores de enfermagem como objeto de trabalho dos enfermeiros, que desempenham funções gerenciais.

Apesar de não ter sido realizada a contextualização do objeto de trabalho enquanto marco referencial proposto por Marx (1982), o aparecimento do mesmo como alvo para onde as atividades estão direcionadas permitiu uma abordagem direcionada à finalidade do trabalho $\mathrm{e}$ a essencialidade do objeto de trabalho para o desenvolvimento da profissão.

Silva (1996), utilizando-se dos pressupostos de Marx (1982), coloca que frente à finalidade de organizar a assistência para favorecer o processo de cuidar, a transformação operada no processo de trabalho gerencial incide, prioritariamente, sobre os trabalhadores, enquanto objeto de trabalho. Nesta abordagem e de acordo com as falas identificadas, podese apreender a relevância atribuída aos trabalhadores de enfermagem, uma vez que grande parte das atividades citadas compõe o rol de atribuições do enfermeiro no gerenciamento das atividades.

Mesmo sendo identificados dois objetos de trabalho dentre as falas colocadas pelos próprios trabalhadores do Hospital, a tônica deste trabalho é o próprio trabalhador de enfermagem como objeto de trabalho, no processo de trabalho gerencial. Assim como colocado por Silva (1996) no 
excerto supra referido, quando a análise volta-se para a organização da assistência objetivando-se a efetivação do cuidado, a atenção deixa de ser direcionada diretamente ao paciente e transfere-se ao trabalhador de enfermagem - que passa a se constituir objeto de trabalho dos enfermeiros que coordenam as atividades gerenciais. Por outro lado, é meio de trabalho para concretização do cuidado, quando o objeto é o paciente. Nesta perspectiva, enfatiza-se o papel do enfermeiro no gerenciamento frente às necessidades dos demais trabalhadores da área.

O objeto de trabalho são todas as coisas que são transformadas no processo de trabalho, orientadas por uma finalidade (Silva, 1996). Esta transformação não necessariamente ocorre fisicamente, uma vez que está permeada pela subjetividade, mas, muitas vezes, em alguma mudanças nas condições e percepções deste objeto.

\subsubsection{Meios e instrumentos de trabalho}

Os meios e instrumentos de trabalho foram analisados tanto para a atividade assistencial quanto para a gerencial, sendo a interpretação direcionada aos diferentes objetos de trabalho, como se pode observar no quadro a seguir: 
Quadro II: Percepções dos trabalhadores de enfermagem quando aos meios e instrumentos utilizados para a prestação da assistência de enfermagem no ambiente de trabalho - HUdE, 2006.

\begin{tabular}{|l|l|}
\hline \multicolumn{1}{|c|}{ Meios e instrumentos de trabalho } & Objeto de trabalho \\
\hline $\begin{array}{l}\text { Materiais, medicamentos e equipamentos para prestação da assistência de enfermagem e } \\
\text { demais atividades; }\end{array}$ & Paciente \\
Aparelhos para realização de exames; & \\
Aparelhos para monitoramento da saúde (oxímetro, respiradores, gasômetros etc) & Familiares \\
Conhecimento técnico. & \\
Campanhas e feiras de saúde; & \\
Conhecimento técnico & \\
Aulas, palestras, cursos, campanhas, treinamentos, feiras de saúde; & \\
Tomada de decisões quanto às atividades a serem realizadas; & \\
Gerenciamento dos colaboradores de enfermagem; & Trabalhadores de enfermagem \\
Material didático (apostilas, blocos, data show, transparências); & \\
Material de apoio à assistência e gerenciamento de enfermagem; & \\
Aparato tecnológico (celular, aparelho de som, computador); &
\end{tabular}


Marx (1982: 203) considera que "o meio de trabalho é uma coisa ou um complexo de coisas que o trabalhador insere entre si mesmo e o objeto de trabalho e lhe serve para dirigir sua atividade sobre esse objeto". Partindo desta consideração, todos os instrumentos necessários para a efetivação da assistência de enfermagem ao paciente ou familiar, assim como para a coordenação dos trabalhadores de enfermagem, constituem-se como "um complexo de coisas" que viabilizam a realização da atividade. $\bigcirc$ autor ainda acrescenta que “... os meios de trabalho servem para medir o desenvolvimento da força humana de trabalho e, além disso, indicam as condições sociais em que se realiza o trabalho".

As falas permitiram a apreensão de meios e instrumentos de trabalho semelhantes dentro de cada modelo; ou seja, quando as falas remetem ao modelo assistencial, os instrumentos de trabalho aplicados para a atuação junto ao objeto de trabalho são iguais; quando a referência é para o modelo gerencial, novamente os meios e instrumentos se assemelham. Ressalta-se que, mesmo as similaridades guardam especificidades de acordo com o setor de atuação, como o aparato tecnológico do Centro de Terapia Intensiva, ou as incubadoras da UTI Neonatológica ou outros.

Os meios e instrumentos de trabalho também podem ser apreendidos na abordagem do modelo gerencial, na qual, a própria atividade gerencial constitui uma atividade meio. Acerca disso, Mishima et al (1997), contextualizando a gerência como instrumento de trabalho, colocam que ao se pensar mais concretamente na gerência em saúde, pode-se dizer que ela é uma atividade de meio, cuja ação central está posta na articulação e 
integração do trabalho. Ou seja, à medida que a gerência é um instrumento que consolida políticas entre instituição (na pessoa do gerente) e demais trabalhadores, ela deixa de ser uma atividade e passa a ser um instrumento de trabalho, essencial para a efetivação de políticas e articulação de serviços.

A descrição das atividades executadas e dos materiais e equipamentos destinados ao desenvolvimento das mesmas permitem evidenciar o expressivo recorte ente as atividades assistenciais e gerenciais, desempenhadas pelos trabalhadores de enfermagem. Esta característica presente na enfermagem, desde a distinção ente nurses e lady nurses, realizada pela pioneira Florence Nightgale, sendo as primeiras destinadas a prestação dos cuidados e as segundas às atividades de supervisão e ensino (Felli, 2002) - também pôde ser verificada quando da recomposição do processo de trabalho.

Peduzzi e Anselmi (2002), em estudo desenvolvido para caracterizar o processo de trabalho do enfermeiro e do auxiliar de enfermagem, encontraram uma rígida divisão de trabalho entre essas duas categorias, devido à cisão entre os momentos de concepção e execução do trabalho. Isto porque quem executa o cuidado de enfermagem não participa diretamente de seu planejamento, embora forneça informações que alimentam esta ação. Da mesma forma, as falas acima relacionadas evidenciam que efetivamente há dois lados da mesma enfermagem: a que se volta para o paciente e familiares (atividades assistenciais ou execução 
do trabalho) e o outro lado, voltado aos trabalhadores da equipe de enfermagem (atividades gerenciais ou planejamento do trabalho).

\subsubsection{Formas de organização do trabalho}

As formas de organização do trabalho são captadas no HUdE pela divisão de responsabilidades e realização das atividades em três diretorias, conforme referido na descrição do campo de estudo, sendo a Divisão de Enfermagem subordinada à Diretoria Adjunta de Serviços Assistenciais. Todas as unidades assistenciais são subordinadas à Divisão de Enfermagem, que tem por responsabilidades planejar, coordenar, executar e avaliar as atividades administrativas e assistenciais desenvolvidas pelos profissionais de enfermagem nas diversas áreas da instituição. O Serviço de Segurança e Medicina do Trabalho - no qual vincula-se a Enfermagem do Trabalho, subordina-se ao Serviço de Assistência Médica da Universidade.

Cada unidade assistencial possui um enfermeiro chefe, cuja responsabilidade está na coordenação da equipe de enfermagem em seu âmbito de atuação e na articulação com a Divisão de Enfermagem. Este enfermeiro também define a organização deste trabalho, juntamente com a escala de profissionais.

A assistência de enfermagem está presente ininterruptamente e as jornadas de trabalho diferem de acordo com o vínculo contratual, sendo: a) 30 horas semanais para os servidores, regidos pelo 
Regime Jurídico dos Servidores Públicos da União (Lei №. 8.112, de 11 de dezembro de 1990); b) 30 horas semanais para os funcionários contratados diretamente pelo hospital; c) 24 horas semanais para os funcionários da Secretaria da Saúde, cedidos ao HUdE; d) 40 horas semanais para os trabalhadores vinculados à universidade; e) turnos noturnos para os trabalhadores enquadrados nos itens $a$ e $b$.

Os enfermeiros e auxiliares de enfermagem são os responsáveis pela prestação da assistência propriamente dita, junto aos pacientes e familiares; os enfermeiros chefes de unidades, além de desempenhar a função assistencial junto aos pacientes e familiares, também estão incumbidos de gerenciar a equipe de enfermagem sob sua supervisão e garantir os meios e instrumentais necessários para a garantia da prestação dos cuidados. Os enfermeiros da Divisão de Enfermagem, por sua vez, responsabilizam-se pelos serviços de enfermagem de todo o hospital, tanto no âmbito assistencial, administrativo, gerencial ou educacional. A enfermagem na Educação Continuada responde pelos treinamentos e atualizações de todos os trabalhadores de enfermagem do hospital. A enfermagem do trabalho tem por função a realização dos exames periódicos de saúde, a notificação dos acidentes de trabalho e o atendimento junto aos trabalhadores que procurarem o serviço, assim como o desenvolvimento de trabalhos educacionais, de prevenção de acidentes e promoção do uso dos EPIs. Também estão presentes, na Instituição os docentes de enfermagem, juntamente com os alunos e estagiários da área, que estão vinculados à universidade. 
No momento da realização das reuniões do grupo focal, o tema processo de trabalho foi colocado em discussão, uma vez que os dados captados até àquele momento estavam relacionados a informações administrativas e gerenciais e, portanto, emergia a necessidade de se conhecer a percepção dos próprios atores sociais que compõem e se submetem a estes processos. Nesta perspectiva, as falas permitiram a composição de um cenário paradoxalmente constituído por processos destrutivos e favoráveis à saúde, da mesma forma como colocados por Breilh e Granda (1989) em suas considerações.

Quadro III: Apreensão dos processos favoráveis e destrutivos à saúde, presentes na organização do trabalho - HudE, 2006.

\section{Organização do trabalho}

Processos favoráveis à saúde

Processos destrutivos à saúde

“... o HUE tem um bom relacionamento e o pessoal de fora, os pacientes elogiam muito os cuidados daqui de dentro, a gente recebe muito elogio..." (John S. Bach)
“... nós percebemos assim que as clínicas que dão mais trabalho, mas transtornos para o hospital na divisão de enfermagem é aquele grupo onde não tem a interação enfermeiro-médico (...) é problema mesmo da divisão de trabalho que compromete a organização em função dos profissionais que estão ali..." (John S. Bach)

“... nós temos dificuldade de nos integrar com as próprias colegas da unidade. A maternidade é a maternidade e o berçário é o berçário! Ninguém quer interagir!" (Rossini)
“... é muito bom o nosso relacionamento conversando médico, enfermagem, éé os auxiliares, temos os residentes, é muito bom, a divisão nossa de trabalho, às vezes, não é só pela nossa chefia, às vezes nós mesmos a gente ali entra num consenso de onde a gente vai ficar, de como a gente vai trabalhar..." (Rossini)
"Algumas pessoas se espantam com o clima da nossa UTI, elas se espantam com esse relacionamento entre médicos, técnicos e auxiliares e os enfermeiros, cada um tem seu papel muito bem definido... (...) Os médicos ouve os enfermeiros que ouve os auxiliares que tem até a de chegar e falar: ô doutor eu não tô concordando com o que o senhor tá falando não..." (Giacomo Puccini) "...claro que tem sempre alguns (refere-se aos médicos) que não ouvem não, eu sou o médico pronto e acabou!" (Giacomo Puccini) 
As falas expostas pelos participantes durante a contextualização do processo de trabalho estão fortemente calcadas no relacionamento interpessoal desenvolvido com os trabalhadores de enfermagem e demais trabalhadores da área da saúde. Como demonstram os recortes originais acima relacionados, subdivididos de acordo com o caráter destrutivo ou potencializador atribuído, podemos apreender o tênue limiar onde ora acontece, ora não, a promoção da qualidade de vida no trabalho.

Os fragmentos acima retratam a contradição vivida no ambiente de trabalho, captados pelas falas. Num mesmo dia, numa mesma abordagem, os mesmos sujeitos apresentam discursos que, num primeiro momento poderiam parecer desconexos - uma vez que, concomitantemente, aparecem críticas e elogios para uma mesma realidade - carregam a exata vivência profissional: mesmo o trabalho às vezes apresentando-se como causador de insatisfação, ele também recompõe um cenário de relacionamentos que proporcionam prazer e satisfação.

Segundo Peduzzi (2001), as articulações ente os agentes de trabalho ocorrem pela comunicação - denominador-comum do trabalho em equipe, que decorre da relação recíproca entre trabalho e interação. Pode-se perceber, de forma bastante clara, os reflexos da divisão social do trabalho nas percepções levantadas. Levando-se em conta apenas a divisão social do trabalho, apreende-se que o denominador-comum não é tão comum entre os trabalhadores, pois o trabalho é comprometido devido à falta de comunicação da equipe. 
Em contrapartida, o exercício do ouvir ao outro - sentido da comunicação - já carreia em si a conotação positiva do relacionamento estabelecido com a equipe. A satisfação obtida com as relações saudáveis no ambiente de trabalho perpassam os muros institucionais e passa a ser reconhecida pelos próprios pacientes atendidos no hospital, como fica evidenciado em uma das falas.

As falas ainda permitem analisar a hegemonia médica, construída ao longo dos anos de modelo clínico biologicista, no qual a cura constitui-se na solução para a doença, desencadeada por mecanismos puramente biológicos ao nível individual. O médico é o detentor dos meios e instrumentos de trabalho que viabiliza a restauração da saúde ao corpo do objeto de trabalho. Para Almeida e Rocha (1997), no modelo clínico é o médico o agente que, histórica e socialmente, tem por finalidade a recuperação do corpo individual, sendo que os demais trabalhadores vão se agregando a este trabalho, constituindo, assim, o trabalho coletivo.

As autoras ainda referem Castellanos et al (1989), que considera que o trabalho de enfermagem no modelo de saúde individual (modelo clínico), passa a ser um instrumento ou um meio do processo de trabalho médico. Apesar desta consideração permitir uma interpretação de submissão do trabalho de enfermagem ao trabalho médico, ela também permite a compreensão da enfermagem como meio para efetivação de uma ação junto ao objeto de trabalho. Assim, da mesma forma que, que o gerente de enfermagem dispõem de trabalhadores assistenciais para a concretização do cuidado, o mesmo ocorre com o profissional médico. 
Esta articulação cotidiana e indispensável para a integralidade da assistência junto aos pacientes e familiares permite transparecer a relevância dada a este profissional e à sua postura frente à equipe, fato que, inexoravelmente, constitui num determinante das relações de trabalho que pode motivar ou desestimular a execução do trabalho.

As percepções dos participantes permitem a apreensão do processo de trabalho como meio onde as relações são desenvolvidas, sendo que, num mesmo contexto, estas relações podem proporcionar momentos de bem-estar, satisfação e reconhecimento, como também sentimentos de ignorância, alienação e inferioridade. Esta teia retrata com fidedignidade o perfil do relacionamento desenvolvido no ambiente de trabalho, composto por paradoxos que estão presentes na constituição do perfil saúde-doença dos trabalhadores, bem como possibilitam ou dificultam a promoção da qualidade de vida no trabalho.

Observa-se que, não aleatoriamente, os recortes selecionados para a caracterização dos processos favoráveis e destrutivos da saúde originam-se dos mesmos sujeitos. Este retrato evidencia a própria vulnerabilidade do trabalhador frente à contextualização do ambiente de trabalho, sendo que sua sensibilidade responde a medida em que determinado aspecto das relações de trabalho é enfatizado. Ou seja, quando a abordagem estava direcionada aos aspectos destrutivos do processo de trabalho, as falas retratavam os aspectos negativos vivenciados no ambiente de trabalho; em contrapartida, quando a tônica centrava nos aspectos potencializadores, de imediatos as falas passavam aos momentos que proporcionaram prazer, 
reconhecimento e valorização no relacionamento interpessoal. Assim, as relações de trabalho não são, predominantemente, negativas ou positivas, mas alternam de acordo com os profissionais da equipe e o contexto apresentado.

Semelhantemente ao evidenciado nas falas, Elias e Navarro (2006) encontraram, em sua pesquisa com trabalhadores de enfermagem, que as relações entre as colegas de trabalho também foram evidenciadas de formas ambíguas, ora como muito boas, com um discurso de trabalho em equipe, ora com relatos de disputas internas.

A enfermagem, enquanto equipe, também desenvolve suas atividades com outros profissionais da área da saúde. A assistência à saúde contempla um leque de atuações de diversos profissionais que direcionam suas ações a um mesmo objeto de trabalho - o que implica, necessariamente, que, em algum momento, estes profissionais trabalhem em equipe, partilhando o mesmo objeto. O quadro a seguir permite visualizar as falas que expressam essa transformação que incide sobre o mesmo objeto de trabalho. 
Quadro IV: Apreensão dos processos favoráveis e destrutivos à saúde, presentes na organização do trabalho - HudE, 2006.

\section{Organização do trabalho}

“... eu sempre falo pra elas: 'gente, nós somos uma equipe (...) eu acho assim, a gente como chefe da equipe né, a gente tem que sentar e conversar, porque é uma equipe, os nossos olhos são eles né, entendeu?" (Mahler)
“... na Clínica Médica e eu já percebi que a rotatividade é muito grande, então assim atrapalha demais porque assim ééé a gente, eu como enfermeira, eu tenho que ter uma postura assim, eu tenho que ter autoridade, mas sem agressividade, porque muitos usam e abusam, então a gente tem que intervir..." (Mahler)
“... a gente vai ter um trabalho positivo, sempre a gente vai fazer sempre uma coisa boa, porque eu acho que é isso aí, é trabalhar em equipe, trabalhar bem!" (Chopin)
“... a gente tem que se colocar no lugar do auxiliar também, porque tem dia que tem um auxiliar só pra 18 pacientes, então você tem que dar uma de auxiliar, voce tem que ir lá ajudar, dar banho... uma equipe tem que funcionar junto!" Mahler)

“...quando alguém tem um problema em casa quer vir fazer plantão, porque aqui distrai! $O$ ambiente é muito bom, muito bom de trabalhar é uma terapia pra gente..." “... nunca vi tanta submissão da enfermagem como nós daqui..." (Erik Satie)

(Joseph Haydn)

...daí todo mundo corre, com a o mesmo objetivo, é isso que é importante..." (Orlando Gibbons)
“... eu queria muito que acima de mim fosse alguém de outra categoria, nutrição, fisioterapia, enfermagem, qualquer outra, menos médico, porque qualquer outro profissional entenderia o hospital melhor!" (John S. Bach)

As falas permitem a apreensão do valor atribuído ao trabalho em equipe. Diferentemente das relações de trabalho - que não necessariamente implicam na existência de um trabalho em equipe - a percepção dos sujeitos denota a importância da realização do trabalho em equipe. Cabe ressaltar que o trabalho na área da saúde na atualidade, necessariamente, possui um caráter multiprofissional, com finalidade e objeto comum: a recuperação da saúde do paciente. Contudo, cada um dispõe de seus conhecimentos 
técnicos e específicos para colaborar com essa finalidade o que nem sempre ocorre em uníssono.

Por isso, a relevância dada ao trabalho em equipe está na harmonia do trabalho em grupo, que deixa de ser apenas a superposição de ações voltadas a um objetivo comum. Passa a representar a articulação destas pessoas, respeitando suas especificidades, de forma que as ações deixem de ser fragmentadas e passem constituir uma só: a assistência em suas multifacetadas possibilidades.

Cabe uma ressalva, em relação à fala de Mahler, que cita a rotatividade como a grande movimentação de pessoas (médicos, residentes, alunos, estagiários e outros profissionais) na unidade, que acaba comprometendo a continuidade do trabalho, pelo tumulto causado. Não há relação, neste contexto, da expressão rotatividade referindo-se ao processo de trocas constantes de funcionários devido ao desgaste dos mesmos.

Peduzzi (2001) faz uma distinção na tipologia do trabalho em equipe: a equipe como um agrupamento de agentes e a equipe como integração de trabalho. A primeira, denominada de equipe agrupamento, ocorre a justaposição das ações e o agrupamento dos agentes; na segunda, equipe integração, ocorre a articulação das ações e a interação dos agentes.

Partindo desta premissa, tem-se, no ambiente de trabalho descrito pelos participantes, ambas tipologias: a equipe agrupamento, que desencadeia os processos destrutivos à saúde, uma vez que se configura como a falta de articulação, a submissão de alguns trabalhadores, a rotatividade comprometendo $\mathrm{o}$ andamento do trabalho; e a equipe 
integralidade, identificada como processos que favorecem a saúde, pela harmonia da equipe refletida na sensação de prazer de estar no ambiente de trabalho.

Fica evidente em uma das falas, que quando o ambiente de trabalho apresenta-se prazeroso, ele passa a substituir o espaço familiar. Ou seja, frente às intempéries do contexto familiar, o trabalho passa a ocupar o lugar prioritário para o descanso (ainda que em atividade) do profissional. Mas há também a interpretação de que o trabalho passa a ser uma fuga dos problemas da vida particular, o que permite a compreensão de que, se as coisas não estão bem no lar, é melhor ficar no ambiente de trabalho - na busca do descanso do sofrimento mental proporcionado por um ambiente mais agradável. Este tem sido evidenciado como um aspecto extremamente favorável do trabalho.

Em contrapartida, quando o trabalho deixa de ser realizado em equipe, evidenciam-se os processos destrutivos da saúde, evidenciados, por exemplo, na fala de John S. Bach que volta a ressaltar a hegemonia médica, especialmente quando este profissional ocupa uma posição de poder. Há, nitidamente, a cisão do significado do trabalho de equipe e passa a vigorar a justaposição de ações - que neste caso, necessariamente são ações de subordinação e alienação em relação ao profissional de enfermagem. Peduzzi (2001) reitera que as diversidades técnicas entre os profissionais se legitimam nas desigualdades sociais consolidadas entre os mesmos. Isso significa que há profissões que são "superiores" a outras, e que há relações hierárquicas de subordinação entre os profissionais. 
Isso desencadeia o enfraquecimento da articulação do trabalho em equipe, uma vez que a supremacia de um implica, necessariamente, na subordinação de outro. Esta desigualdade invalida a composição de um trabalho integrado, uma vez que a falha da comunicação interrompe a confluência de ações, dando margem à mera sobreposição das mesmas.

Outra fala que merece referência refere-se à uma outra abordagem de Mahler (enfermeiro responsável por uma unidade de trabalho) quanto aos profissionais nível técnico, em relação às sobrecargas que este trabalhador de enfermagem está exposto quando se responsabiliza por um número superior de pacientes.

No trabalho realizado Silva (1996), para a compreensão do processo saúde-doença vivenciado pelos trabalhadores de enfermagem no desempenho de seu trabalho, foi evidenciado que no processo de trabalho a extração de mais-valia ocorre pela intensificação do ritmo de trabalho e aumento da produtividade. Essa característica institucional, evidenciada pela fala dos participantes, faz com que os trabalhadores, devido ao reduzido número de profissionais e aumento constante da demanda, trabalhem em condições inadequadas, com a intensificação do ritmo de suas atividades para dar conta do trabalho.

Entretanto, o foco para esta percepção colocada pelo sujeito, vai além da compreensão de sobrecarga de trabalho; ela mostra o reconhecimento e preocupação do enfermeiro, enquanto gerente da equipe de enfermagem, para esta sobrecarga de trabalho a que seu trabalhador está exposto. Assim, diante desta circunstância, o enfermeiro insere-se no trabalho em equipe e 
passa a desempenhar funções essencialmente assistenciais, de forma a viabilizar a continuidade do cuidado e minimizar a sobrecarga do outro profissional. Chama atenção que, em alguns momentos, o trabalho em equipe supera a cisão existente entre o planejamento e a execução do cuidado, e a enfermagem passa a desempenhar suas atividades efetivamente como equipe, vislumbrando o mesmo produto final do trabalho - a transformação dos processos saúde-doença dos pacientes.

Padilha e Souza (1999), em estudo sobre as reflexões de enfermeiras acerca da qualidade de vida, encontraram a valorização da equipe como sendo muito importante para a melhoria da qualidade de vida; ou seja, quando as relações de trabalho ocorrem de forma a valorizar cada membro da equipe, conseqüentemente ocorre a valorização individual e coletiva da qualidade de vida no trabalho.

Um dos problemas que mais se destaca na referência ao processo de trabalho é o relacionamento entre trabalhadores e instituição. As relações de trabalho e o trabalho em equipe envolvem os trabalhadores da área da saúde, em seus diversos campos de atuação; as relações organizacionais, por sua vez, referem-se ao estilo de relacionamento que é estabelecido entre os trabalhadores e a instituição para o qual trabalham.

A percepção dos trabalhadores, captada por meio das filmagens dos encontros do grupo focal, demonstra como as ações da Instituição interferem, de forma favorável ou comprometedora, na saúde dos trabalhadores. Reforça-se o entendimento que, neste caso, a análise referese especificamente ao HUdE e à universidade a qual este se subordina, uma 
vez que são estas duas organizações se responsabilizam pelos trabalhadores do hospital. Assim, abaixo são relacionados alguns recortes das falas que demonstram os aspectos favoráveis e destrutivos originados pela relação dos trabalhadores com a Instituição:

Quadro V: Apreensão dos processos favoráveis e destrutivos à saúde, presentes na organização do trabalho - HudE, 2006

\section{Organização do trabalho}

\begin{tabular}{|c|c|}
\hline Processos favoráveis à saúde & Processos destrutivos à saúde \\
\hline $\begin{array}{l}\text { "... eu não tive liberação par ao mestrado,, } \\
\text { mas tive uma flexibilização muito grande..." } \\
\text { (Erik Satie) }\end{array}$ & $\begin{array}{l}\text { “... tudo aqui é voltado pra Faculdade de Medicina, } \\
\text { enfermagem aqui dentro não tem prioridade em } \\
\text { nada (...) é ignorância total da instituição em relação } \\
\text { à nós...." (Erik Satie) }\end{array}$ \\
\hline $\begin{array}{l}\text { "... o hospital investiu mais em tecnologia, } \\
\text { isso tem e acaba ajudando o funcionário." } \\
\text { (John S. Bach) }\end{array}$ & $\begin{array}{l}\text { “... muitas coisas a gente vai pedir e a instituição diz } \\
\text { não!” (John S. Bach) }\end{array}$ \\
\hline \multirow[t]{2}{*}{$\begin{array}{l}\text { “... a instituição fornece alguns cursos pela } \\
\text { universidade..." (Joseph Haydn) }\end{array}$} & $\begin{array}{l}\text { “... o funcionário não tem direito de almoçar se não } \\
\text { estiver trabalhando o dia inteiro e o estudante pode } \\
\text { comer e ir embora." (Amadeus Mozart) }\end{array}$ \\
\hline & $\begin{array}{l}\text { “.. o hospital não dá folga, a gente que tem que } \\
\text { trocar plantão, a gente deixou de fazer muitos } \\
\text { cursos por estar trabalhando..." (Rossini) }\end{array}$ \\
\hline
\end{tabular}

As falas evidenciam o favorecimento, por parte da Instituição, ao curso de medicina, reproduzindo o padrão de hegemonia médica perpetuada nas relações ao longo dos anos. Este privilégio reflete, imediatamente, nas demais profissões - e em especial a de enfermagem, que sofre a subordinação, ficando em plano secundário em suas solicitações e, inclusive, em relação aos benefícios disponibilizados pelo Hospital, como as 
refeições, que são reguladas aos funcionários e disponibilizadas, sem critérios aos alunos de medicina.

Novamente, pode-se identificar um mesmo sujeito, Erik Satie, referindo aspectos favoráveis e destrutivos no relacionamento com a Instituição: ao mesmo tempo em que a mesma privilegia o profissional médico, ela também abre possibilidade de flexibilização no horário de trabalho do profissional de enfermagem para a realização do mestrado. $\mathrm{O}$ mesmo não ocorre com um outro trabalhador, que refere a perda de alguns cursos por não ter sido liberado pela Instituição para fazê-los.

Esta coexistência entre os aspectos positivos e negativos presentes no processo de trabalho em seus diversos ângulos de análise reitera o sistema de contradições que determina a saúde do trabalhador, proposto Breilh (1995), no qual o processo de trabalho não é em si mesmo puramente benéfico para a saúde, nem exclusivamente danoso; seus aspectos benéficos e suas facetas destrutivas coexistem e operam de modo distinto, de acordo com o momento histórico e a classe social a que se referem.

Desta forma, as relações estabelecidas no processo de trabalho reproduzem o sistema contraditório que determina o perfil saúdedoença dos trabalhadores de enfermagem, uma vez que dentre os componentes que compõe o processo de trabalho, o trabalho propriamente dito (Marx, 1982), foi a ênfase dada aos participantes do grupo de trabalho. Isto porque é mediado pelas relações que as atividades são desenvolvidas, os meios e instrumentos de trabalhos são utilizados, o trabalho é organizado 
e a finalidade do trabalho, previamente pensado (definido por Marx como intencionalidade) é alcançada junto ao objeto de trabalho.

Segundo Mandu e Almeida (1999: 55), "é no processo produtivo, nas relações, que o homem realiza sua própria essência". Depreende-se, portanto, que as relações estabelecidas no ambiente de trabalho são um importante aspecto a ser investigado quanto à sua capacidade na promoção da qualidade de vida no trabalho. Conforme pode ser compreendido nos recortes das falas dos sujeitos, o entremeio que reside entre os aspectos positivos e negativos das relações de trabalho é o local exato onde se desenvolve a promoção da saúde ou da doença.

\subsection{Qualidade de vida no trabalho - QVT}

A abordagem inicial sobre o tema ocorreu buscando-se compreender o que os sujeitos apreendem a qualidade de vida no trabalho, decorrente do processo de trabalho no qual se inserem.

Seqüencialmente houve a contextualização de como se desenvolve a qualidade de vida no ambiente de trabalho, ou seja, quais são as motivações dos trabalhadores de enfermagem para que, apesar das controvérsias, eles compareçam ao ambiente de trabalho. E, por último, quais ações promovem a qualidade de vida ou como ocorre o comprometido, frente às dificuldades enfrentadas no cotidiano. 


\subsubsection{Significado}

\section{As falas abaixo demonstram a percepção de alguns}

participantes, em relação à sua qualidade de vida no trabalho:

"... ter saúde, se sentir com saúde, se sentir bem, fazer o que gosta, isso pra mim é qualidade de vida ideal, estar satisfeito, não importa o dinheiro (..) ter boas condições de trabalho, né, ser valorizado, ver que você é útil no seu serviço, na sua atividade, isso é qualidade, é se sentir útil." (John S. Bach)

"... ter saúde física, mental, ter um bom emprego (...) quando você tem boa integração com a equipe você tem qualidade de vida, quando você é reconhecido pelo o que você faz, quando você vê a recuperação de alguém que está doente e você se sente muito bem!

" (Joseph Haydn)

"...justiça social, respeito ao ser humano..." (Erik Satie)

"... saúde, segurança, dinheiro, lazer, educação..." (Edward Elgar)

"... pra mim qualidade de vida funciona assim, iguala a balança comercial, um ano é favorável o outro ano é desfavorável. Acho que no ambiente vai ocorrer, não vou dizer equilíbrio, mas talvez o aumento dos fatores positivos em detrimento dos fatores negativos, daí você vai ter que administrar com aquilo que está acontecendo, não só ter críticas da parte ruim, mas saber tirar das partes ruins um aprendizado pras partes que vão ser boas, nada se perde, tudo se transforma, eu vejo não só no ambiente de trabalho, mas em toda a estrutura. Acho que no momento que aquelas coisas boas estiverem sobressaindo, você tem qualidade de vida, a partir da hora que o patamar está igual ou negativo, daí nós vamos ter o que podemos dizer de perda da qualidade." (Prokofiev)

"...qualidade no trabalho é fazer parte da equipe, do trabalho, ver que seu trabalho contribui pra alguma coisa, pro seu crescimento, pro crescimento das pessoas, ter respaldo naquilo que você ta fazendo... (Leonard Bernstein)

"... acho que é você estar bem, se sentir útil..." (Rossini)

As falas permitem a apreensão do significado de QVT, inicialmente, como sendo a satisfação das necessidades básicas, como se sentir com 
saúde, ter emprego, segurança, lazer, dinheiro, educação, justiça social e respeito.

Assim, em primeira instância, a análise da qualidade de vida não dissocia a vida particular da vida laboral; a satisfação das necessidades humanas, citadas acima, supera qualquer outro fator associado ao assunto. Ou seja, é inegável que, para se ter qualidade de vida, primeiramente necessita-se das condições mínimas de desenvolvimento enquanto ser humano. A satisfação destas necessidades básicas permite a compreensão do porque, mesmo em situações adversas, o profissional mantém-se no ambiente de trabalho.

Partindo da premissa que a saúde, a educação, o lazer e o dinheiro são condições básicas mínimas para que se tenha qualidade de vida (boa ou má) e que é através do trabalho que o acesso a tais elementos torna-se viável, a condição sine quanon é estar trabalhado, independente das condições. Isto porque, estando no trabalho, a percepção de qualidade de vida amplia-se, porque as necessidades básicas já estão supridas e, portanto, abre-se espaço a outras necessidades. Contudo, se, na ausência de alguma atividade que ofereça fonte de renda, as necessidades primárias não são satisfeitas, a prioridade passa a ser a busca por esta condição que as satisfaça.

Assim, a partir desta análise, consegue-se captar a importância do trabalho na sociedade, já que, por meio dele, ocorre a inserção social e a possibilidade de satisfação das necessidades humanas básicas, garantindo uma certa qualidade de vida. Esta conceituação evidencia a submissão do 
ser humano ao trabalho, o que justifica a subordinação a uma série de fatores que comprometem sua saúde, mas que, em contrapartida, compensam o acesso à sua sobrevivência.

Satisfeitas as necessidades primárias, surge a percepção de qualidade de vida no trabalho como sendo "fazer o que se gosta", independente de qualquer outra razão. Realmente, quando as necessidades primordiais estão satisfeitas, a importância aos fatores muda de foco e trabalho passa a compor a principal variável associada à QV .

Desta forma, as condições de trabalho, as relações estabelecidas neste ambiente e o reconhecimento profissional passam a ocupar lugar de importância na promoção da QVT. Observa-se que os participantes referem os elementos de uma forma genérica, subentendendo-se que são as boas condições e relações de trabalho e o reconhecimento profissional de forma positiva desencadeiam a satisfação que, por sua vez, corrobora com a QVT. Isto é evidenciado na fala de Prokofiev, fundamentada nos fatores positivos e negativos do trabalho, sendo que a prevalência de um extremo ou de outro pode favorecer ou comprometer a QVT.

A busca do significado para QVT coincide com a consideração de Felli e Tronchin (2005) na qual para compreender o significado da qualidade de vida e suas implicações na saúde dos trabalhadores de enfermagem, torna-se necessário apreender este significado para cada trabalhador.

Em estudo sobre a reflexão e percepção de enfermeiras sobre a QV, Padilha e Souza (1999); Leitão (2002) encontraram que o trabalho é 
percebido como algo significativo e imprescindível na concepção da qualidade de vida, em especial por possibilitar às enfermeiras sentirem-se importantes, produtivas e que, em contraposição dos fatores destrutivos à saúde, as enfermeiras expressaram satisfação e orgulho pelo seu trabalho.

A satisfação das necessidades básicas, expressadas pelos participantes, convergem com o exposto por Felli e Tronchin (2005) no qual a expressão "qualidade de vida" perpassa pela qualidade da saúde, suas possibilidades e limitações, tanto individual como coletiva e, ainda, no sentido de satisfazer as necessidades como as de moradia, educação, alimentação, trabalho, lazer, relações sociais, enfim, dimensões que favorecem a conquista da cidadania.

Os significados de "qualidade de vida" (QV) também se associam tanto ao momento da vida dos indivíduos em sociedade, como ao momento de trabalho - qualidade de vida no trabalho (QVT), entendendo que estes se constroem mutuamente. Esta afirmação esta pautada no entendimento de que não há como dissociar a vida e o trabalho, bem como não reconhecer a interface do trabalho na nossa QV (Felli, Tronchin, 2005). Devido ao trabalho ser uma característica inerente ao ser humano e meio de acesso ao consumo de bens e serviços, que garantem a manutenção da sobrevivência, a QV, também, é garantida nas esferas da vida particular e produtiva, sendo que o desequilíbrio de uma esfera inexoravelmente compromete o desenvolvimento da outra.

Tomando-se a definição da Organização Mundial da Saúde, entendese por QV a percepção do indivíduo de sua posição na vida, no contexto da 
cultura e sistema de valores nos quais vive e em relação aos seus objetivos, expectativas, padrões e preocupações (WHOQOL, 1998). Ou seja, apesar da individualidade na percepção de cada indivíduo em relação à sua QV, há um consenso acerca das condições mínimas necessárias para o favorecimento da QV voltada ao trabalho, como colocadas pelos participantes.

No referencial da Determinação Social, Breilh et al (1990) concebem a QV como resultado histórico e social, no qual os membros de cada classe social inserem-se na esfera produtiva com seus padrões característicos de consumo e formas específicas de organização e cultura. Estas se desenvolvem em um sistema de contradições, em que se opõem, por um lado, os bens ou forças benéficas que protegem sua saúde e, por outro, os aspectos destrutivos que os deterioram. Este sistema de contradições, em última instância, modela a qualidade de vida e os padrões de saúdeenfermidade resultantes, chamado perfil epidemiológico. Assim, as percepções dos sujeitos do estudo enfatizam a QV como resultante dos processos favoráveis, mesmo reconhecendo que é a interação dos fatores destrutivos que também a determina.

\subsubsection{Motivação para o trabalho}

As motivações dos trabalhadores de enfermagem para execução das atividades relacionadas ao seu trabalho foram expressas nas falas: 
satisfeito, quando o meu grupo ta atendendo bem..." (John S. Bach)

“... pela recompensa do paciente, pela formação de uma identidade social e pessoal, o que me motiva hoje é o que o paciente espera de nós..." (Erik Satie)

"...o que me motiva a vir: primeiro é fazer o que eu faço, porque eu sou apaixonada, fazer com quem eu faço, porque eu adoro lidar com crianças, tenho paixão por elas (...) então é muito gostoso trabalhar lá e a minha equipe também, porque não tem um dia que eu não dou boas risadas com eles, porque gente tem uma interação muito gostosa também, a equipe de enfermagem, os pacientes." (Amadeus Mozart)

“... a gente não vem aqui pelo dinheiro, vem aqui porque a gente gosta mesmo (...) o que me motiva a vir é meus pequenininhos, a minha equipe é maravilhosa, minha chefe é um espetáculo de pessoa, os médicos também são muito bons, nós aprendemos muito naquele lugar e a cada dia que eu falo que eu vou trabalhar, eu saio satisfeita, eu venho satisfeita, o berçário é um lugar maravilhoso!" (Rossini)

"... eu também sou apaixonada pelo o que eu faço, sou apaixonada apela enfermagem, se pudesse faria tudo de novo (...) acho que é muito bom a enfermagem é muito gratificante, só de você ver a recuperação do paciente mesmo, isso já é uma coisa muito maravilhosa, saber que você vai cuidar de uma pessoa e ela vai sair muito boa, infelizmente quando ela não sai a gente fica muito triste, mas ..." (Joseph Haydn)

“... quando eu estava prestes a me separar, se não fosse pelos meus filhos, eu preferia ficar trabalhando do que voltar pra minha casa, porque ali eu estava sorrindo..." (Joseph Haydn)

"...eu ainda me sinto motivado porque em várias vezes eu cheguei aqui com problemas de casa, mas daí você olha e seus pacientes estão ali, é a hora deles, você abre mão do seu problema e começa a cuidar dos pacientes, em diversas situações não só a equipe me ajudou, mas só o cuidar dos pacientes eu já saia daqui com outro astral, no cafezinho eu já tava contente, rindo..." (Giacomo Puccini)

"... na licença que eu falei, eu tirei, mas eu não conseguia fica em casa, por mais que eu preenchesse o tempo, o melhor lugar era estar aqui dentro. De todos os lugares dentro do quadro que eu estava, o lugar que eu me sentia melhor era aqui dentro do hospital." (Erik Satie)

“... minha situação é diferente da de vocês porque enquanto vocês trabalham com pacientes, eu trabalho com vocês, mas o que me motiva a vir é o respeito que eu tenho e o reconhecimento profissional, os elogios, as vezes deixam até o plano de saúde pra vir tratar conosco, temos pouco reconhecimento, mas temos..." (Edward Elgar) 
A busca pelas motivações que levam aos trabalhadores a comparecerem ao trabalho objetiva apreender o por quê, mesmo estando submetido a condições insalubres e às sobrecargas de trabalho, o trabalhador continua comparecendo diariamente ao trabalho. Óbvio, como já citado anteriormente, a necessidade da inserção social e da satisfação das necessidades é, indubitavelmente, um dos grandes motivadores. Contudo, interessa conhecer o 'algo mais', já que a remuneração financeira não sustentaria por muito tempo a permanência no local de trabalho. Com essa premissa, as falas demonstram o 'algo mais', captado na subjetividade não perceptível do trabalho.

Uma das motivações, comum à maioria dos sujeitos, foi "gostar do que faz". A escolha da profissão por paixão ressuscita o "cuidar pela arte, pelo sacerdócio, pelo amor", conceito arraigado aos primórdios da enfermagem e que, ainda hoje, permanecem. $\mathrm{O}$ ato de cuidar das pessoas, como conseqüência de uma paixão deliberadamente gratuita, aparece como um importante fator que motiva os trabalhadores a permanecerem no trabalho. Estes sentimentos explicitam a devoção destes profissionais que secundarizam a remuneração pelo prazer de exercer a profissão.

Outro fator que mobiliza os trabalhadores é o sentimento de prazer desencadeado pela resposta positiva do paciente aos cuidados prestados. $O$ exercício de cuidar e ver o reflexo desta atividade incidindo na melhora e alta deste paciente; novamente, reforça a idéia da paixão pela profissão, e da importância da transformação do objeto de trabalho - entendida como uma 
alteração da situação atual das condições de saúde do paciente para o melhor estágio saudável possível.

A satisfação do paciente e familiares com a assistência recebida desencadeia a satisfação por parte daqueles que prestaram esta assistência. Da mesma forma, quando o objetivo não é alcançado, ou seja, quando o paciente não responde positivamente às intervenções realizadas, seja pela piora ou morte, ocorre o entristecimento dos trabalhadores, fato que, isoladamente, compromete o desenvolvimento ou manutenção da QVT.

Concomitantemente à recompensa individual de ver o paciente com suas condições de saúde restabelecidas, o reconhecimento deste mesmo paciente ao trabalho realizado, atua como recompensa aos trabalhadores que nem sempre correspondem às demandas existentes. Junto a este reconhecimento, as falas também evidenciam a formação de uma identidade pessoal e social. O reconhecimento do trabalhador como sendo um profissional da área da saúde, confere-lhe uma identidade junto à população atendida que, segundo os relatos dos próprios trabalhadores, motiva-os para que continuem atuando na área assistencial. Diferentemente das demais colocações frente ao objeto de trabalho, Edward Elgar demonstra sua motivação advinda pelo reconhecimento dos demais trabalhadores ao seu trabalho.

Também foi possível apreender que alguns trabalhadores atuam em sua área de preferência, como unidade pediátrica ou neonatológica. Este fator, isoladamente, contribui para que o profissional consiga obter maior 
satisfação no trabalho, uma vez que, além do prazer de exercer a profissão escolhida, ele pode fazê-la com o público que mais se identifica.

Um outro elemento citado pelos participantes e que, de alguma forma, reflete no aspecto organizacional do processo de trabalho, é a motivação pelo convívio com a equipe de trabalho (tanto equipes de enfermagem quanto médicas). É interessante observar a identificação com o ambiente de trabalho e com os demais trabalhadores, que, por vezes, os trabalhadores definem como "lar". Isto identifica nas falas a alegria em trabalhar por saber, que o local de trabalho, proporcionará momentos de descontração com os demais membros da equipe, mesmo na tensão imposta pela própria jornada de trabalho.

Padilha e Souza (1999) encontraram que a qualidade de vida das enfermeiras é motivada pelo valor que elas atribuem às relações pessoais no trabalho, na família, nas amizades e na possibilidade de o trabalho representar uma forma de vida produtiva. A possibilidade de gregarismo humano presente no ambiente de trabalho e a satisfação do feed back junto ao paciente (seja pela cura, pela melhora ou por um simples sorriso) permite o estabelecimento de relacionamentos de confiança, de forma que a esfera laboral passa a ser potencializada, quando ocorre a frustração na esfera familiar. Desta maneira, o trabalho passa a ser o espaço que favorece o desenvolvimento das capacidades humanas, que conseqüentemente traz melhorias na qualidade de vida.

Os participantes referem que, em algumas circunstâncias, o ambiente de trabalho é preferível ao ambiente familiar, devido aos problemas 
enfrentados na vida pessoal. Isto traz à tona que o ambiente de trabalho, apesar dos contravalores, apresenta-se como um abrigo para os trabalhadores, um lugar que lhes confere segurança e sentimento de pertença ao grupo. Nas falas, o contraponto das adversidades na área familiar estava no trabalho, já que, pelo reconhecimento dos pacientes e pelo próprio ambiente de trabalho, os momentos de tranqüilidade e alegria resumiam-se ao turno de trabalho.

Erik Satie retrata uma situação em que estava em licença médica por problemas de saúde; entretanto, o isolamento do meio social de trabalho agravava a situação a tal medida que ele retornou ao trabalho em tempo inferior ao estabelecido pelo atestado. Com isto, pode-se apreender a importância do trabalho na vida das pessoas e como a privação do mesmo, ainda que por motivos de doença, comprometem o estado psicoemocional dos trabalhadores. Talvez esta seja uma das respostas que justifiquem a permanência destes profissionais no ambiente de trabalho, mesmo quando em processo de desgaste do corpo físico e mental.

Schimdt e Dantas (2006), em estudo realizado para análise da QVT com enfermeiros de bloco cirúrgico, sobe a ótica da satisfação, medida através do Índice de Satisfação Profissional (ISP), encontram como maior fonte de satisfação o status profissional, entendido como o reconhecimento da importância da profissão - percepção semelhante a dos participantes deste estudo.

Silva e Massarollo (1998) afirmam que a QV dos trabalhadores de enfermagem é dependente do modo como o trabalho se organiza e se opera 
e de como os profissionais utilizam as estratégias de enfrentamento. Nas falas referidas, os fatores motivadores aos trabalhadores de enfermagem podem ser compreendidos como estratégias de enfrentamento frente às adversidades presentes no ambiente de trabalho, porque, apesar delas, os profissionais mantém-se ativos e esta manutenção, de alguma forma, é um enfrentamento da realidade. Assim, eles buscam na satisfação profissional um mecanismo compensatório ao desgaste gerado pelo trabalho.

\subsection{3 - Ações direcionadas à QVT}

Posterior a apreensão do significado de QVT e da motivação para o trabalho, buscou-se compreender quais ações eram desenvolvidas, tanto pelos trabalhadores como pelos enfermeiros, quanto institucional, que promovesse a QVT.

"... mas vocês mesmo (refere-se aos gerentes) conseguiram pra gente um psicólogo, o que ajudou muito a gente lá na UTI..." (Joseph Haydn)

“... conseguimos detectar que ele tinha problemas seríssimos na família, tivemos que encaminhar pra psicóloga, o funcionário teve que ser afastado..." (Giacomo Puccini)

“... a nossa chefe, ela conversa demais, nós temos terapeuta ocupacional, psicóloga tem 12 horas, nós temos psicóloga lá e os alunos (...) são pros pacientes e, às vezes, acaba sendo pra nós também (...) isso ajuda muito a descarregar..." (Rossini)

"... a gente tem atendimento de psicólogo lá no meu setor (SESMT) que fica disponível para as pessoas procurarem." (Edward Elgar)

"... como não tem psicólogos em todos os setores, a gente faz um café da manhã, reúne o pessoal, faz uma oração..." (Mendelsonn)

"... pra mim a instituição não faz nada!" (Amadeus Mozart) 
“... não ta dando nada não! (refere-se à instituição) $O$ negócio aqui é cobrar, cobrar em cima do que você tem, se vira, e isso é ruim! Como eu vou falar pro meu pessoal: se vira? Só se eu for lá e me virar com eles..." (John S. Bach)

Em relação às possíveis ações realizadas no hospital, direcionadas à promoção da QVT, as falas demonstraram o não reconhecimento de qualquer tipo de atuação, que favoreça à saúde dos trabalhadores de enfermagem. Os trabalhos percebem o descaso da Instituição frente a esta abordagem. Além disso, referem que o hospital assume uma postura passiva frente às necessidades apresentadas pela enfermagem, transferindo sua responsabilidade ao responsável pela Divisão de Enfermagem, para que este dê conta das demandas com o que lhe é disponível.

No entanto, referem que o único serviço que atua junto ao trabalhador de enfermagem é o SESMT, na figura do enfermeiro do trabalho. Este serviço disponibiliza psicólogos e profissionais das áreas básicas da medicina para a realização dos exames periódicos, atendimento aos trabalhadores acidentados e outros atendimentos à saúde, mediante agendamento.

A disponibilização deste serviço aos trabalhadores não é por eles destacada, uma vez que isto está garantido pela Lei 6.514 , de 22 de dezembro de 1977, que altera Capítulo V da Consolidação das Leis do trabalho e institui, em seu Art. 162 a criação do Serviço Especializado em Segurança e Medicina do Trabalho (SESMT) e, como órgão complementar, institui a Comissão Interna de Prevenção de Acidentes de Trabalho (CIPA), em todos os estabelecimentos que possuírem funcionários contratados pelo regime CLT. Apesar de não de o HUdE não se enquadrar nesta legislação 
(já que o vínculo de contratação é o RJU), as instituições públicas buscam seguir o proposto pela CLT aos seus trabalhadores. Assim, este serviço caracteriza-se como um cumprimento a uma normatização estabelecida, e não uma iniciativa institucional sistematizada, direcionada à saúde dos trabalhadores.

Em 06 de outubro de 2006 foi lançada a Portaria $n^{\circ}$. 1.675, que dispõe sobre orientações e padronizações quando aos serviços de saúde e a saúde dos servidores públicos federais - regulamentação vai ao encontro da a postura adotada pelo Hospital.

Além disso, o SESMT destina-se à assistência posterior ao acontecimento do acidente ou desgaste; o trabalhador só vai até ele para a realização dos exames periódicos, quando da notificação de algum acidente de trabalho ou quando do desgaste (solicitação de afastamento por doença ou outro motivo). Segundo informações coletadas junto ao enfermeiro do trabalho, o SESMT desenvolvia algumas atividades orientativas aos trabalhadores do hospital em parceria com a CIPA e Educação Continuada, mas, com a extinção da CIPA pela atual diretoria, este trabalho não teve continuidade.

A inexistência de ações institucionais que promovam a saúde ou favoreça a qualidade de vida no ambiente de trabalho, confere maior visibilidade às ações pontuais e direcionadas desempenhadas pelos enfermeiros responsáveis pelos setores. As falas demonstraram as conquistas dos enfermeiros gerenciais para sua equipe, como a presença de psicólogos em alguns setores. No caso da UTI, a presença de docentes e 
alunos de psicologia destina-se ao atendimento ao paciente e familiares; entretanto, os profissionais também fornecem apoio aos trabalhadores, seja quando solicitados ou por algum interesse motivado por determinada situação geradora de estresse à equipe.

De alguma forma, os enfermeiros buscam individualmente dar conta da demanda de sua equipe, no que se refere ao perfil de saúde e doença no ambiente de trabalho. Outras ações apontadas são os momentos de integração, como lanches e cafés da manhã, e os momentos de orações, o que aponta para a religiosidade como uma estratégia de enfrentamento. Essa estratégia, também, é apontada por Gutierrez (2003), em seu estudo sobre o processo de morrer no cotidiano do trabalho de enfermagem.

As falas evidenciam que os enfermeiros, no gerenciamento de recursos humanos, buscam manter contato com os membros da equipe de enfermagem, como uma estratégia para identificar possíveis necessidades e problemas de saúde e, assim, buscar alternativas para solução (que, em grande parte das vezes, acaba sendo o encaminhamento a algum serviço de apoio). Segundo Campos (1997) a qualidade em saúde está calcada na adequada combinação de autonomia profissional com certo grau de definição de responsabilidade para os trabalhadores. Ou seja, no compartilhamento mútuo de responsabilidades entre os membros da equipe, de forma que seja garantida tanto a qualidade do atendimento para os pacientes e familiares quanto à qualidade de vida para os trabalhadores.

O terceiro lado do triângulo que também deve assumir responsabilidades quando à promoção de um ambiente de trabalho saudável 
é a própria organização. As falas demonstraram a inoperância do Hospital quanto às questões relacionadas à qualidade de vida no trabalho. Matos (1999), em sua pesquisa sobre a reflexão da qualidade de vida no trabalho da enfermagem em uma instituição hospitalar, conclui que a construção da qualidade de vida no ambiente de trabalho exige um esforço coletivo de trabalhadores e instituição, sendo os trabalhadores no repensar sobre os processos de trabalho e a instituição na implementação de medidas que contribuam para a promoção da QVT.

Acerca do processo gerencial, Felli (2002) descreve que ele está imbuído de muitas possibilidades de intervenções e transformações que objetivam a melhoria das condições de trabalho, com vistas à qualidade de vida dos pacientes e dos trabalhadores de enfermagem. É, portanto, instrumento necessário à implementação de políticas institucionais que abarquem as questões da saúde no trabalho.

\subsection{Processos favoráveis}




\section{A QVT decorre de}

processos favoráveis à saúde dos trabalhadores no momento de trabalho. As falas dos participantes, apesar de enfatizarem os processos destrutivos, possibilitaram a evidência de alguns fatores que favorecem a promoção da qualidade de vida:

“... você viu a satisfação do paciente quando está conosco, a alegria dele quando nos vê, parece que a gente tem o poder da cura nas mãos, impressionante!" (Erik Satie)

“... é muito bom o relacionamento com todos, a divisão é muito boa, não é só feito com a minha chefia, são feitos com nosso grupo ali mesmo (...) Eu acho que quando você consegue mostrar algo para a pessoa que precisa mudar, quando a gente se reúne em prol uma coisa e consegue mudar (...) dessa maneira, nós conseguimos mudar uma coisa que era muito desgastante e a gente queria mudar pra melhore acho que a gente conseguiu! "(Rossini)

“... a gente tem uma interação muito gostosa também, a equipe de enfermagem, os pacientes (...) eu sinto que sou muito valorizada pela minha equipe, eu abro espaço pra eles crescerem, eles trazem sempre coisas novas, e a gente vai discutindo..." (Amadeus Mozart)

“... nós aprendemos muito naquele lugar (...) pra melhorar o ambiente de trabalho, os próprios funcionários fizeram uma reforma, nó humanizamos bastante e agora a unidade tá bonitinha..." (Rossini)

“... nós intervimos em algumas situações e conseguimos mudar algumas situações de trabalho adaptar algum servidor que estava doente..." (Edward Elgaro)

As falas demonstraram a presença de variáveis que contribuem para o desenvolvimento e manutenção de um ambiente de trabalho saudável, que reflete diretamente no favorecimento da qualidade de vida. Entretanto, a posição do grupo foi bastante tímida quanto aos apontamentos 
dos processos favoráveis contrapondo-se com a agressividade implícita nas falas referentes ao processo destrutivo.

Os processos favoráveis apresentados pelos sujeitos do estudo assemelharam-se aos fatores motivadores no ambiente de trabalho. De forma a evitar a duplicidade de informações, as falas supra-referidas diferem e complementam os aspectos que motivam os profissionais a comparecerem cotidianamente em seu trabalho, pois a QVT está intimamente ligada aos processos favoráveis e motivadores no trabalho - já que decorre deles.

O reconhecimento e a valorização conquistados pelo profissional junto aos pacientes e familiares colaboram para a satisfação do trabalhador . Observa-se, novamente, que a importância conferida ao objeto de trabalho e a confiabilidade mútua estabelecida nas relações colaboram para a qualidade de vida do trabalhador. Se, por um lado, este objeto de trabalho é, em si, gerador de desgaste do trabalhador, ele também pode representar o retorno às expectativas imbuídas no cuidado, ainda que inconscientemente. Esta retribuição deliberada, apesar de não se caracterizar como uma ação direcionada a QVT, age como tal, pois corresponde às expectativas dos trabalhadores.

As falas evidenciaram que há o compartilhamento do poder entre enfermeiro e demais membros da equipe, em algumas esferas de decisão. A importância percebida por Rossini (auxiliar de enfermagem) ao sentir-se como parte das decisões, tomadas na unidade, insere-o em um contexto onde ele deixa de apenas de cumprir e passa, também, a decidir. Esta oportunidade de participação, onde ocorre a socialização do poder decisório, 
favorece o desenvolvimento da qualidade de vida, sentida pelos demais trabalhadores da equipe.

Outro fator citado está associado à capacidade de organização dos trabalhadores em prol a um objetivo comum. Confrontar opinião com outro profissional (em especial, o profissional médico) e tentar convencê-lo de quem nem sempre seu ponto de análise representa o mais apropriado para o momento e que há discordância na equipe, nem sempre possibilita resultados. Contudo, quando este movimento deixa de ser individual e passa a ser coletivo, o poder de argumentação e de barganha torna-se maior e, portanto, as chances de consenso, também, aumentam. Os participantes mostraram que, quando as forças movem-se unidirecionalmente, as situações em que ocorre o desgaste podem ser revertidas em favoráveis à sua saúde.

Uma outra fala, colocada por Amadeus Mozart (enfermeira chefe de unidade), refere sua satisfação frente à valorização conquistada na equipe e a contrapartida por ela oferecida, na relação de reciprocidade com os outros trabalhadores. Assim, numa relação de causa e efeito (sem o conhecimento de qual necessariamente é a causa e qual é o efeito) tem-se uma enfermeira que incentiva e facilita o crescimento profissional de sua equipe e a equipe reconhece e valoriza a postura profissional da enfermeira por esta e outras iniciativas.

Esta mesma fala, também, evidencia a autonomia conferida aos membros da equipe, que podem trazer questionamentos ou novas informações para serem discutidas em equipe. Esta troca de conhecimentos, 
de forma horizontalizada, permite a construção de conceitos de trabalho calcados na participação, discussão e consensos em equipe.

A oportunidade de aprendizagem oferecida aos trabalhadores no ambiente de trabalho também foi apontada como um dos fatores favorecedores da saúde no trabalho. Silva e Massarollo (1998) consideram que, no momento produtivo, um perfil favorável pode ser apreendido pela possibilidade de integração social e gregarismo humano; aprendizagem, formação de uma identidade social e pessoal; desenvolvimento e utilização de capacidades humanas.

Elias e Navarro (2006), em estudo realizado sobre a negatividade e positividade da relação trabalho, saúde e condições de vida entre os trabalhadores de enfermagem hospitalares, encontraram resultados semelhantes às falas dos sujeitos do presente estudo. Assim, as autoras evidenciaram nas falas que, apesar de ser desgastante, o trabalho é percebido de forma positiva. A possibilidade de ajudar o próximo, a execução de algo valorizado e reconhecido socialmente, bem como o prazer e a gratificação do trabalho foram fatores que minimizam as perdas, inclusive financeiras, como referiram os participantes do estudo.

Ou seja, a enfermagem busca amparar-se na satisfação proporcionada pela interação com o paciente para compensar 0 desequilíbrio presente no ambiente de trabalho, de forma que, a sensação de prazer quando da interação com o objeto de trabalho, supere as frustrações oriundas da relação com os meios, instrumentos e organização. 


\subsection{Processos destrutivos}

Os processos destrutivos aos quais os trabalhadores de enfermagem estão expostos no trabalho e o desgaste decorrente destes foram subdivididos de acordo com o tipo de carga de trabalho a que o profissional foi exposto. Para a definição das cargas, utilizaremos a conceituação dada por Silva (1996).

\subsubsection{Cargas biológicas}

Consideram-se como cargas biológicas 0 contato com pacientes portadores pacientes de doenças infecciosas e infectocontagiosas e/ou com suas secreções; a manipulação de materiais contaminados; a presença de pequenos animais (Silva, 1996). Assim, são apresentadas no quadro a seguir. 
Quadro VI - Caracterização da exposição dos trabalhadores de enfermagem do Hospital Universitário de Estudo às cargas biológicas de trabalho, segundo a unidade de trabalho, atividades realizadas e desgastes desencadeados por esta exposição. HUdE, 2006.

Tipos de cargas Unidades expostas

\begin{tabular}{|c|c|c|c|}
\hline \multicolumn{4}{|l|}{$\begin{array}{l}\text { Cargas } \\
\text { Biológicas }\end{array}$} \\
\hline $\begin{array}{l}\text { Manipulação de } \\
\text { pacientes } \\
\text { portadores de } \\
\text { doenças } \\
\text { infecciosas, } \\
\text { infecto- } \\
\text { contagiosas e } \\
\text { parasitárias }\end{array}$ & $\begin{array}{l}\text { PSI } \\
\text { Urodinâmica } \\
\text { Cirurgia Pediátrica } \\
\text { CTI } \\
\text { UTI neonatal } \\
\text { Medicina do Trabalho } \\
\text { Quimioterapia Ambulatorial } \\
\text { Pediatria } \\
\text { Clínica Médica } \\
\text { SPA } \\
\end{array}$ & $\begin{array}{l}\text { Assistência de pacientes com Pneumonia, } \\
\text { Meningite,Tuberculose e SIDA; punção venosa; punção de } \\
\text { cateteres; assistência no banho; administração de } \\
\text { medicamentos; aspiração orotraqueal; passagem de sonda; } \\
\text { troca de curativos; esvaziamento de coletores; auxílio em } \\
\text { mielogramas; realização de procedimentos; mudança de } \\
\text { decúbito; troca de fraldas; coleta de escarros, hemocultura, } \\
\text { sangue; cuidados ao paciente, contato com secreções. }\end{array}$ & $\begin{array}{l}\text { Problemas psíquicos; } \\
\text { problemas } \\
\text { psicológicos; estresse; } \\
\text { baixa imunidade; } \\
\text { doenças; lesão } \\
\text { percutânea; micose } \\
\text { nas unhas; dermatite, } \\
\text { virose; doenças } \\
\text { transmissíveis pelo } \\
\text { contato. } \\
\end{array}$ \\
\hline $\begin{array}{l}\text { Manipulação de } \\
\text { material } \\
\text { contaminado }\end{array}$ & $\begin{array}{l}\text { PSI } \\
\text { Urodinâmica } \\
\text { Cirurgia Pediátrica } \\
\text { CTI } \\
\text { UTI Neonatal Quimioterapia } \\
\text { Ambulatorial Pediatria } \\
\text { Clínica Médica } \\
\text { SPA }\end{array}$ & $\begin{array}{l}\text { Sondagem vesical; dilatação uretral; administração de } \\
\text { medicamentos; curativos; retirada de punção venosa; frasco de } \\
\text { aspiração; troca de fralda; material de dissecção; seringas, } \\
\text { scalps, cateteres, gazes; coleta de exames; lavagem de } \\
\text { materiais; punção de acesso profundo; dreno de tórax; } \\
\text { traqueostomia; procedimentos cirúrgicos; limpeza de material. }\end{array}$ & $\begin{array}{l}\text { Doenças; acidentes de } \\
\text { trabalho; virose; } \\
\text { dermatite; risco de } \\
\text { acidente e doenças de } \\
\text { trabalho. }\end{array}$ \\
\hline
\end{tabular}


Os dados demonstram que todos os trabalhadores das unidades assistenciais estão expostos às cargas biológicas no trabalho. A exposição dos trabalhadores a este tipo de carga ocorre, especialmente, quando da ocorrência de acidentes com perfuro-cortantes, causa principal dos acidentes de trabalho notificados no HUdE. Os instrumentos que provocam este tipo de acidente geralmente são contaminados, ou seja, contém algum tipo de material biológico por ter entrado em contato com o paciente.

O próprio contato com o paciente na assistência do cuidado expõe este trabalhador ao contato com secreções e fluídos corpóreos, seja na realização de procedimentos, na coleta de materiais para exames, na administração de medicamentos ou qualquer outra atividade assistencial, conforme referido nas falas. Os sujeitos enfatizaram o cuidado prestado aos pacientes portadores de doenças infecto-contagiosas como pneumonia, meningite, tuberculose e AIDS, já que estes são fontes conhecidas de doenças transmissíveis pelo contato com secreções.

As falas dos participantes do grupo focal evidenciaram a presença de insetos nocivos no ambiente de trabalho:

\footnotetext{
“... esses pequenos insetos aqui podia ser o mosquito da Dengue que tem um monte aqui! Não dá nem pra trabalhar a noite de tantos mosquitos..." (Pachebel)

“... mosquito da Dengue dentro do hospital tem também um monte!" (Erik Satie)
}

Evidencia-se, a partir dos relatos acima, condições de trabalho que comprometem a saúde e proporcionam risco de desenvolvimento de doenças, o desconforto e irritação decorrentes do contato com os insetos. Os desgastes gerados por esta exposição estão relacionados ao aparelho 
físico - no que re refere às patologias adquiridas, micoses, dermatites, viroses, alergias, picadas - e no psíquico, gerado especialmente pelo estresse. $\mathrm{O}$ envenenamento decorrente da picada de pequenos animais foi citado como um possível desgaste decorrente desta exposição, apesar de ninguém ter sofrido tal situação.

Bálsamo e Felli (2006), Canini, Gir, Machado (2005), Marziale, Nishimura, Ferreira (2004), Canini, Gir, Hayashida, Machado (2002) demonstraram que a maior parte dos acidentes com material biológico ocorre pelo contato com agulhas e outros materiais perfuro-cortantes contaminados e descartados em locais inapropriados, sendo a infecção ocupacional por AIDS e hepatites uma decorrência concreta.

Almeida, Pagliuca, Leite (2005) estudaram o acidente de trabalho envolvendo os olhos e encontraram que os materiais biológicos, especialmente o sangue, apesar de não ser a principal causa de exposição, é a que demanda atendimento imediato, devido ao elevado risco de infecção por patógenos. Apesar deste tipo de acidente ter sido referenciado como causa nas notificações internas de acidentes de trabalho (CIATs), não houve referência da exposição de mucosas a fluídos ou secreções corporais.

\subsubsection{Cargas Químicas}

Consideram-se cargas químicas a exposição do trabalhador às substâncias químicas e medicamentosas, gases anestésicos, poeiras, fumaças, exposição a materiais de borracha (Silva, 1996). 
Quadro VII - Caracterização da exposição dos trabalhadores de enfermagem do Hospital Universitário de Estudo às cargas químicas de trabalho, segundo a unidade de trabalho, atividades realizadas e desgastes desencadeados por esta exposição. HUdE, 2006.

\begin{tabular}{|c|c|c|c|}
\hline Tipos de cargas & Unidades expostas & Atividades expostas & Desgastes gerados \\
\hline \multicolumn{4}{|l|}{ Cargas Químicas } \\
\hline $\begin{array}{l}\text { Manipulação e } \\
\text { inalação de } \\
\text { substâncias } \\
\text { químicas }\end{array}$ & $\begin{array}{l}\text { PSI } \\
\text { Urodinâmica } \\
\text { Cirurgia Pediátrica } \\
\text { CTI } \\
\text { UTI neonatal } \\
\text { Medicina do Trabalho } \\
\text { Quimioterapia Ambulatorial } \\
\text { Pediatria } \\
\text { Clínica Médica }\end{array}$ & $\begin{array}{l}\text { Administração de medicamento intravesical } \\
\text { (BCG, DMSO); lavagem e preparo de } \\
\text { materiais; preparo de medicamentos; } \\
\text { organização do setor; limpeza, desinfecção e } \\
\text { esterilização de materiais hospitalares; } \\
\text { administração de quimioterápicos e } \\
\text { antibióticos; sedação; instalação de } \\
\text { quimioterapia. }\end{array}$ & $\begin{array}{l}\text { Desgaste psíquico; } \\
\text { tosse; dispnéia; } \\
\text { problemas alérgicos, } \\
\text { urticária; } \\
\text { hipersensibilidade } \\
\text { cutânea à } \\
\text { administração do MTX; } \\
\text { resistência. }\end{array}$ \\
\hline $\begin{array}{l}\text { Manipulação de } \\
\text { medicamentos }\end{array}$ & $\begin{array}{l}\text { PSI } \\
\text { Urodinâmica } \\
\text { Cirurgia Pediátrica } \\
\text { CTI } \\
\text { UTI Neonatal } \\
\text { Quimioterapia Ambulatorial }\end{array}$ & $\begin{array}{l}\text { Assistência de enfermagem em PSI e } \\
\text { urodinâmica; preparo e administração de } \\
\text { quimioterápicos e outras drogas; preparação e } \\
\text { administração de medicação. }\end{array}$ & $\begin{array}{l}\text { Manchas na pele; } \\
\text { aumento de mioma; } \\
\text { baixa da imunidade; } \\
\text { resistência bacteriana; } \\
\text { resistência a ação de } \\
\text { antibióticos. }\end{array}$ \\
\hline $\begin{array}{l}\text { Inalação de fumaça } \\
\text { de cigarro }\end{array}$ & Divisão de Enfermagem & Durante as reuniões & Alergia \\
\hline
\end{tabular}


As cargas químicas também estão presentes em todos os setores de trabalho, tanto assistencias quanto educativos. As atividades em que ocorre a exposição estão relacionadas ao preparo e administração de medicamentos, limpeza e desinfecção de materiais, equipamentos e espaço físico de trabalho e durantes reuniões. Os desgastes gerados, também, afetam o aparelho psíquico, devido ao medo e estresse desencadeado pelo risco de acidentes; e a saúde física, com o aparecimento de sinais e sintomas, como dispnéia, alergias, tosse, urticárias, hipersensibilização e multi-resistência antibiótica.

Os sujeitos, ainda, referem a falta de atenção e cuidado no preparo de medicamentos, bem como a inadequação de instrumentos e local para a realização desta atividade.

\footnotetext{
“... quando eu trabalhava na enfermaria, nós preparávamos a quimioterapia na enfermaria, sem nenhuma proteção e fazíamos quimioterapia como se faz qualquer medicação, né? Ninguém usava capote, nem nada..." (Orlando Gibbons)

“... continuam manipulando na lavanderia o hipoclorito de sódio, o formaldeído, o fenol sintético sem equipamento de proteção individual (...) nós trabalhávamos no centro cirúrgico, o lugar mais inadequado era onde ficava localizado o recipiente grande com glutaraldeído, dentro da sala de recuperação." (Erik Satie)
}

As transcrições acima permitem verificar que o trabalhador, pelo próprio ritmo acelerado de trabalho e pela falta de condições adequadas para a realização dos procedimentos, tem sua exposição potencializada aos fatores destrutivos da saúde. Muitas vezes, devido às situações emergenciais, prevalece o "instinto" de assistir, em detrimento da sua preservação pela obediência às normas de precaução padrão. Por outro lado, às vezes, a própria estrutura física é comprometedora, desencadeando 
a utilização de espaços comuns para objetivos diferentes (como a sala de recuperação para 0 atendimento pós-cirúrgico sendo utilizada para o depósito do recipiente com substância química para desinfecção). Em relação à fumaça de cigarro, os participantes referiram que há um local específico para a prática deste hábito (denominado fumódromo); todavia, nas reuniões de equipe (que ocorrem externamente da unidade assistencial), o hábito ocorre fora do local reservado.

O estudo realizado por Almeida, Pagliuca, Leite (2005) encontra como causa principal de acidente em mucosa ocular o manuseio de substâncias químicas. Xalengati, Robazzi, Marzialle, Haas (2006); Costa e Felli (2005) referem a exposição às cargas químicas, como sendo a principal causadora de problemas de pele, do aparelho respiratório e imunológico, e reações alérgicas. Estes desgastes também são referidos pelos trabalhadores do HUdE. Ambos trabalhos destacam a importância da educação continuada no serviço, seja por meio da SESMT ou pelo Serviço de Educação Continuada do hospital.

\subsubsection{Cargas físicas}

Consideram-se, dentre outras, como cargas físicas a exposição do trabalhador ao ruído excessivo, a umidade, a iluminação, a mudanças bruscas de temperatura, a eletricidade e a radiação ionizante (Silva, 1996), os trabalhadores consideram-se expostos, como pode ser visualizado no quadro a seguir. 
Quadro VIII - Caracterização da exposição dos trabalhadores de enfermagem do Hospital Universitário de Estudo às cargas físicas de trabalho, segundo a unidade de trabalho, atividades realizadas e desgastes desencadeados por esta exposição. HUdE, 2006.

\begin{tabular}{|c|c|c|c|}
\hline Tipos de cargas & Unidades expostas & Atividades expostas & Desgastes gerados \\
\hline \multicolumn{4}{|l|}{ Cargas Físicas } \\
\hline $\begin{array}{l}\text { Radiação } \\
\text { lonizante }\end{array}$ & $\begin{array}{l}\text { Cirurgia Pediátrica } \\
\text { CTI } \\
\text { UTI Neonatal } \\
\text { Divisão de Enfermagem } \\
\text { Pediatria } \\
\text { SPA }\end{array}$ & $\begin{array}{l}\text { Acompanhamento de pacientes nos exames; } \\
\text { realização do } \mathrm{RX} \text { diário; } \mathrm{RX} \text { no leito; trabalho } \\
\text { próximo da radiologia. }\end{array}$ & $\begin{array}{l}\text { Alteração de HC; } \\
\text { diminuição cálcio; mutação } \\
\text { celular que gera } \\
\text { malformação. }\end{array}$ \\
\hline $\begin{array}{l}\text { Radiação não } \\
\text { lonizante }\end{array}$ & $\begin{array}{l}\text { UTI Neonatal } \\
\text { Divisão de Enfermagem }\end{array}$ & $\begin{array}{l}\text { Realização de exames de tomografia, ecografia, } \\
\text { ecocardiograma; trabalho com muita luz } \\
\text { florescente. }\end{array}$ & $\begin{array}{l}\text { Desgaste físico; estresse; } \\
\text { manchas na pele. }\end{array}$ \\
\hline Ruído & $\begin{array}{l}\text { Cirurgia Pediátrica } \\
\text { CTI } \\
\text { Pediatria } \\
\text { Clínica Médica } \\
\text { SPA }\end{array}$ & $\begin{array}{l}\text { Reforma dos setores; caldeira; oxímetro de } \\
\text { pulso; monitores; bomba de infusão; alarmes dos } \\
\text { equipamentos; ruídos advindos do lado externo } \\
\text { do CTI; gritos das crianças durante } \\
\text { procedimentos dolorosos; aparelhos que fazem } \\
\text { muito barulho; fluxo de pessoas; respiradores; } \\
\text { pacientes, acompanhantes, residentes, médicos, } \\
\text { todos falando ao mesmo tempo. }\end{array}$ & $\begin{array}{l}\text { Irritação; dor de cabeça; } \\
\text { surdez; ruído no ouvido; } \\
\text { agitação ao dormir; } \\
\text { dificuldade para ouvir; } \\
\text { perda da audição. }\end{array}$ \\
\hline Umidade & $\begin{array}{l}\text { Cirurgia Pediátrica } \\
\text { Clínica Médica }\end{array}$ & $\begin{array}{l}\text { Inundação da clínica em tempos de chuva; } \\
\text { alguns leitos com umidade interna. }\end{array}$ & Gripe; irritação. \\
\hline $\begin{array}{l}\text { Mudança de } \\
\text { temperatura }\end{array}$ & $\begin{array}{l}\text { Cirurgia Pediátrica } \\
\text { UTI Neonatal } \\
\text { Quimioterapia Ambulatorial } \\
\text { Divisão de Enfermagem }\end{array}$ & $\begin{array}{l}\text { Sala de RX e ecografia; TC - na saída do setor } \\
\text { (o setor é quente e quando saímos nos } \\
\text { deparamos com o frio); lugares com e sem ar } \\
\text { condicionado; o próprio ambiente de trabalho. }\end{array}$ & $\begin{array}{l}\text { Gripe; irritação; problemas } \\
\text { respiratórios; resfriados; } \\
\text { dores pelo corpo. }\end{array}$ \\
\hline
\end{tabular}


Quadro VIII - Caracterização da exposição dos trabalhadores de enfermagem do Hospital Universitário de Estudo às cargas físicas de trabalho, segundo a unidade de trabalho, atividades realizadas e desgastes desencadeados por esta exposição. HUdE, 2006. (continuação)

\begin{tabular}{|c|c|c|c|}
\hline Tipos de cargas & Unidades expostas & Atividades expostas & Desgastes gerados \\
\hline \multicolumn{4}{|l|}{ Cargas Físicas } \\
\hline $\begin{array}{l}\text { Eletricidade } \\
\text { (choque elétrico) }\end{array}$ & $\begin{array}{l}\text { PSI } \\
\text { Urodinâmica } \\
\text { UTI Neonatal } \\
\text { CTI } \\
\text { Cirurgia Pediátrica } \\
\text { Pediatria }\end{array}$ & $\begin{array}{l}\text { Supervisão e troca de eletrodos do bisturi; ligar } \\
\text { o mergulhão; manipulação de equipamentos } \\
\text { elétricos do setor; manipulação e limpeza de } \\
\text { materiais como bomba de infusão, oxímetros e } \\
\text { outros; manipulação das bombas de infusão e } \\
\text { monitores; aquecimento de água com } \\
\text { mergulhão. }\end{array}$ & $\begin{array}{l}\text { Choque e queimadura; } \\
\text { tensão; medo de } \\
\text { morrer eletrocutado; } \\
\text { até perda de membros. }\end{array}$ \\
\hline Risco de incêndio & $\begin{array}{l}\text { Cirurgia Pediátrica } \\
\text { CTI } \\
\text { Divisão de Enfermagem }\end{array}$ & $\begin{array}{l}\text { Desligar o mergulhão depois de pegar fogo; } \\
\text { existência de tubulação de gases e aparelhos } \\
\text { elétricos; presença de muitos papéis e } \\
\text { materiais inflamáveis; lidar com gases } \\
\text { inflamáveis e materiais antigos (sob risco de } \\
\text { curto-circuito); gás canalizado. }\end{array}$ & Tensão; medo. \\
\hline
\end{tabular}


As cargas físicas, semelhantemente, às demais cargas, também estão presentes em todas as unidades assistenciais e de diagnose. O quadro acima faz referência a algumas atividades evidenciadas pelos participantes, nas quais ocorre esta exposição. Os exames de imagens, presentes especialmente na unidade de centro cirúrgico, são a principal causa da exposição ionizante e não ionizante, sendo as ações celulares e genéticas o desgaste referido pelos participantes. As recorrentes reformas nos setores, 0 barulho dos equipamentos (citados por todos os trabalhadores da UTI) e os sons vocais dos pacientes e familiares (enfatizado pelos profissionais da área pediátrica) são a principal causa do ruído, responsável pela irritação, dor de cabeça, distúrbio do sono, diminuição e, inclusive perda, da capacidade auditiva. A umidade é caracterizada pelas inundações decorrentes das alterações climáticas e mudanças de temperatura, pela alternância de ambientes, durante a jornada de trabalho, sendo ambas as cargas geradoras de gripe, irritação, problemas respiratórios e dores pelo corpo.

A exposição à eletricidade foi reconhecida pela manipulação de materiais elétricos, necessário para a prestação da assistência, bem como pelas múltiplas funções desempenhadas pelos trabalhadores de enfermagem, especialmente, na unidade de centro cirúrgico. A fim de evitarem o estresse da equipe médica e o comprometimento do ato cirúrgico, assumem a função de eletricista e acabam por consertar equipamentos que apresentam falhas durante o procedimento. Isto gera o risco de choques e queimaduras, além do medo e tensão do trabalhador de sofrer algum tipo de dano. Este desgaste se repete quanto ao risco de incêndio, devido à presença de gases inflamáveis e 
materiais antigos e em péssimas condições de uso, o que potencializa a sensação de medo dos trabalhadores quando da execução de suas ações.

Nishide e Benatti (2004) referem a exposição diária às radiações ionizantes emitidas pelos aparelhos de raio-x em unidades de terapia intensiva, o risco de quedas (carga fisiológica) decorrente de ambientes úmidos ou molhados (carga física) e o desconforto térmico e iluminação inadequada como fatores de risco para acidentes. As autoras ainda evidenciaram que os níveis de ruídos são poucos percebidos pelos trabalhadores de UTI como fatores de risco para a saúde.

Cruz (2006) menciona a exposição ao ruído sendo causada, especialmente, pelos equipamentos utilizados na rotina de trabalho e nos sons emitidos pelos próprios pacientes e acompanhantes. Também aponta para os riscos de choque elétrico, que o trabalhador de enfermagem está exposto, por ser o trabalhador responsável pela manipulação de equipamentos e aparelhos elétricos.

\subsubsection{Cargas mecânicas}

As cargas mecânicas ocorrem quando há a manipulação de materiais cortantes ou pontiagudas, quedas, agressões e possibilidades de preensões de partes do corpo (Silva, 1996). A exposição dos trabalhadores de enfermagem do HUdE, é mostrada no quadro a seguir. 
Quadro IX - Caracterização da exposição dos trabalhadores de enfermagem do Hospital Universitário de Estudo às cargas mecânicas de trabalho, segundo a unidade de trabalho, atividades realizadas e desgastes desencadeados por esta exposição. HUdE 2006.

\begin{tabular}{|c|c|c|c|}
\hline Tipos de cargas & Unidades expostas & Atividades expostas & Desgastes gerados \\
\hline \multicolumn{4}{|l|}{ Cargas Mecânicas } \\
\hline $\begin{array}{l}\text { Manipulação de } \\
\text { materiais } \\
\text { pontiagudos e } \\
\text { cortantes }\end{array}$ & $\begin{array}{l}\text { PSI } \\
\text { Urodinâmica } \\
\text { Cirurgia Pediátrica } \\
\text { CTI } \\
\text { UTI Neonatal } \\
\text { Quimioterapia Ambulatorial } \\
\text { Pediatria } \\
\text { Clínica Médica }\end{array}$ & $\begin{array}{l}\text { Assistência; colheita de sangue; punção venosa; } \\
\text { lavagem de bandejas de procedimentos; seringas; } \\
\text { exame de glicemia capilar; curativos; preparo de } \\
\text { medicamentos; aspirar solventes com seringa } \\
\text { hipodérmica e durante a administração no paciente; } \\
\text { utilização de agulhas e cateteres venosos durante } \\
\text { procedimentos e coleta de exames; limpeza; punção } \\
\text { de subclávia; traqueostomia; administração de } \\
\text { medicação. }\end{array}$ & $\begin{array}{l}\text { Furando o dedo com } \\
\text { tesouras, agulhas e bisturi; } \\
\text { tensão; medo de adquirir } \\
\text { doenças; possibilidade de } \\
\text { infecção com material } \\
\text { contaminado com fluidos } \\
\text { corpóreos; doenças como } \\
\text { VDRL, HIV, hepatite. }\end{array}$ \\
\hline Quedas & $\begin{array}{l}\text { Cirurgia Pediátrica } \\
\text { Divisão de Enfermagem } \\
\text { Clínica Médica }\end{array}$ & $\begin{array}{l}\text { Atividade de emergência em PSI; chão encerado em } \\
\text { todo hospital; presença de escada e piso } \\
\text { escorregadio; piso deslizante; transporte de } \\
\text { pacientes ou outras atividades através de escada; } \\
\text { quando há elevadores com defeito ou falta de } \\
\text { eletricidade.; }\end{array}$ & $\begin{array}{l}\text { Queda; "já escorreguei mas } \\
\text { não me machuquei"; } \\
\text { traumas fraturas; seqüelas. }\end{array}$ \\
\hline $\begin{array}{l}\text { Preensão de } \\
\text { partes do corpo }\end{array}$ & $\begin{array}{l}\text { PSI } \\
\text { Urodinâmica } \\
\text { Cirurgia Pediátrica }\end{array}$ & $\begin{array}{l}\text { Recebimento de paciente no C.C.; mudança das } \\
\text { camas e berços entre as enfermarias; nos leitos; } \\
\text { móveis com quina; transporte dos pacientes. }\end{array}$ & $\begin{array}{l}\text { Acantoplastia; preensão dos } \\
\text { dedos entre a cama e a } \\
\text { porta da enfermaria; } \\
\text { hematomas. }\end{array}$ \\
\hline
\end{tabular}


Quadro IX - Caracterização da exposição dos trabalhadores de enfermagem do Hospital Universitário de Estudo às cargas mecânicas de trabalho, segundo a unidade de trabalho, atividades realizadas e desgastes desencadeados por esta

exposição. HUdE, 2006. (continuação)

\begin{tabular}{|c|c|c|c|}
\hline Tipos de cargas & Unidades expostas & Atividades expostas & Desgastes gerados \\
\hline \multicolumn{4}{|l|}{ Cargas Mecânicas } \\
\hline Agressão física & $\begin{array}{l}\text { Cirurgia Pediátrica } \\
\text { CTI } \\
\text { Medicina do Trabalho } \\
\text { Quimioterapia Ambulatorial } \\
\text { Divisão de Enfermagem }\end{array}$ & $\begin{array}{l}\text { Acompanhantes dos pacientes no horário de } \\
\text { visitas; atendimento a pacientes psiquiátricos; } \\
\text { assistência a pacientes desorientados; agressão } \\
\text { de índios por ciúmes; por receber todos que nos } \\
\text { procuram, somos mais expostos a comunidade do } \\
\text { hospital e a população, crianças e mães durante } \\
\text { procedimentos e discussões. }\end{array}$ & $\begin{array}{l}\text { Lesão corporal; temor } \\
\text { da equipe ao prestar } \\
\text { assistência; estresse; } \\
\text { furtos na instituição. }\end{array}$ \\
\hline Outros acidentes & $\begin{array}{l}\text { Quimioterapia Ambulatorial } \\
\text { Divisão de Enfermagem }\end{array}$ & $\begin{array}{l}\text { Derrame de drogas anti-neoplásicas dentro do } \\
\text { hospital, devido a estrutura física antiga e } \\
\text { desgastada. }\end{array}$ & $\begin{array}{l}\text { Alergia; dispnéia; } \\
\text { urticária. }\end{array}$ \\
\hline
\end{tabular}


Em relação às cargas mecânicas, os trabalhadores apontaram o manuseio de materiais pontiagudos e cortantes, quando da administração de medicamentos e realização de procedimentos diversos, como causadores de perfurações e cortes. Além disto, esta interação com a carga mecânica, é potencializada pela biológica nos acidentes originados por materiais perfurocortantes. Isto porque o material é, de fato ou potencialmente, contaminado, o que é gerador de medo e tensão de adquirir doenças demonstrando, então, a potencialização pela carga psíquica, conforme visualizado nos desgastes gerados do quadro acima.

As quedas, referidas como sendo devidas à presença de piso molhado ou escorregadio ou pela utilização da escada, devido há falta de eletricidade, foram cargas mecânicas que, também, apareceram relacionadas às cargas físicas. Isso demonstra que a interação das cargas potencializa os riscos de acidentes e o desgaste psíquico. O transporte dos pacientes e o manuseio de equipamentos, em más condições de conservação, foram apontados como responsáveis pelas preensões e choque mecânico, com conseqüente aparecimento de hematomas.

A agressão física aparece associada às relações estabelecidas com os pacientes, especialmente da área psiquiátrica, assim como pelo convívio com os familiares e acompanhantes dos pacientes em geral. A realidade do HUdE apresenta uma especificidade bastante interessante, por atender a demanda indígena das proximidades. Lida constantemente com conflitos de crenças e paradigmas, o que reflete em agressões por parte dos familiares. Esta agressão física é potencializada pelo desgaste psicológico, além das 
lesões corporais nos trabalhadores. Os participantes também relataram os furtos na instituição, como sendo uma agressão física ao patrimônio.

Silva (1996) menciona que a exposição dos trabalhadores às cargas mecânicas ocorre em simultaneidade às cargas psíquicas, pois no entender dos trabalhadores de enfermagem, o ritmo acelerado de trabalho, a repetitividade das tarefas e a pressão para a realização do trabalho, potencializam a exposição às cargas mecânicas, podendo implicar na ocorrência de acidentes de trabalho.

Caixeta e Branco (2005), Canini, Gir, Hayashida, Machado (2002), Sarquis (1999), Silva (1996) evidenciaram que os acidentes com materiais perfuro-cortantes são a principal carga mecânica referida e pelos trabalhadores de enfermagem, dado igualmente encontrado no HUdE nos anos de 2004 e 2005, notificados junto ao SESMT como acidentes de trabalho.

Em seu estudo com trabalhadores de enfermagem, Cruz (2006) refere, que a agressão física é uma situação potencializadora do estresse no trabalho, semelhantemente ao apontado pelos trabalhadores do HUdE.

\subsubsection{Cargas fisiológicas}

As cargas fisiológicas estão associadas à manipulação excessiva de pesos, posições inadequadas e incômodas e trabalho noturno e rodízio em turnos (Silva, 1996), como podem ser visualizadas a seguir. 
Quadro X - Caracterização da exposição dos trabalhadores de enfermagem do Hospital Universitário de Estudo às cargas fisiológicas de trabalho, segundo a unidade de trabalho, atividades realizadas e desgastes desencadeados por esta exposição. HUdE, 2006.

\begin{tabular}{|c|c|c|c|}
\hline Tipos de cargas & Unidades expostas & Atividades expostas & Desgastes gerados \\
\hline \multicolumn{4}{|l|}{$\begin{array}{l}\text { Cargas } \\
\text { Fisiológicas }\end{array}$} \\
\hline $\begin{array}{l}\text { Manipulação de } \\
\text { pesos }\end{array}$ & $\begin{array}{l}\text { PSI } \\
\text { Urodinâmica } \\
\text { Cirurgia Pediátrica } \\
\text { CTI } \\
\text { UTI Neonatal } \\
\text { Medicina do Trabalho } \\
\text { Quimioterapia Ambulatorial }\end{array}$ & $\begin{array}{l}\text { Manipulação de paciente com lesão medular; } \\
\text { empurrar macas, berços e mesas; manipulação de } \\
\text { pacientes obesos e de difícil locomoção; mudança } \\
\text { de leitos; limpeza das bombas das fototerapias e } \\
\text { balão de oxigênio; transporte, transferências e } \\
\text { mudanças de decúbito de pacientes; ajuda na } \\
\text { deambulação de paciente; levantar crianças do chão } \\
\text { para a maca; banho no leito. }\end{array}$ & $\begin{array}{l}\text { Dores nas costas, braços } \\
\text { e pernas; dores } \\
\text { musculares; LER; } \\
\text { lombalgia; problemas } \\
\text { ósteo-musculares; } \\
\text { torções. }\end{array}$ \\
\hline Trabalho em pé & $\begin{array}{l}\text { PSI } \\
\text { Urodinâmica } \\
\text { Cirurgia Pediátrica } \\
\text { CTI } \\
\text { UTI Neonatal } \\
\text { Quimioterapia } \\
\text { Ambulatorial } \\
\text { Divisão de Enfermagem } \\
\text { Pediatria }\end{array}$ & $\begin{array}{l}\text { Assistência ao paciente; ministração de aulas; } \\
\text { punção venosa; colhendo sangue; no alojamento } \\
\text { conjunto e BAR;encaminhamento de } \\
\text { material;durante todo o dia, andar por todo o } \\
\text { hospital; no dia a dia, ao lidar com grande número de } \\
\text { pacientes ou paciente grave; andar muito para } \\
\text { marcar exame; resolver problemas dos pacientes e } \\
\text { da clínica; na maioria dos procedimentos. }\end{array}$ & $\begin{array}{l}\text { Dor em MMII; cansaço } \\
\text { excessivo; desgaste } \\
\text { físico; calos nos pés; } \\
\text { exposição solar; varizes. }\end{array}$ \\
\hline $\begin{array}{l}\text { Percurso de } \\
\text { longas distâncias }\end{array}$ & $\begin{array}{l}\text { PSI } \\
\text { Urodinâmica } \\
\text { Cirurgia Pediátrica } \\
\text { UTI Neonatal } \\
\text { Pediatria }\end{array}$ & $\begin{array}{l}\text { Supervisão; assistência nas salas cirúrgicas; } \\
\text { buscando medicação; levando pacientes para } \\
\text { realizar exames; alojamento conjunto; no dia a dia, } \\
\text { ao lidar com grande número de pacientes ou } \\
\text { paciente grave; resolver problemas em outros } \\
\text { hospitais; transporte de pacientes. }\end{array}$ & $\begin{array}{l}\text { Cansaço; estresse; dor } \\
\text { nas pernas; cansaço } \\
\text { físico; acidentes. }\end{array}$ \\
\hline
\end{tabular}


Quadro X - Caracterização da exposição dos trabalhadores de enfermagem do Hospital Universitário de Estudo às cargas fisiológicas de trabalho, segundo a unidade de trabalho, atividades realizadas e desgastes desencadeados por esta

exposição. HUdE, 2006. (continuação)

\begin{tabular}{|c|c|c|c|}
\hline Tipos de cargas & Unidades expostas & Atividades expostas & Desgastes gerados \\
\hline \multicolumn{4}{|l|}{$\begin{array}{l}\text { Cargas } \\
\text { Fisiológicas }\end{array}$} \\
\hline $\begin{array}{l}\text { Posições } \\
\text { inadequadas e } \\
\text { incômodas }\end{array}$ & $\begin{array}{l}\text { PSI } \\
\text { Urodinâmica } \\
\text { Cirurgia Pediátrica } \\
\text { UTI Neonatal } \\
\text { Quimioterapia Ambulatorial } \\
\text { Pediatria }\end{array}$ & $\begin{array}{l}\text { Na realização de cateterismo vesical; troca de } \\
\text { selo d'água, de dreno de tórax; colher diurese } \\
\text { de SVD; na assistência ao RN, como segurá-lo } \\
\text { para uma dissecção; RX; cateterismo } \\
\text { umbilical; durante punções venosas; ao sentar } \\
\text { para fazer o relatório em uma cadeira } \\
\text { quebrada; coleta de urina. }\end{array}$ & $\begin{array}{l}\text { Lombalgia; dor nas costas e } \\
\text { pernas; problemas na coluna; } \\
\text { dores musculares; dores no } \\
\text { corpo; "adquiri uma } \\
\text { anteversão dos dois últimos } \\
\text { segmentos do cóccix"; } \\
\text { torções; dores. }\end{array}$ \\
\hline Trabalho noturno & $\begin{array}{l}\text { Cirurgia Pediátrica } \\
\text { Divisão de Enfermagem } \\
\text { Pediatria }\end{array}$ & $\begin{array}{l}\text { Falta de auxiliar; } 2^{0} \text { turno em casa; cuidando } \\
\text { das crianças e da família; plantão noturno. }\end{array}$ & $\begin{array}{l}\text { Sono; cansaço; desgaste } \\
\text { físico e emocional; } \\
\text { dificuldade para dormir; } \\
\text { desgaste imunológico; vida } \\
\text { social comprometida; } \\
\text { propensão a diabetes e } \\
\text { hipertensão; falta de } \\
\text { memória; insônia. }\end{array}$ \\
\hline $\begin{array}{l}\text { Rodízio de turno e } \\
\text { horas extras }\end{array}$ & $\begin{array}{l}\text { Cirurgia Pediátrica } \\
\text { UTI Neonatal } \\
\text { Pediatria }\end{array}$ & É próprio da profissão & Ninguém referiu desgaste. \\
\hline
\end{tabular}


As cargas fisiológicas aparecem com bastante destaque nas falas dos participantes, devido à prevalência dos sintomas e desgaste gerados pela exposição. A manipulação de pacientes com peso elevado e do equipamento para a transferência destes nos locais, deambulação, realização de banho e outros procedimentos, foi apontada como um dos fatores responsáveis pelas dores ósteo-músculo-articulares, Lesão por Esforço Repetitivo (LER) e Doença Ocupacional Relacionada ao Trabalho (DORT). O trabalhador de enfermagem, além de realizar suas atividades predominantemente em pé, adota posições inadequadas e incômodas para a execução de determinadas tarefas, para as quais não são disponibilizados equipamentos auxiliares, que minimizariam os efeitos sobre a posição. Somado a estes fatores, o percurso de longas distâncias entre os setores do hospital, gera cansaço, estresse e aparecimento de varizes.

O trabalho noturno aparece nas falas como um segundo turno de trabalho, uma vez que, devido à enfermagem se caracterizar por um trabalho essencialmente feminino, o primeiro turno refere-se ao domiciliar e ao cuidado como os filhos. Outro fator que agrava o trabalho noturno é o fato de o hospital dispor de poucos profissionais, o que desencadeia a sobrecarga de trabalho para aqueles profissionais. Em relação ao rodízio de turnos e realização de horas extras, os trabalhadores referiram como sendo uma característica própria da profissão e, por isso, não referiram desgaste decorrente desta carga. 
Nas falas captadas com o grupo focal emergiram algumas especificidades diagnosticadas pelos trabalhadores, que as apresentaram com certo incômodo.

“... os técnicos e auxiliares, muitas vezes eles tem que fazer um trabalho físico mesmo tem que levanta o paciente de 120 kilos que nós temos lá, então eles são, às vezes, 90\% são mulheres, então são submetidos a isso a um tempo muito grande..." (Giacomo Puccini)

“... a diretoria diminuiu a quantidade de leitos, mas também reduziu muito a quantidade de funcionários, mas muito mesmo, só que diminuíram o número de leitos mas não diminuíram o número de internação..." (Rossini)

Os dados acima demonstram o reconhecimento do enfermeiro, frente à acentuada exposição às cargas de trabalho, pelos técnicos e auxiliares de enfermagem que, por assumirem a assistência junto ao paciente, sofrem o impacto direto desta interação. Além disso, apontam para a desestrutura organizacional, que reduz o número de leitos e funcionários, mesmo não havendo redimensionamento do número de atendimentos. Ou seja, a manutenção da demanda com a redução da estrutura física e humana sobrecarregam os trabalhadores que, além da duplicação das tarefas, devem dar conta do rearranjo estrutural para não comprometer a vida dos pacientes.

Os resultados da pesquisa realizada por Gurgueira, Alexandre, Correa Filho (2003), em pesquisa sobre a prevalência de fatores músculoesqueléticos nos trabalhadores de enfermagem, encontraram o relato de 93\% da população pesquisada em relação a algum tipo de sintoma osteomusculares em múltiplas regiões corporais, atingindo principalmente a região lombar, ombros, joelhos e região cervical. A dor lombar continua 
sendo o fator principal de absenteísmo e os procedimentos relacionados com a movimentação e transporte de pacientes são considerados os principais causadores de dor na região lombar.

Murofuse e Marziale (2005) referem, no estudo, que os trabalhadores de enfermagem manifestaram lesões que afetaram as mãos, braços, pescoço, coluna e joelhos, agrupadas nos grupos das LER-DORT. Alexandre (1998) destaca que as unidades hospitalares têm problemas ergonômicos comuns específicos, uma possível justificativa para o aparecimentos das DORTs. Nishide e Benatti (2004) consideram que os trabalhadores de enfermagem desenvolvem muitas atividades que exigem esforço físico, não somente no manuseio do paciente, mas também uma grande extensão de outros trabalhos como retirar e colocar monitores de prateleiras e mesas auxiliares, organizar os equipamentos e mobiliário à beira do leito e em salas especiais, entre outros.

\subsubsection{Cargas psíquicas}

As cargas psíquicas estão relacionadas à atenção constante, supervisão estrita, ritmo acelerado de trabalho, trabalho parcelado, monótono e repetitivo, falta de defesas coletivas, agressão psíquica, insatisfação, fadiga, tensão, estresse, consumo de álcool e drogas (Silva, 1996). 
Quadro XI - Caracterização da exposição dos trabalhadores de enfermagem do Hospital Universitário de Estudo às cargas psíquicas de trabalho, segundo a unidade de trabalho, atividades realizadas e desgastes desencadeados por esta exposição. HUdE, 2006.

\begin{tabular}{|c|c|c|c|}
\hline Tipos de cargas & Unidades expostas & Atividades expostas & Desgastes gerados \\
\hline \multicolumn{4}{|l|}{ Cargas Psíquicas } \\
\hline Agressão psíquica & $\begin{array}{l}\text { Cirurgia Pediátrica } \\
\text { Medicina do Trabalho } \\
\text { Quimioterapia Ambulatorial } \\
\text { Pediatria }\end{array}$ & $\begin{array}{l}\text { No ambulatório; consultas de enfermagem; cobranças } \\
\text { de exames de acidentes de trabalho extraviados pelo } \\
\text { laboratório e demora na emissão dos resultados; } \\
\text { agressão de pacientes e acompanhantes desorientados } \\
\text { (psiquiátricos); ouvir grosserias e agressões verbais } \\
\text { desnecessárias. }\end{array}$ & $\begin{array}{l}\text { Chateação; revolta; } \\
\text { desestímulo; estresse; } \\
\text { irritabilidade; tensão no } \\
\text { trabalho; } \\
\text { desmotivação; tristeza. }\end{array}$ \\
\hline Trabalho feminino & $\begin{array}{l}\text { Cirurgia Pediátrica } \\
\text { Pediatria } \\
\text { Quimioterapia Ambulatorial }\end{array}$ & $\begin{array}{l}\text { Orientando as mães; na assistência de enfermagem; no } \\
\text { trabalho doméstico; "no período que não trabalho estou } \\
\text { cuidando dos afazeres domésticos". }\end{array}$ & $\begin{array}{l}\text { Desgaste do } \\
\text { trabalhador }\end{array}$ \\
\hline $\begin{array}{l}\text { Falta de defesas } \\
\text { coletivas }\end{array}$ & $\begin{array}{l}\text { PSI } \\
\text { Urodinâmica } \\
\text { Cirurgia Pediátrica } \\
\text { Quimioterapia Ambulatorial } \\
\text { Divisão de Enfermagem }\end{array}$ & $\begin{array}{l}\text { C.C; falta de atuação das instituições e sindicatos; } \\
\text { "durante as reuniôes temos mais médicos do que outros } \\
\text { profissionais"; "devido a hegemonia médica somos } \\
\text { submetidos a tratamento ríspidos e insegurança" }\end{array}$ & $\begin{array}{l}\text { chefia ausente em } \\
\text { todos os aspectos; } \\
\text { estresse; cansaço; } \\
\text { desgaste físico; } \\
\text { insegurança; } \\
\text { preocupação; tensão; } \\
\text { nervosismo. }\end{array}$ \\
\hline $\begin{array}{l}\text { Abuso de álcool e } \\
\text { drogas }\end{array}$ & Cirurgia Pediátrica & Atendimento ao paciente alcoolizado & Discussão; irritação. \\
\hline $\begin{array}{l}\text { Supervisão estrita } \\
\text { da chefia e outros } \\
\text { profissionais }\end{array}$ & $\begin{array}{l}\text { Cirurgia Pediátrica } \\
\text { Quimioterapia Ambulatorial } \\
\text { Divisão de Enfermagem } \\
\text { Pediatria }\end{array}$ & $\begin{array}{l}\text { Comprimento de horário todos os dias no hospital; em } \\
\text { todas as atividades, durante o horário de trabalho. }\end{array}$ & $\begin{array}{l}\text { Insatisfação no } \\
\text { trabalho; desgaste } \\
\text { físico e emocional }\end{array}$ \\
\hline
\end{tabular}


Quadro XI - Caracterização da exposição dos trabalhadores de enfermagem do Hospital Universitário de Estudo às cargas psíquicas de trabalho, segundo a unidade de trabalho, atividades realizadas e desgastes desencadeados por esta exposição. HUdE, 2006. (continuação)

\begin{tabular}{|c|c|c|c|}
\hline Tipos de cargas & Unidades expostas & Atividades expostas & Desgastes gerados \\
\hline \multicolumn{4}{|l|}{ Cargas Psíquicas } \\
\hline $\begin{array}{l}\text { Falta de } \\
\text { criatividade e } \\
\text { autonomia }\end{array}$ & $\begin{array}{l}\text { PSI } \\
\text { Urodinâmica } \\
\text { Quimioterapia Ambulatorial } \\
\text { Divisão de Enfermagem } \\
\end{array}$ & $\begin{array}{l}\text { Assistência no PSI e no CC; em atividades de destaque } \\
\text { da enfermagem; "as vezes falta de autonomia" }\end{array}$ & $\begin{array}{l}\text { Frustrações; } \\
\text { desanimo. }\end{array}$ \\
\hline Atenção constante & $\begin{array}{l}\text { Cirurgia Pediátrica } \\
\text { CTI } \\
\text { UTI Neonatal } \\
\text { Quimioterapia Ambulatorial } \\
\text { Divisão de Enfermagem } \\
\text { Pediatria }\end{array}$ & $\begin{array}{l}\text { Na assistência ao RN; durante toda a administração de } \\
\text { quimioterápicos; todos os dias, durante todo período de } \\
\text { trabalho; "no trabalho que lidamos com vida é preciso } \\
\text { atenção constante, porque um erro é fatal"; } \\
\text { monitorização do paciente. }\end{array}$ & Estresse. \\
\hline $\begin{array}{l}\text { Falta de } \\
\text { comunicação }\end{array}$ & $\begin{array}{l}\text { Quimioterapia Ambulatorial } \\
\text { Divisão de Enfermagem }\end{array}$ & $\begin{array}{l}\text { Durante prestação da assistência; com algumas } \\
\text { diretorias. }\end{array}$ & $\begin{array}{l}\text { Desgaste emocional; } \\
\text { desgaste da equipe. }\end{array}$ \\
\hline $\begin{array}{l}\text { Ritmo acelerado } \\
\text { de trabalho }\end{array}$ & $\begin{array}{l}\text { Urodinâmica } \\
\text { Cirurgia Pediátrica } \\
\text { Medicina do Trabalho } \\
\text { Pediatria } \\
\text { Quimioterapia Ambulatorial } \\
\text { Divisão de Enfermagem }\end{array}$ & $\begin{array}{l}\text { PSI; Urodinâmica; Educação Continuada; preparar } \\
\text { medicação e puncionar veia de criança para realizar } \\
\text { cirurgia e exames TC; consultas de enfermagem com } \\
\text { vários atendimentos e apenas } 2 \text { profissionais; durante } \\
\text { todo o período, todos os dias, a falta de funcionários } \\
\text { sobrecarrega; rotina da manhã; situações de } \\
\text { emergências; } \\
\text { medicamentos+banho+prescrição+exames. }\end{array}$ & $\begin{array}{l}\text { Tensão quando não } \\
\text { consegue puncionar } \\
\text { por ser muito difícil; } \\
\text { cansaço físico e } \\
\text { mental; estresse; } \\
\text { cansaço excessivo da } \\
\text { equipe. }\end{array}$ \\
\hline $\begin{array}{l}\text { Trabalho repetitivo } \\
\text { e monótono }\end{array}$ & $\begin{array}{l}\text { UTI Neonatal } \\
\text { Pediatria }\end{array}$ & $\begin{array}{l}\text { Banho (alojamento conjunto); verificação de } \\
\text { temperatura; manipulação do RN; aferição de sinais. }\end{array}$ & $\begin{array}{l}\text { Insatisfação; síndrome } \\
\text { do túnel de carpo; } \\
\text { estresse. }\end{array}$ \\
\hline
\end{tabular}


As cargas psíquicas obtiveram maior destaque nas falas dos participantes, uma vez que estão, muitas vezes associadas a todas as outras cargas, presentes nos processos de trabalho. Assim, durante a discussão das demais cargas, o desgaste psíquico foi apontado pelos trabalhadores. Portanto, as cargas psíquicas aparecem em todas as atividades realizadas pela enfermagem, seja na relação com o objeto, meio e instrumento de trabalho, seja na própria interação com a organização ou na interface institucional.

As falas obtidas nos grupos focais permitem a apreensão das percepções dos trabalhadores de enfermagem em relação a este determinante.

“...tem o estresse psicológico de todo o dia de muitas doenças, você vê uma pessoa lá de 70 anos e você fala: pô, mas parece tanto com o meu avô e isso vai mexendo com os profissionais... (...) eu acho esses estresse, o estresse psicológico a que a equipe está submetida talvez mais perigoso que o estresse físico..." (Giacomo Puccini)

“.. a enfermagem trabalha muito com a frustração porque todos nós trabalhamos sempre buscando fazer o melhor a gente esbarra sempre em alguma coisa, como ali: falta de autonomia..." (Giacomo Puccini)

"... ela (refere-se à sua chefia) não deixou eu cuidar mais dele mais porque eu entrei numa depressão (...) quando a infectologista chamou a mãe e falou que o resultado era positivo, então assim, deu um turbo na minha cabeça, como se fosse meu filho, entendeu? Então daí eu saí da da enfermaria chorando... (...) Daí eu fui comentar com ela (chefe): mas é tão duro, tal, tal, tal, é um sentimento tão horrível, eu chorei o dia todo e ela me chamando, brigou comigo pra mim acordar, né, porque eu não podia ficar daquele jeito, tal (...) quando eu fui pra casa a noite, cheguei meia-noite chorando, aí eu chorei a vontade né (...) tem pacientes que você se prende mais, você sofre mais pela situação (Orlando Gibbons)

"São inúmeras as cargas psíquicas tem dia de eu sair daí e num conseguir nem dirigir..." (Erik Satie)

"...e eu fiquei desesperado (refere-se à demora do exame de HIV após acidente com perfuro-cortante) (...) foi uma semana sem dormi, porque demorou pra sair o resultado, uma sensação de desgaste horrível..." (Erik Satie) 
“... o doutor fulano gritava (...) tinha uns que sapateavam! ... porque se eu fosse ficar, eu ia ter uma crise hipertensiva, eu ia parar no pra emergência e ia ficar desagradável, aí cada um absorve de maneira diferente... (Erik Satie)

"... aí chega (refere-se aos residentes) assim na frente dos pais $e$ falam: olha, vocês tem que exigir! Então algumas mães elas ficam do nosso lado porque elas sabem que a gente tem mais experiência Então assim, o nosso lá maior desgaste psíquico é esse!" (Amadeus Mozart)

"... acho que foi uma vez que o residente sentou comigo, vamos sentar pra conversar com a mãe pra gente falar o diagnóstico, ver como a gente vai dar, foi uma vez só e nessa uma vez acabou que quem mais falou fui eu porque quando ele falava as coisas assim, tudo muito técnico, até a própria mãe não entendia ..." (Amadeus Mozart)

“... é uma carga muito pesada, há uma diferença da UTI adulto pra UTI neo, porque ela é muito pesada, é muito estressante mesmo, a mãe está ali 24 horas e o médico também está ali 24 horas, ele não vai pra casa e a mãe não vem perguntar pra gente..." (Rossini)

“... daí tinha uma mesa e eu fiquei lá em baixo escondida, mas eu fiquei tanto tempo escondida debaixo da mesa e o cirurgião me procurando... eu precisava daquele tempo pra me desestressar..." (Mendelsonn)

“... carga psíquica também pela insatisfação salarial e porque não é reconhecido..." (Edward WIgar)

Deste modo, a agressão psíquica aparece, especialmente, nas relações estabelecidas com pacientes e demais membros da equipe de saúde que, por motivos diversos, adotam uma postura agressiva e ofensiva frente aos trabalhadores de enfermagem. Como conseqüência, tem-se a manifestação de desestímulo, estresse, irritabilidade e tensão dos trabalhadores.

O trabalho feminino constitui, isoladamente, um fator de desgaste. Isto porque, a mulher possui uma dupla jornada de trabalho, sendo ela a responsável pelas atividades domésticas e educacionais junto aos filhos. A enfermagem, 
predominantemente feminina, apresenta acentuadamente este desgaste pela sobrecarga de trabalho, que se expressa no corpo físico das trabalhadoras.

A falta de defesas coletivas foi apresentada pela desarticulação existente entre os trabalhadores frente à Instituição, especialmente pela ausência de uma gerência pró-ativa e com capacidade de liderança. Esta situação fragiliza os trabalhadores frente à articulação das demais categorias profissionais e à própria organização, gerando insegurança, tensão e nervosismo.

O abuso de álcool e drogas não foi referido pelos sujeitos do grupo focal. Foi feita referência em relação ao atendimento de pacientes alcoolizados como geradora de irritação.

O relacionamento com a chefia ocorre de forma restrita, no que se refere ao cumprimento de horários e atividades. Não foram referidos pelos sujeitos a postura autoritária ou repressora adotada pelas chefias. O desgaste físico e emocional desencadeado por esta relação se deve pela limitação de turnos e horários de trabalho. Somado a isso, a falta de comunicação, tanto dentro da equipe quanto em relação às demais diretorias do hospital, foram citadas como determinantes no desgaste emocional da equipe.

A falta de autonomia e criatividade foi referida como geradoras de frustrações pelos trabalhadores, uma vez que há o cerceamento de decisões em determinadas esferas de poder. Entretanto, estas falas não apareceram com expressividade. 
A atenção constante, o ritmo acelerado e o trabalho repetitivo e monótono, decorrentes da complexidade das ações que são realizadas, do reduzido quadro de profissionais frente a demanda da população e do próprio parcelamento das tarefas também foram fatores relacionados à geração de estresse e cansaço físico e mental, além de manifestações físicas e doenças, como LER.

Os encontros do grupo focal permitiram a apreensão dos sentimentos e percepções dos trabalhadores, quanto ao desgaste psíquico, originado pelas diversas situações de trabalho. É importante observar que a identificação do profissional com o trabalho fazem emergir sensações exacerbadas de empatia, fazendo com que este sujeito se envolva a tal ponto com a realidade apresentada, passando a sofrer juntamente com o paciente. Isto acontece porque não há como desvincular o trabalho da vida pessoal e as circunstâncias que, de alguma forma, se assemelham às situações vivenciadas por este trabalhador. Estas fazem emergir a identificação e, por vezes, o reviver da situação. Em alguns casos, este processo adquire tamanha proporção que o trabalhador tem que ser afastado de seu trabalho ou transferido para outra unidade, especialmente, quando ocorre o óbito do paciente.

Outra situação bastante relevante é a ansiedade decorrente de resultados de exames, quando de acidentes de trabalho com materiais (potencialmente) contaminados. Este ínterim entre a coleta do material e o resultado foi apontado como gerador de estresse e insônia. 
As relações que são estabelecidas com a equipe médica, pela própria hegemonia histórica desta profissão, foram referidas como extremamente desgastantes. Especialmente devido à postura que este profissional adota frente ao paciente e familiares, geralmente colocando a enfermagem em cheque. Isto ocorre devido à resistência médica em ser contrariada pela enfermagem, que busca 'ganhar' os clientes invalidando as orientações de enfermagem (quando estas questionam alguma conduta tomada). A própria falha na comunicação verbal entre as duas categorias profissionais é um forte fator de desgaste psíquico, uma vez que, em unidade como de centro cirúrgico, é bastante comum o médico gritar para fazer cumprir suas exigências - situação que, além de constrangedora, emerge sentimentos de subalternidade, insatisfação, desmotivação e revolta.

Um outro fator referido foi a sobrecarga advinda da comunicação de morte junto aos familiares. O trabalhador refere que, na maioria das vezes, esta atribuição acaba sendo, direta ou indiretamente, passada para a enfermagem. Isto porque o médico ou explicitamente solicita que a enfermagem faça a comunicação do óbito, ou passa a informação em termos técnicos, geralmente incompreensíveis aos familiares. Assim, fica sob a responsabilidade da enfermagem lidar com uma situação extremamente conflitante, além de fornecer apoio psicoemocional aos familiares.

A insatisfação salarial também foi apontada como um importante fator de desgaste psíquico, uma vez que ela decorre da não valorização profissional, além 
de não subsidiar as necessidades demandadas, desencadeando a busca de mais outra atividade remunerada para aumentar a renda.

Em linhas gerais, o desgaste psíquico é percebido como intrínseco ao trabalho de enfermagem, ainda que todas os processos destrutivos do trabalho são neutralizados. Isto se deve ao fato do profissional lidar com o risco eminente de morte de seu objeto de trabalho, o que gera uma obrigatoriedade inconsciente de dedicação total para a manutenção da vida e recuperação da saúde. Muitas vezes, quando isto não é alcançado, aparece a sensação de impotência e frustração, como se a culpa recaísse sobre o trabalhador, ainda que, este saiba que não a possui.

Laurell e Noriega (1989: 112) apontam que "as cargas psíquicas, finalmente, têm o mesmo caráter que as fisiológicas à medida que adquirem materialidade através da corporeidade humana". Entretanto, quando estas cargas não são somatizadas ocorre conforme Silva (1996) refere, no qual as doenças são dificilmente reconhecidas como provocadas pelo trabalho em oposição aos acidentes, que são facilmente detectados, pois se expressam, geralmente, pela forma muito visível de uma lesão".

Leitão (2002) refere que o estresse e desgaste do funcionário decorrem da carga horária, multiplicidade de ações relativas ao cuidado, vínculos com outros empregos, falta de reconhecimento institucional, baixa remuneração e cargas emocionais. Nessa perspectiva, administrar as dificuldades presentes no cotidiano 
de trabalho faz com que as participantes vivenciem sentimentos como sofrimento, frustração e desgaste físico e psíquico.

Gelbcke (1991) resgata que os trabalhadores de enfermagem estão submetidos aos baixos salários, o que implica em dificuldade de acesso a bens e serviços, repercutindo no seu processo saúde-doença, provocando desgaste físico e psíquico.

Novamente a tônica é dada ao relacionamento que é estabelecido com a instituição de trabalho. Recuperando a contextualização realizada quando da construção do objeto de estudo, temos que o enfermeiro, no exercício do gerenciamento, ocupa importante papel articulador entre as forças de trabalho e a entidade empregadora. Assim, se este profissional isenta-se de suas responsabilidades na interface da comunicação, fortalece o padrão de alienação sofrido pelo trabalhador de enfermagem.

Batista e Bianchi (2006) consideram que a estrutura organizacional da instituição hospitalar tem sua parcela na ocorrência de estresse para o enfermeiro, o que interfere diretamente em suas condições de vida. Esta afirmação reforça a importância da enfermagem gerencial na mediação das necessidades, de forma a desenvolver ações que promovam a QVT.

Silva (1996) refere que os danos podem expressar-se em momentos diferentes, imediatamente após a exposição do trabalhador às cargas, como ocorre nas lesões causadas pelos acidentes de trabalho ou após um período de tempo variável, como ocorre com morbidades específicas, como infecções, 
hérnias e estresse. As morbidades não visíveis nem sempre são consideradas como sendo decorrentes do trabalho, o que talvez justifique a postura passiva acerca dos problemas de saúde dos trabalhadores, uma vez que algo que é sentido e não manifestado, não necessariamente é considerado.

Assim, o trabalhador de enfermagem continua exposto às diversas cargas de trabalho e sofre os desgastes decorrentes delas, ainda que a impere o desconhecimento em relação a estes fatos.

\subsection{Busca de proposições para intervenção na realidade}

A proposição de ações voltadas para a intervenção na realidade apresentada contrapôs-se com o processo de trabalho, não obstante um processo de desgaste sofrido pelos enfermeiros que assumem a função gerencial. Como já referido, o intervalo entre o primeiro e último momento de captação dos dados foi marcado por uma profunda mudança junto a Divisão de Enfermagem do hospital universitário.

No primeiro momento, a chefia da Divisão era exercida por John S. Bach, que participou dos três encontros do grupo focal. No último momento, quando da devolutiva dos dados para o cenário e captação das propostas de promoção da qualidade de vida, a gerência do serviço havia sido assumida por Alexander Scriabin. Esta troca seria esperada quando da mudança geral das diretorias do 
hospital, entretanto, ela ocorreu após, aproximadamente, oito meses que John S. Bach havia assumido o cargo. Segundo apresentado pelos sujeitos do último encontro do grupo focal, esta transição ocorreu por uma mobilização de alguns trabalhadores que discordavam do modo gerencial adotado pelo profissional. Se por um lado, isto demonstra que a organização de defesas coletivas não está tão desarticulada, por outro lado esvaziou o momento da discussão das proposições.

O fato de ter ocorrido uma quebra nos modos operandis do processo de trabalho, já que uma enfermeira possuía um perfil e uma política de ações diferente da outra, implicou no comprometimento de continuidade do processo reflexivo que havia sido iniciado há meses atrás. Evidenciou-se que a mudança de chefia havia afetado a todos, pois, na dinâmica para interação do grupo, duas duplas referiram o episódio (sendo as duplas onde estava a antecessora e a atual chefia da divisão), demonstrando a emergência da discussão deste tema.

Aparentemente, não houve conflito entre as duas enfermeiras, pois ambas referiram estar satisfeitas com o encaminhamento das decisões. Entretanto, conforme considera Minayo (1994) utilizando-se dos pressupostos de Lévi-Strauss (1975), que observa que numa ciência onde o observador é da mesma natureza que o objeto, o observador, ele mesmo, é uma parte de sua observação, o que reforça a idéia de que a neutralidade da investigação científica é um mito. Desta forma, é necessário tornar explícito as impressões dessa experiência. 
Assim, esse momento pareceu marcado pela cisão entre do grupo de trabalhadores, que não foram declaradas verbalmente. Não foi possível captar o que efetivamente desencadeou o processo de substituição da chefia, uma vez que os atores sociais ali presentes, assumiram partido ora de uma e de outra, o que comprometeu a emissão de julgamentos.

Deste modo, as divergências individuais tomaram proporções coletivas, mediante a mobilização de outros trabalhadores que, unidos num mesmo propósito, conseguiram articular a transferência do cargo. Este processo, por um lado, fortaleceu os profissionais que se organizaram em prol de, um único objetivo, que foi alcançado, mas também enfraqueceu um trabalho que estava sendo desenvolvido, gerando a ruptura das ações conjuntas que haviam sido propostas.

Deste modo, o contexto apresentou a assunção de atribuições por uma nova chefia que havia sido empossada há 48horas antes deste último encontro do grupo. Em decorrência disto e, conforme colocado pela própria enfermeira que assumiu a chefia do Serviço, ela ainda estava "tentando entender as coisas", ao mesmo tempo em que referia estar muito feliz por ter assumido a chefia da Divisão de Enfermagem, com o apoio demonstrado por todos os trabalhadores que estavam presentes no momento da posse.

Foi perceptível o misto de sentimentos vivenciados por esta enfermeira em relação ao momento pelo qual estava passando. Assim, esta enfermeira, assumindo o gerenciamento do Serviço, não pareceu diferente das demais categorias de enfermagem, ao mostrar, também, sua exposição aos 
processos potencializadores e destrutivos do ambiente de trabalho. Este perfil está de acordo com a proposição de Lima Junior e Esther (2001), no qual o sofrimento e o prazer são provenientes da dinâmica interna das situações e da organização do trabalho, ou seja, são produtos dessa dinâmica, das relações subjetivas de poder, das condutas e ações dos trabalhadores permitidas pela organização do trabalho.

Entretanto, o que chama a atenção é que, no exato momento, o que emergiu foram, predominantemente, os fatores destrutivos. Isto evidenciado na própria fala da participante:

“... eu estava muito apreensiva, inclusive tive uma queda da imunidade, cheguei a ter faringite, e depois da posse a faringite passou!" (Alexander Scriabin)

A carga psíquica que este trabalhador estava sofrendo devido à mudança de cargo e atribuições, dentro da situação de conflito, desencadeou manifestações, além da tensão, estresse e ansiedade, manifestação fisiológica. Isso evidencia que o enfermeiro gerencial, mesmo sendo responsável pela promoção de um ambiente o mais saudável possível, também sofre o impacto psíquico das demandas de sua função.

Assim, a discussão de proposições para intervenção na realidade dos trabalhadores de enfermagem perdeu seu interesse no momento porque emergiu outra situação, que polarizou a discussão sem possibilidade de retomada. A enfermeira que havia transferido o cargo e havia participado dos primeiros 
encontros abandonou a reunião nos primeiros 20 minutos e a recém-empossada não tinha conhecimento do trabalho que estava em andamento. Ou seja, aquela que tinha o conhecimento do processo não possuía mais a governabilidade para intervenção e a atual detentora do poder de decisão não tinha o conhecimento das discussões anteriores.

A própria enfermeira colocou suas expectativas quanto este novo momento vivenciado e quanto à sua colaboração no processo de promoção da QVT:

“... o que a gente tá tentando fazer é incentivar, fomentar essa parte de produção científica (...) eu acho que agora é o tempo certo para mudanças, porque nós vemos um pessoal bem novo, que foram nossos alunos, eu tenho pensado nisso, em nos reunirmos, nos articularmos, vamos ver se a gente consegue... faz dois dias que eu assumi, eu falo muito da enfermagem porque eu sou daqui da equipe de enfermagem $e$ também tenho livre acesso pois dou aula na universidade, e quando eu assumi eu falei pros outros professores que eles são co-responsáveis. Eu tô contanto com isso, eles vão ter de vir pra cá, eles vão ter de por a mão na massa, vão ter de mostrar serviço aqui também. Então eu acho que é o momento de nós fazermos alguma coisa pra incentivar, motivar os enfermeiros e, conseqüentemente estes, como chefes de equipe, os auxiliares e técnicos de enfermagem (...) neste trabalho aí você mostrou muita coisa que eu não tinha atentado... tem muita gente cuidado dos pacientes, mas a gente mesmo ninguém cuida!" (Alexander Scriabin)

A fala explicita um novo perfil gerencial, que vai buscar a integração enfermeiro docente-assistencial como forma de integrar as ações e buscar o conhecimento científico para embasar as ações. Entretanto, estava tudo muito incipiente, e as falas colocadas referiam-se às expectativas e não à ação necessária para intervenção propriamente dita. 
A tensão demonstrada pela participante e o estresse de poucos dias de cargo relacionam-se à constatação de Leitão (2002), que refere que as enfermeiras são submetidas às cargas de trabalho para atingir metas institucionais. Entretanto, Murofuse, Abranches, Napoleão (2005) referem que é exatamente com a diminuição do estresse que alguns objetivos organizacionais podem ser alcançados.

Assim, diante de um cenário que não dispõe de programas direcionados à promoção da saúde e QVT, as estratégias de enfrentamento adotadas pelo grupo constituem-se em estratégias individuais e não de um modo coletivo à Instituição (Carvalho, Felli, 2006).

Essa situação talvez exemplifique o que acontece nas situações reais de trabalho, quando o gerenciamento das situações emergentes polarizam a atenção, as energias e o foco do trabalho. Nesse sentido, as propostas de promoção da qualidade de vida dos trabalhadores parece ser uma decisão que "fica para depois" e, dificilmente entra na agenda de discussões porque, sabidamente, existem assuntos que exigem decisões mais imediatas. 


\section{CONCLUSÕES}

Este estudo teve como objetivo conhecer quais a ações são desenvolvidas visando a promoção da qualidade de vida no trabalho, no âmbito gerencial. Para isso, foi realizada uma construção de conceitos e temas para discussão, de forma a recompor o processo saúde-doença dos trabalhadores de enfermagem. Assim, buscou-se compreender quais os fatores potencializadores e destrutivos da saúde no ambiente do trabalho, qual o significado de qualidade de vida no trabalho para os atores sociais que compõem a realidade estudada, quais as ações estão sendo desenvolvidas, em diferentes níveis gerenciais, voltadas a QVT e, a partir daí, buscar propostas que intervenham na problemática vivenciada.

O estudo desenvolveu-se na abordagem qualitativa, fundamentado no referencial teórico-metodológico do materialismo histórico e dialético e na determinação social do processo saúde-doença.

A partir dos pressupostos teóricos propostos para o presente estudo, foi realizada uma reconstrução dos processos de trabalho de enfermagem (assistencial e gerencial), decomposto nos elementos objeto, meios e instrumentos e organização do trabalho, contextualizado na determinação social que confere historicidade a esses processos. Deste modo, a análise parte da 
lógica capitalista neoliberal, da apreende-se o trabalho, como determinante dos processos favoráveis e destrutivos da saúde no momento de trabalho.

A apreensão do objeto de trabalho ocorreu a partir das atividades realizadas e evidenciou dois processos de trabalho - assistencial e gerencial. São nas interações estabelecidas entre os elementos que compõem o trabalho que é construída a qualidade de vida no trabalho. Entretanto, os dados permitiram a apreensão de que as contradições, entre os processos favoráveis e destrutivos no trabalho, tem gerado a predominância do pólo destrutivo, configurado pela exposição às diversas cargas de trabalho, geradoras dos processos de desgaste.

Foram analisados os acidentes de trabalho notificados no SESMT nos anos de 2004 e 2005. A enfermagem apresentou um decréscimo em relação ao primeiro e o segundo ano de estudo, passando de $51 \%$ para $25 \%$ em relação ao total de acidentes notificados, sendo o auxiliar de enfermagem a categoria que mais sofreu acidentes de trabalho no período analisado.. Aproximadamente $90 \%$ das causas de acidentes de trabalho foram devidas a acidentes com materiais perfuro-cortantes.

A reconstrução dos processos de trabalho ocorreu pela decomposição dos elementos de trabalho. $\mathrm{O}$ objeto de trabalho foi construído a partir das atividades realizadas pelos trabalhadores, que resultaram em dois objetos distintos: o primeiro objeto, relacionado ao processo assistencial é identificado como os pacientes e familiares; o segundo objeto, relacionado ao processo gerencial, refere-se às demandas dos trabalhadores de enfermagem. Os meios e 
instrumentos necessários para a transformação do objeto de trabalho foram os materiais e equipamentos de assistência à saúde, bem como o conhecimento técnico e prático; o próprio trabalhador foi referido como sendo um meio para a realização do cuidado, sob a ótica da gerência.

A partir do processo de trabalho, foi possível evidenciar a divisão entre aqueles que planejam as ações e aqueles que as executam, sendo que ambos priorizam a assistência ao paciente, mesmo diferindo quanto ao objeto de trabalho. A organização do trabalho ocorre de forma hierarquizada, com algumas esferas de flexibilização de decisões e compartilhamento de poder entre os membros da equipe. As falas dos sujeitos evidenciaram as relações como sendo o determinante do processo saúde-doença no trabalho, sendo que foram apresentados fatores favoráveis e destrutivos decorrentes desta interação. Assim, apreende-se que a qualidade de vida no trabalho é proporcionada na interface entre os aspectos que ora favorecem e ora comprometem à saúde, identificados no tripé das relações que são estabelecidas: com o pacientes, com os demais trabalhadores da saúde e com a instituição.

O significado de qualidade de vida para os sujeitos da pesquisa foi apreendida em três dimensões: a primeira, como a satisfação das necessidades humanas básicas, como alimentar-se, vestir-se, ter acesso à educação, saúde, saneamento básico, moradia e lazer; a segunda, relacionada à satisfação em fazer o que se gosta, ou seja, trabalhar com o que lhe proporciona prazer e ser 
reconhecido pelo seu trabalho; a terceira refere-se à inserção social conferida pelo trabalho, que permite o acesso aos bens de consumo e serviços.

A principal motivação que justifica a permanência dos trabalhadores no ambiente de trabalho foi apontada como a satisfação em desempenhar o trabalho, porque a profissão foi escolhida pelo gostar de cuidar das pessoas. Em seguida, aparece o relacionamento que é estabelecido com os pacientes e demais membros da equipe de enfermagem. As falas são claras quanto à importância atribuída ao paciente e a sua resposta ao cuidado prestado (que não necessariamente traduz-se em alta ou cura) e às relações de confiança e cumplicidade que são estabelecidas com os demais trabalhadores da equipe de enfermagem, variáveis que configuram um ambiente saudável.

Em relação às ações voltadas à QVT, os sujeitos referiram a não existência de programas direcionados à saúde no trabalho, sendo que a Instituição assume uma postura de desconhecimento total frente ao tema proposto, enquanto as iniciativas dos gerentes de enfermagem limitam-se em corresponder às demandas que são apresentadas. O único setor do hospital que se responsabiliza com o trabalhador é o SESMT, que realiza os exames periódicos, notificações de acidentes de trabalho, orientações quanto a prevenção de riscos de acidentes e disponibiliza atendimento de médicos e psicólogos aos trabalhadores, com horário agendado.

Os processos favoráveis presentes no ambiente de trabalho são os mesmos que motivam os trabalhadores para o desempenho de suas atribuições, 
sendo destacados novamente a valorização e reconhecimento profissional, as relações estabelecidas com os pacientes e demais profissionais da saúde e a possibilidade de inserção social, conferida pelo trabalho.

Os processos destrutivos presentes no ambiente de trabalho foram caracterizados pela exposição do trabalhador às cargas de trabalho (biológicas, mecânicas, químicas, físicas, fisiológicas e psíquicas) e os processos de desgaste decorrentes desta exposição. Os processos que deterioram a saúde estão presentes em todas as unidades de trabalho e refletem, indistintamente, na exposição às cargas psíquicas. Desta forma, a ênfase foi dada na interferência das cargas psíquicas no desenvolvimento e manutenção da saúde e conseqüente QVT.

Os processos de trabalho apresentam o desequilíbrio entre os fatores favoráveis e destrutivos, sendo que a prevalência dos fatores destrutivos tem delineado o perfil de morbidade do grupo. Assim, mesmo sob os danos causados pelo trabalho, os fatores favoráveis e motivadores continuam estimulando os trabalhadores de enfermagem à execução de suas funções. Conduto, a não existência de intervenções direcionadas à transformação desta realidade pode gerar o adoecimento crônico dos trabalhadores e afastamento do trabalho por motivo de doenças ocupacionais.

A instituição, inserida na lógica capitalista de produção, não investe em ações promotoras da QVT, isentando-se da responsabilidade frente aos profissionais. Entretanto, quando se analisa a gerência de enfermagem, identifica- 
se, por sua vez, que esta lança mão de iniciativas de ordem pontual e paliativa, de acordo com a demanda dos trabalhadores. Diante desta postura, o estudo propôs a discussão de um redirecionamento das ações de enfermagem, de forma que fosse priorizada a saúde dos trabalhadores.

Contudo, o contexto de trabalho apresentado não permitiu o cumprimento de tal objetivo, uma vez que o hospital passava por um período de transição na chefia da Divisão de Enfermagem. Este fato, desencadeado pela interjeição de um grupo de trabalhadores insatisfeitos com o modelo gerencial vigente, confrontou posições distintas de liderança, gerando um cenário sensível e despreparado para a proposição de mudanças.

Assim, percebeu-se que a função gerencial em enfermagem não tem desempenhado seu papel de articulador entre equipe e instituição; somado a isso, a própria instabilidade do cenário colaborou para o aparecimento do desgaste psíquico na gerente de enfermagem, que somatizou sua dor mental em manifestação fisiológica. Deste modo, as implicações e cobranças dos processos de trabalho junto à chefia de enfermagem roubam o foco de atenção deste enfermeiro, que deveria estar centrado nos trabalhadores.

Ou seja, se por um lado os trabalhadores de enfermagem da Instituição mostram que tem força para defesas coletivas e para a substituição de pessoas em cargos, por outro evidencia a insatisfação conquistada pela chefia que permitiu tal extremo. Portanto, esta desarticulação fragiliza a chefia de enfermagem frente aos demais trabalhadores. A sobrecarga psíquica foi evidenciada como decorrente 
das cobranças bilaterais sofridas pela enfermeira, que precisa dar conta das divergentes necessidades da organização e dos trabalhadores.

Assim, a desestruturação apresentada pelo cenário, o desconhecimento do projeto pela recém-empossada chefia de enfermagem, o clima constrangedor, originado pela saída de um enfermeiro e a indicação de outro, maquiaram as possibilidades de intervenção da realidade. Devido ao período de mudança apresentado que, segundo as falas, emergia outras prioridades como a própria adaptação e aprofundamento acerca dos processos de trabalho intra-hospitalar.

Estes resultados demonstram a necessidade de desenvolvimento de instrumentos que subsidiem as intervenções de da gerência na promoção da qualidade de vida dos trabalhadores de enfermagem, de forma a instrumentalizar e capacitar os enfermeiros que assumem o gerenciamento, frente às necessidades de saúde-doença, muitas vezes desapercebidas no paradoxal cenário dos processos favoráveis e destrutivos da saúde dos trabalhadores.

Esta realidade, certamente única, mas não isolada, também tem sido diagnosticada em outros países, conforme colocado por llmarinen, pesquisador da área de qualidade de vida no trabalho da Finlândia, no $I C O H$ 2006: se há alguém que deve se responsabilizar pela qualidade de vida dos trabalhadores, é o trabalhador que desempenha a supervisão junto à equipe. 


\section{Referências}

Almeida MCP de, Rocha SMM (organizadoras). O trabalho de enfermagem. São Paulo: Cortez; 1997.

Almeida CB, Pagliuca LMF, Leite ALAS. Acidentes de trabalho envolvendo os olhos: avaliação de riscos ocupacionais com trabalhadores de enfermagem. Rev Latino-am Enfermagem 2005; 13(5): 708-16.

Alexandre NMC. Aspectos ergonômicos relacionados com o ambiente e equipamentos hospitalares. Rev Lat-am Enfermagem 1998; 6(4): 103-9.

Araújo TM, Aquino E, Menezes G, Santos CO, Aguiar L. Aspectos psicossociais do trabalho e distúrbios psíquicos entre trabalhadoras de enfermagem. Rev Saúde Pública 2003; 37(4): 424-433.

Batista KM, Biachi ERF. Estresse de enfermeiro em unidade de emergência. Rev Latino-am Enfermagem 2006; 14(4): 534-9.

Balsamo AC, Felli VEA. Estudo sobre os acidentes de trabalho com exposição aos líquidos corporais humanos em trabalhadores da saúde de um hospital universitário. Rev Latino-am Enfermagem 2006; 14(3): 346-53.

Barachatti VS, Felli VEA. A exposição dos graduandos de enfermagem aos fluídos corpóreos durante a realização dos estágios. [monografia] São Paulo (SP): Escola de Enfermagem da USP; 2005.

Baraldi S. Supervisão, flexibilização e desregulamentação no mercado de trabalho: antigos modelos de controle, novas incertezas nos vínculos de trabalho da enfermagem [doutorado] São Paulo (SP): Escola de Enfermagem da USP; 2005. 
Barboza DB, Soler ZASG. Afastamentos do trabalho na enfermagem: ocorrências com trabalhadores de um hospital de ensino. Rev Latino-am Enfermagem 2003;11(2):177-183.

Brasil. Lei n. 8.112, de 11 de dezembro de 1990. Dispõe sobre o regime jurídico dos servidores civis da União, das autarquias e das fundações públicas federais. Diário Oficial da República Federativa do Brasil, Brasília, 19 abr. 1991.

Brasil. Lei n. 8.213, de 24 de julho de 1991. Dispõe sobre os planos de benefícios da Previdência Social e dá outras providências. Diário Oficial da República Federativa do Brasil, Brasília, 14 ago. 1991.

Brasil. Lei n. 6.514, de 22 de setembro de 1977. Altera o capítulo V, do tótulo II da Consolidação das Leis do Trabalho, relativo a segurança e medicina do trabalho e dá outras providencias. Diário Oficial da República Federativa do Brasil, Brasília, 23 dez. 1977.

Brasil. Decreto-lei n. 5.452 de $1^{\circ}$ de maio de 1943. Aprova a Consolidação das Leis do Trabalho. Diário Oficial da República Federativa do Brasil, Brasília, 9 ago. 1943.

Brasil. Conselho Nacional de Saúde. Resolução n. 196, de 10 de outubro de 1996. Aprova as diretrizes e normas regulamentadoras de pesquisas envolvendo seres humanos. Termos de Decreto de Delegação de Competência 12 nov. 1991.

Brasil. Portaria 1.675, de 06 de outubro de 2006. Estabelece orientações para procedimentos operacionais a serem implementados na concessão de benefícios de que trata a Lei 7.112/90 e Lei 8.572/97, que abrange processos de saúde e dá outras provicências.

Breilh J. La pobreza urbana y la salud: una mirada desde la epidemiologia crítica. In: Anais do Congresso Brasileiro de Epidemiologia 1990; Campinas; Abrasco; 1990. p. 281-302. 
Breilh J, Granda E. Saúde na sociedade: guia pedagógico sobre um novo enfoque do método epidemiológico. São Paulo: Cortez; 1989.

Breilh J. La salud enfermedad como hecho social: un nuevo enfoque. In: Breilh J et all. Deterioro de la vida: un instrumento para análisis de prioridades regionales in lo social y la salud. Quito, CEAS/Corporación: Editora Nacional, 1990.

Breilh J. Epidemiologia: economia, política e saúde. São Paulo, HUCITEC, 1991.

Breilh J. Nuevos conceptos y técnicas de investigación: guía pedagógica para un taller de metodología. 2 ed. Quito, CEAS, 1995.

Breilh $\mathrm{J}$ et al. Deterioro de la vida: um instrumento para analisis de prioridades regionales em lo social y la salud. Quito: CEAS, 1990.

Campos GWS. Subjetividade e administração de pessoal: considerações sobre modos de gerenciar trabalho em equipes de saúde. In: Merhy EE, Onocko R. (organizadores) Agir em saúde: um desafio para o público. São Paulo: Hucitec, 1997.

Canini SRMS, Gir E, Hayashida M, Machado AA. Acidentes perfurocortantes entre trabalhadores de enfermagem de um hospital universitário no interior paulista Rev. Latino-Am. Enfermagem, 2002 março-abril: 10(2): 172-8.

Canini SRMS, Gir E, Machado AA. Accidents with potentially hazardous biological material among workers in supporting services, Rev. Latino-Am. Enfermagem, 2005 julho-agosto: 13(4): 496-500.

Catellanos BEP et al. Os desafios da enfermagem nos anos 90. In: Anais do $41^{\circ}$ Congresso Brasileiro de Enfermagem 1989; Florianópolis; 1989, p.47.

Cattani AD (organizador). Trabalho e tecnologia: dicionário crítico. Petrópolis: Vozes; Porto Alegre: Editora da Universidade Federal RGS; 1997; p. 101-14. 
Carvalho MB de, Felli VEA. O trabalho de enfermagem psiquiátrica e os problemas de saúde dos trabalhadores. Rev Latino-am. Enfermagem 2006; 14(1): 61-9.

Chiesa AM, Ciampone MHT. Princípios gerais para abordagem de variáveis qualitativas e o emprego da metodologia de grupo focais. Brasília: Classificação Internacional das Práticas em Saúde Coletiva; 1999; p.306-24.

Costa TF, Felli VEA. Exposição dos trabalhadores de enfermagem às cargas químicas em um hospital público universitário da cidade de São Paulo. Rev Latinoam Enfermagem 2005; 13(4): 501-8.

Cruz EBS. Estudo sobre a problemática de saúde dos trabalhadores de enfermagem: perspectivas para vigilância à saúde. [dissertação] São Paulo (SP): Escola de Enfermagem da USP; 2006.

Dejours C. Abdoucheli E, Jayet C. Psicodinâmica do trabalho: contribuições da escola dejourinana à análise da relação prazer, sofrimento e trabalho. São Paulo: Atlas, 1994, cap. 1.

Elias MA, Navarro VL. A relação entre o trabalho, a saúde e as condições de vida: negatividade e positividade no trabalho das profissionais de enfermagem de um hospital escola. Rev Latino-am Enfermagem 2006; 14(4): 517-25.

Faria TMA, Silva RDM, Patrício ZM. Homem-bagaço: a qualidade de vida dos trabalhadores aposentados de enfermagem numa abordagem ecosófica. Texto e Contexto Enferm 1999; 8(3): 200-12.

Felli VEA, Ciampone JT. O resgate do conhecimento sobre a saúde do trabalhador de enfermagem. Livro programa Águas de Lindóia: Escola de Enfermagem da USP; 2002; p. 251. 
Felli VEA, Peduzzi M. O trabalho gerencial em enfermagem. In: Kurcgant $P$ (coord). Gerenciamento em Enfermagem; 2005: 1-13.

Felli VEA, Tronchin DMR. A qualidade de vida no trabalho e a saúde do trabalhador de enfermagem. In: Kurcgant $P$ (coord). Gerenciamento em Enfermagem; 2005: 89-107.

Felli VEA. Monitoramento da saúde dos trabalhadores de enfermagem: promovendo a qualidade de vida no trabalho. [relatório parcial de pesquisa] São Paulo: Escola de Enfermagem da USO; 2004.

Gelbecke FL. Qualidade de vida e organização do trabalho: questões relevantes para a enfermagem. In: Cianciarullo TI, Corneta VK. Saúde, desenvolvimento e globalização: um desafio para os gestores do terceiro milênio. São Paulo: Ícone; 2002, p. $199-227$

Gurgueira GP, Alexandre NMC, Corrêa Filho HR. Prevalência de sintomas músculo-esqueléticos em trabalhadoras de enfermagem. Rev Latino-am. Enfermagem 2003; 11(5): 608-13.

Gutierrez BAO. O processo de morrer no cotidiano do trabalho dos profissionais de enfermagem de unidades de terapia intensiva. [doutorado] São Paulo (SP): Escola de Enfermagem daUSP; 2003.

Lacaz FAC. Qualidade de vida no trabalho e saúde/doença. Ciência \& Saúde Coletiva 2000; 5(1): 151-61.

Laurell AC, Noriega M. Processo de produção em saúde: trabalho e desgaste operário. São Paulo: Hucitec; 1989. 
Leitão RER. A qualidade nos serviços de enfermagem segundo a percepção de enfermeiras que vivenciam essa prática. [doutorado] São Paulo (SP): Escola de Enfermagem da USP; 2002, 161.

Lima Junior JHV, Ésther AB. Transições, prazer e dor no trabalho de enfermagem. Rev Adm Empresas 2001; 41(3): 20-30.

Mandu ENT, Almeida MCP. Necessidades em saúde: questões importantes para o trabalho da enfermagem. Rev Bras Enferm 1999; 52(1): 54-66.

Marx K. O capital: crítica da economia política. 8 ed. São Paulo: Difusão Editorial; 1982; v.1; cap. 5.

Marziale MHP, Nishimura KYN, Ferreira MM. Riscos de contaminação ocasionados por acidentes de trabalho com material perfuro-cortantes entre trabalhadores de enfermagem Rev Latino-am. Enfermagem 2004; 12(1): 36-42.

Matos E. Refletindo sobre a qualidade de vida no trabalho da enfermagem no hospital universitário. Texto e Contexto Enfermagem 1999; 8(3): 27-43.

Minayo CSM. O desafio do conhecimento. São Paulo: Hucitec, 8 ed., 2004.

Minayo CSM (org), Deslandes SF, Cruz Neo O, Gomes R. Pesquisa Social: teoria, método e criatividade. Rio de Janeiro: Vozes, 1994.

Mininel VA. Ações gerenciais direcionadas à qualidade de vida no trabalho de enfermagem: a percepção dos enfermeiros. [monografia] São Paulo (SP): Escola de Enfermagem da USP; 2005. 
Mishima SM et al. Organização do processo gerencial no trabalho em saúde pública. In: Almeida MCP, Rocha SMMR. (organizadores) O trabalho de enfermagem. São Paulo: Cortez; 1997; p. 261-96.

Murofuse NT, Abranches SS, Napoleão AA. Reflexões sobre estresse e Burnout e a relação com a enfermagem. Rev Latino-am. Enfermagem 2005; 13(2): 255-261.

Murofuse NT, Marziale MHP. Doenças do sistema osteomuscular em trabalhadores de enfermagem. Rev Latino-am. Enfermagem 2005; 13(3): 364-73.

Napoleão AA, Robazzi MLCC, Marziale MLP, Hayashida M. Causas de subnotificação de acidentes do trabalho entre trabalhadores de enfermagem. Rev Latino-am. Enfermagem 2000; 8(3): 119-120.

Nishide VM, Benatti MCC, Alexandre NMC. Ocorrência de acidente do trabalho em uma unidade de terapia intensiva. Rev Latino-am. Enfermagem 2004; 12(2): 20411.

Nishide VM, Benatti MCC. Riscos ocupacionais entre trabalhadores de enfermagem de uma unidade de terapia intensiva. Rev Esc Enferm USP 2004; 38(4): 406-14.

Oliveira S. A qualidade da qualidade: uma perspectiva em saúde do trabalhador. Cad Saúde Pública 1997; 13(4): 625-34.

Oliveira BRG, Murofuse NT. Acidentes de trabalho e doença ocupacional: estudo sobre o conhecimento do trabalhador hospitalar dos riscos á saúde de seu trabalho. Rev Lat-am Enfermagem 2001; 9(1): 109-15.

Padilha MICS, Souza LNA. Qualidade de vida: reflexão de enfermeiras. Texto \& Contexto Enfermagem 1999; 8(3): 11-29. 
Peduzzi M, Palma JJL da. A equipe de saúde. In: Schraiber LB, Nemes MIB, Mendes-Gonçalves RB. (organizadores) Saúde do adulto: programas e ações na unidade básica. São Paulo: Hucitec, 1996.

Peduzzi M. Equipe multiprofissional de saúde: conceito e tipologia. Rev Saúde Pública 2001; 35(1): 103-9.

Peduzzi M, Anselmi ML. O processo de trabalho de enfermagem: a cisão entre planejamento e execução do cuidado. Rev Bras Enferm 2002; 55(4): 392-98.

Peduzzi M, Schraiber LB. Tendências e possibilidades de investigacão de recursos humanos no Brasil. Revista Educação Médica e Saúde 1993; 27(3): 195313.

Rocha, AM. A saúde do trabalhador de enfermagem sob a ótica da gerência: obstáculos e possibilidades. [doutorado] São Paulo (SP): Escola de Enfermagem da USP; 2003.

Rodrigues MVC. Qualidade de vida no trabalho: evolução e análise no nível gerencial. Petrópolis: Vozes; 1994.

Sarquis LMM. Acidentes de trabalho com instrumentos pérfuro-cortantes: ocorrência entre trabalhadores de enfermagem. [dissertação] São Paulo (SP): Escola de Enfermagem da USP; 1999.

Scudeler LA, Felli VEA. A exposição de graduandos de enfermagem às cargas químicas. [monografia] São Paulo (SP): Escola de Enfermagem da USP; 2006.

Seidl EMF, Zannon CMLC. Qualidade de vida e saúde: aspectos conceituais e metodológicos. Cad Saúde Publica 2004; 20(2): 580-88.

Schimdt DRC, Dantas RAS. Qualidade de vida no trabalho de profissionais de enfermagem, atuantes em blocos cirúrgicos, sob a ótica da satisfação. Rev Lat-am Enfermagem 2006; 14(1): 54-60. 
Silva, VEF da; Kurcgant, P; Queiroz, VM de. O desgaste do trabalhador de enfermagem: relação trabalho de enfermagem e saúde do trabalhador. Rev Bras Enferm 1998; 51 (4): 603-614.

Silva VEAF, Massarollo MCKB. A qualidade de vida e a saúde do trabalhador de enfermagem. O Mundo da Saúde, v.22, n.5, 1998.

Silva VEAF. O desgaste do trabalhador de enfermagem: a relação trabalho de enfermagem e saúde do trabalhador [Tese de doutorado]. São Paulo: Escola de Enfermagem da USP, 1996.

Siqueira MM, Watanabe FS, Ventola A. Desgaste físico e mental de auxiliares de enfermagem: uma análise sob o enfoque gerencial. Rev Latino-am Enfermagem 1995; 3(1): 45-47.

The WHOQOL GROUP. The World Health Organization Quality of Life (WHOQOL) Assessment: development and general psychometric properties. Social Science of Medicine, New York 1998; 46(12): 1569-85.

Vieira DF, Hanashiro DMM. Visão introdutória de qualidade de vida no trabalho. Rev Gaúcha de Enfermagem 1999; 11(2); 41-6.

Xalengati R, Robazzi MLCC, Marziale MHP, Haas VJ. Riscos ocupacionais químicos identificados por enfermeiros que trabalham em ambiente hospitalar. Rev Latino-am Enfermagem 2006 14(2). Disponível em: www.eerp.usp.br/rlae (10 nov 2006) 


\section{ANEXO I}

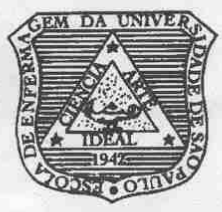

\section{UNIVERSIDADE DE SÃO PAULO ESCOLA DE ENFERMAGEM}

Av. Dr. Enéas de Carvalho Aguiar, 419 - CEP 05403-000

If Fone.: 3066-7548 - Fax.: 280-8213

C.P. 41633 - CEP 05422-970 - e-mail.: edipesq@usp.br

São Paulo, 12 de dezembro de 2003.

$\mathrm{Ilm}^{\mathrm{a}} \mathrm{Sr}^{\mathrm{a}}$

Prof Dra $r^{\text {a }}$ anda Elisa Andres Felli

Ref:: Processo $n^{\circ}$ 339/2003/CEP-EEUSP

Em atenção à solicitação referente à análise do projeto "MONITORAMENTO DA SAÚDE DO TRABALHADOR DE ENFERMAGEM: PROMOVENDO A QUALIDADE DE VIDA NO TRABALHO", informamos que o mesmo foi considerado aprovado pelo Comitê de Ética em Pesquisa da Escola de Enfermagem da Universidade de São Paulo (CEP/EEUSP).

Analisado sob o aspecto ético-legal, atende às exigências da Resolução n ${ }^{\circ}$ 196/96 do Conselho Nacional de Saúde.

Esclarecemos que após o término da pesquisa, os resultados obtidos deverão ser encaminhados ao CEP/EEUSP, para serem anexados ao processo.

Atenciosamente,

Prof ${ }^{a} \mathrm{Dr}^{\mathrm{a}}$ Maria Cnístina Kolnatsu Braga Massarollo

Coordenadora do Comitê de Ética em Pesquisa da

Escola de Enfermagem da Universidade de \$ão Paulo 


\section{ANEXO II}

FORMULÁRIO 1

\section{CARACTERIZAÇÃO INSTITUCIONAL E DOS TRABALHADORES DE ENFERMAGEM}

\section{CARACTERIZAÇÃO INSTITUCIONAL}

- Nome do Hospital:

- Objetivos (descrever):

- № de leitos:

- № de atendimentos:

- Atividades que desenvolve (descrever):

\section{CARACTERIZAÇÃO DOS TRABALHADORES}

- № total de trabalhadores:

- № de trabalhadores de enfermagem:

Enfermeiros:

Técnicos de enfermagem:

Auxiliares de Enfermagem:

Outros. Quais?

\section{COMENTÁRIOS:}




\section{ANEXO III}

FORMULÁRIO 2

\section{QUESTÕES NORTEADORAS PARA A COLETA DE DADOS COM OS TRABALHADORES DE ENFERMAGEM NO GRUPO FOCAL}

1. Como é o trabalho desenvolvido? O que faz, como faz, por quê faz? Como o trabalho é organizado?

2. Quais as cargas de trabalho (biológicas, físicas, químicas, mecânicas, fisiológicas e psíquicas) os trabalhadores de enfermagem estão expostos?

3. Em que situações de trabalho ocorre esta exposição?

4. Quais os problemas de saúde decorrentes dessa exposição (acidentes de trabalho, doenças, desgastes)?

5. Que formas ou estratégias de prevenção podem ser adotadas para a melhoria das condições de saúde e qualidade de vida no trabalho? 


\section{ANEXO IV \\ ENQUETE COLETIVA SOBRE CONDIÇÕES DE TRABALHO}

\section{DADOS DE IDENTIFICAÇÃO}

Unidade:

Categoria:

Representante:

Turno:

2. IDENTIFICAÇÃO DO PROCESSO DE TRABALHO - Responda as perguntas: O que faz? Como faz? Com que faz?

Atividades desenvolvidas:

Materiais e equipamentos utilizados:

Organização do trabalho (subordinação/hierarquia, relações de trabalho e interpessoais; turnos, rodízios, pausas/descansos; divisão do trabalho por categoria, turno, atividade, tempo e área; remuneração): 


\section{IDENTIFICAÇÃO DA EXPOSIÇÃO ÀS CARGAS DE TRABALHO E DESGASTES}

A que cargas de trabalho você se considera exposto? Realizando que atividade? Como essas cargas afetam sua saúde?

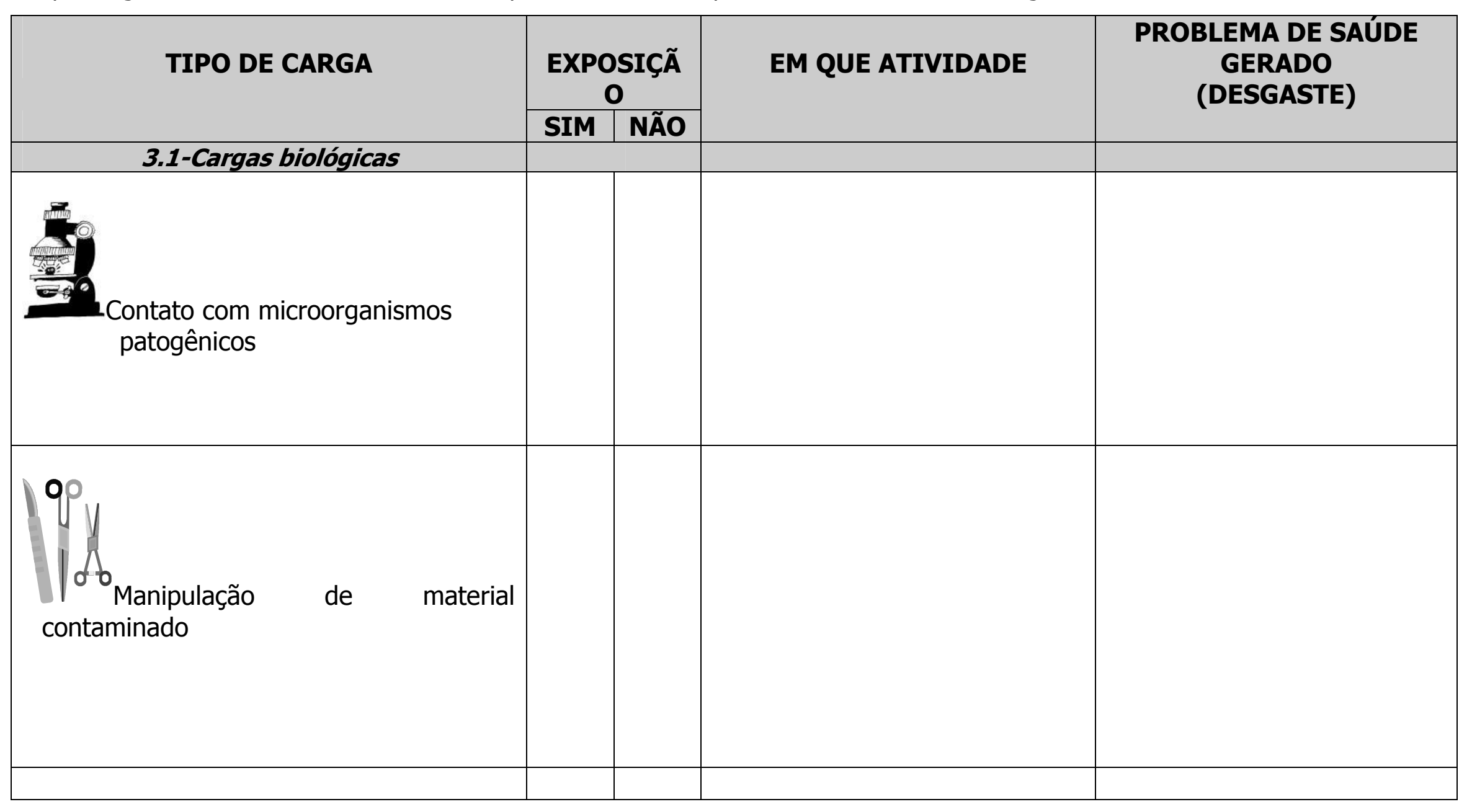




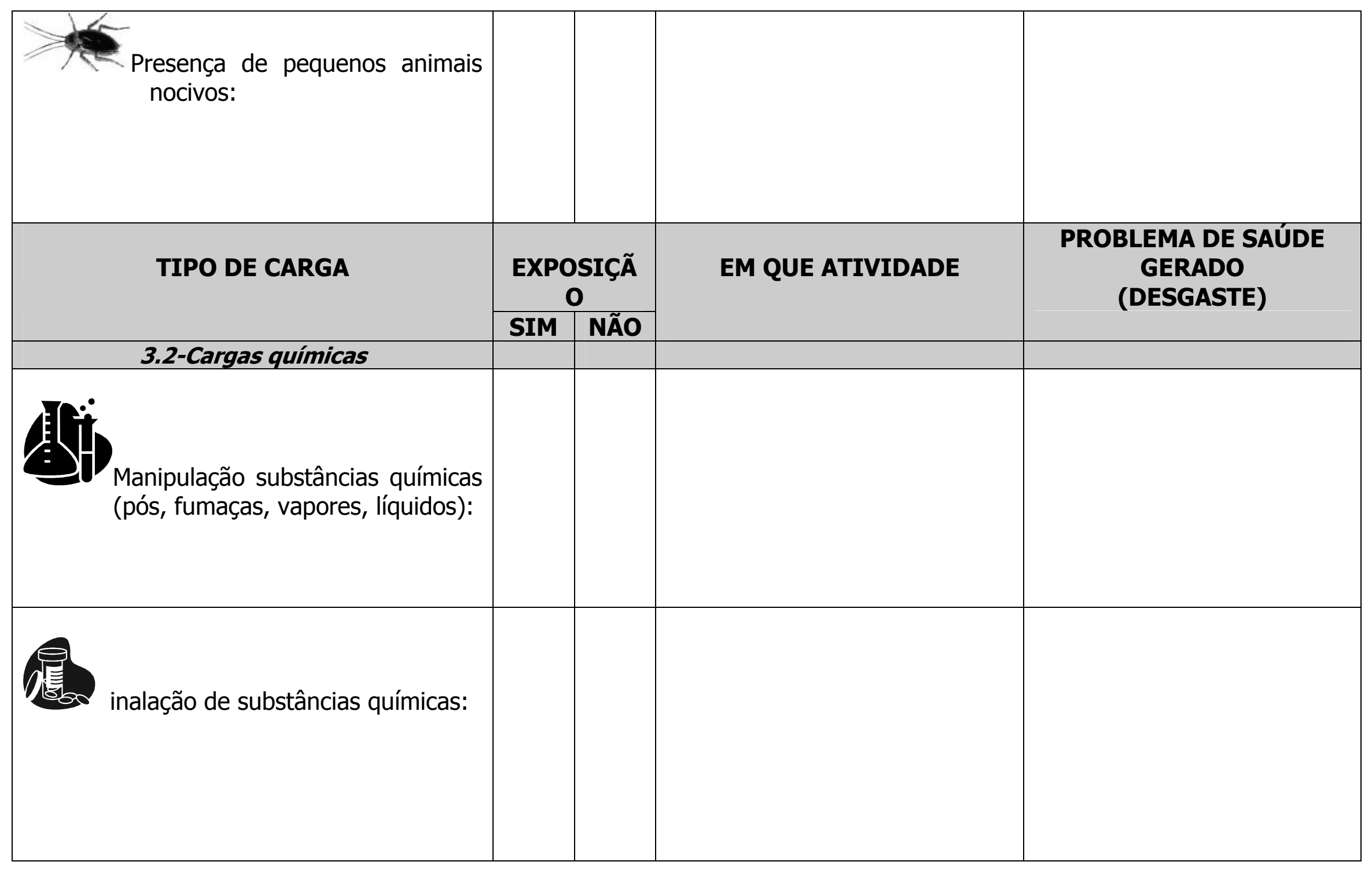




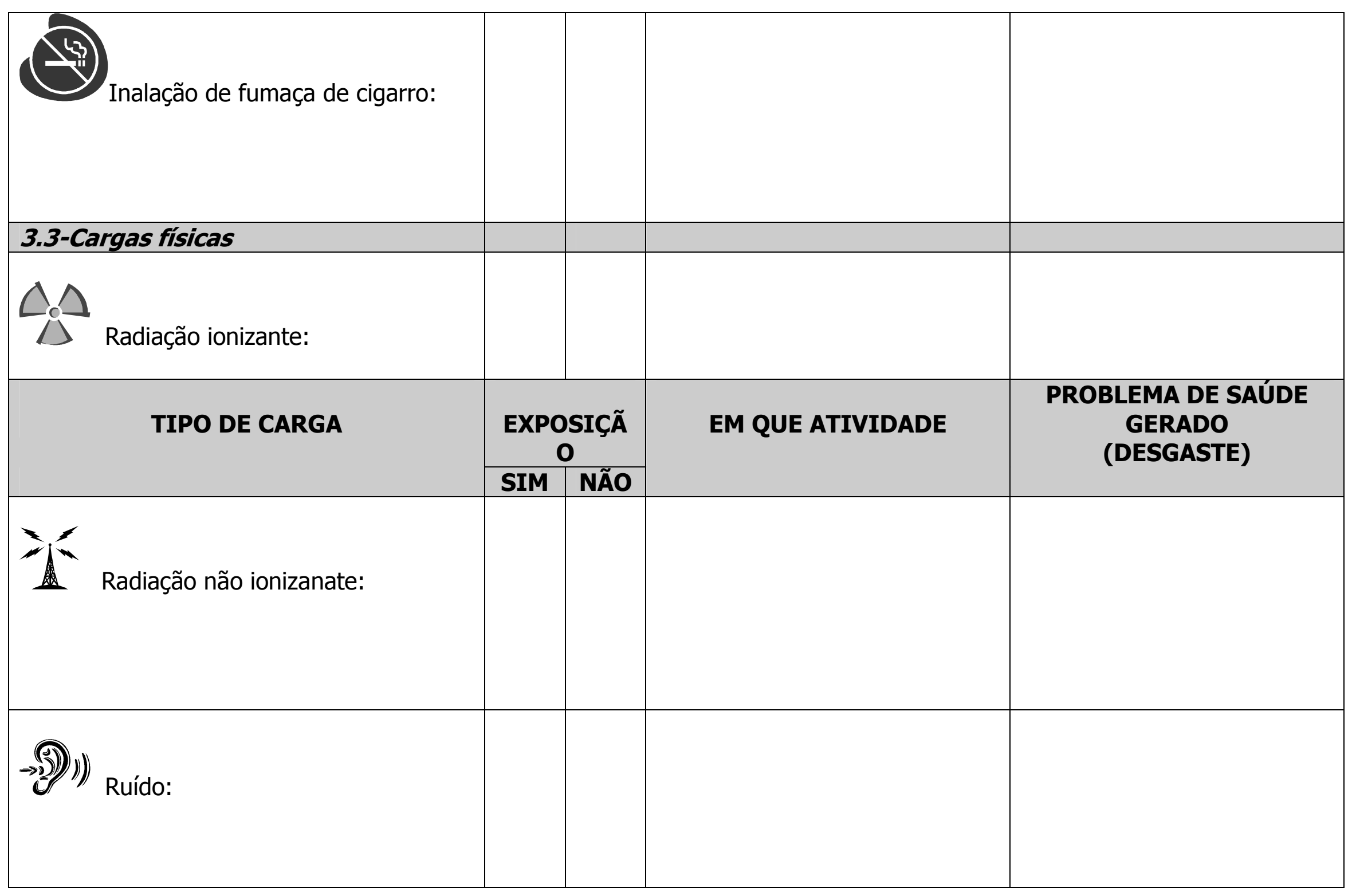




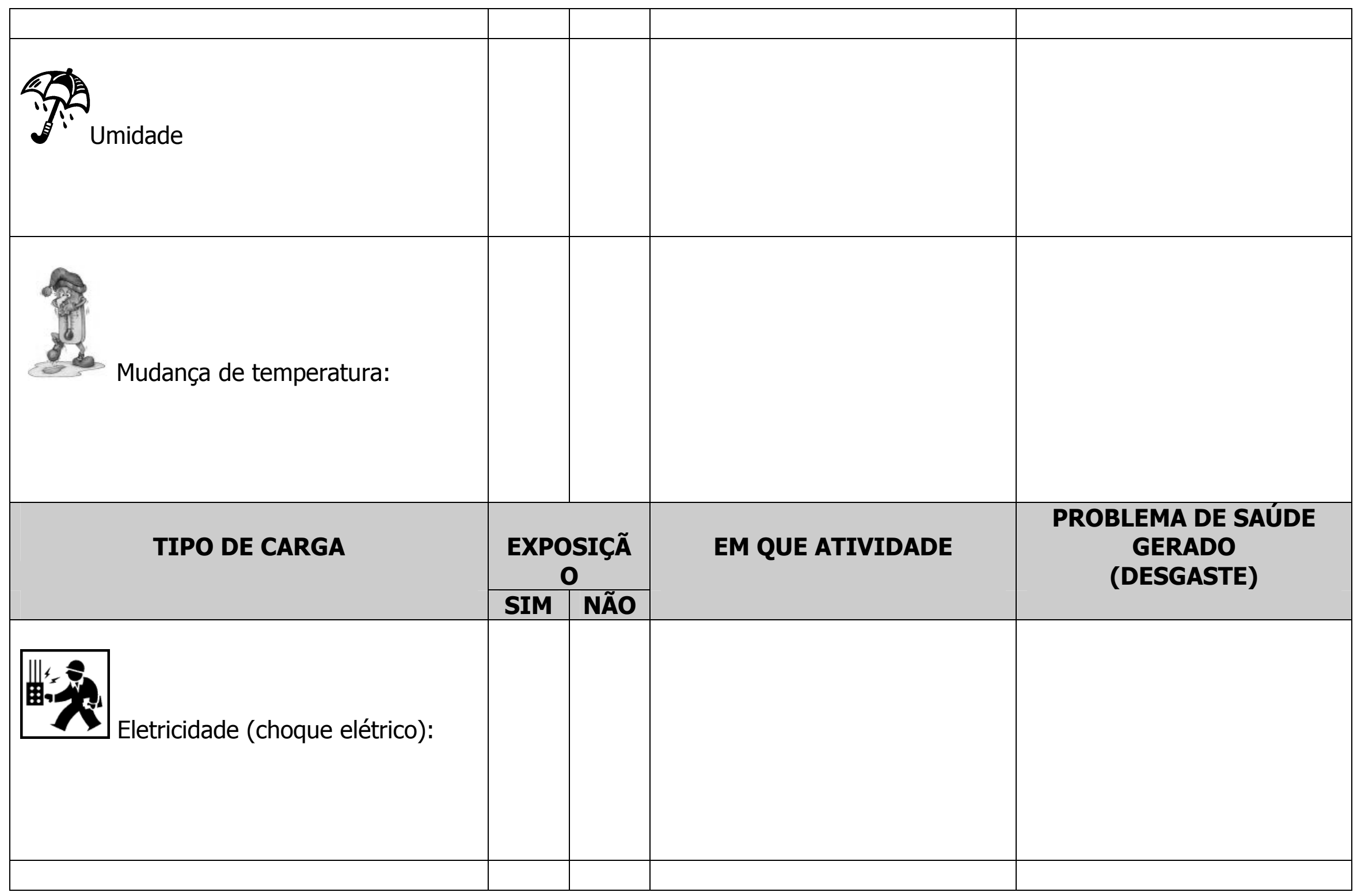




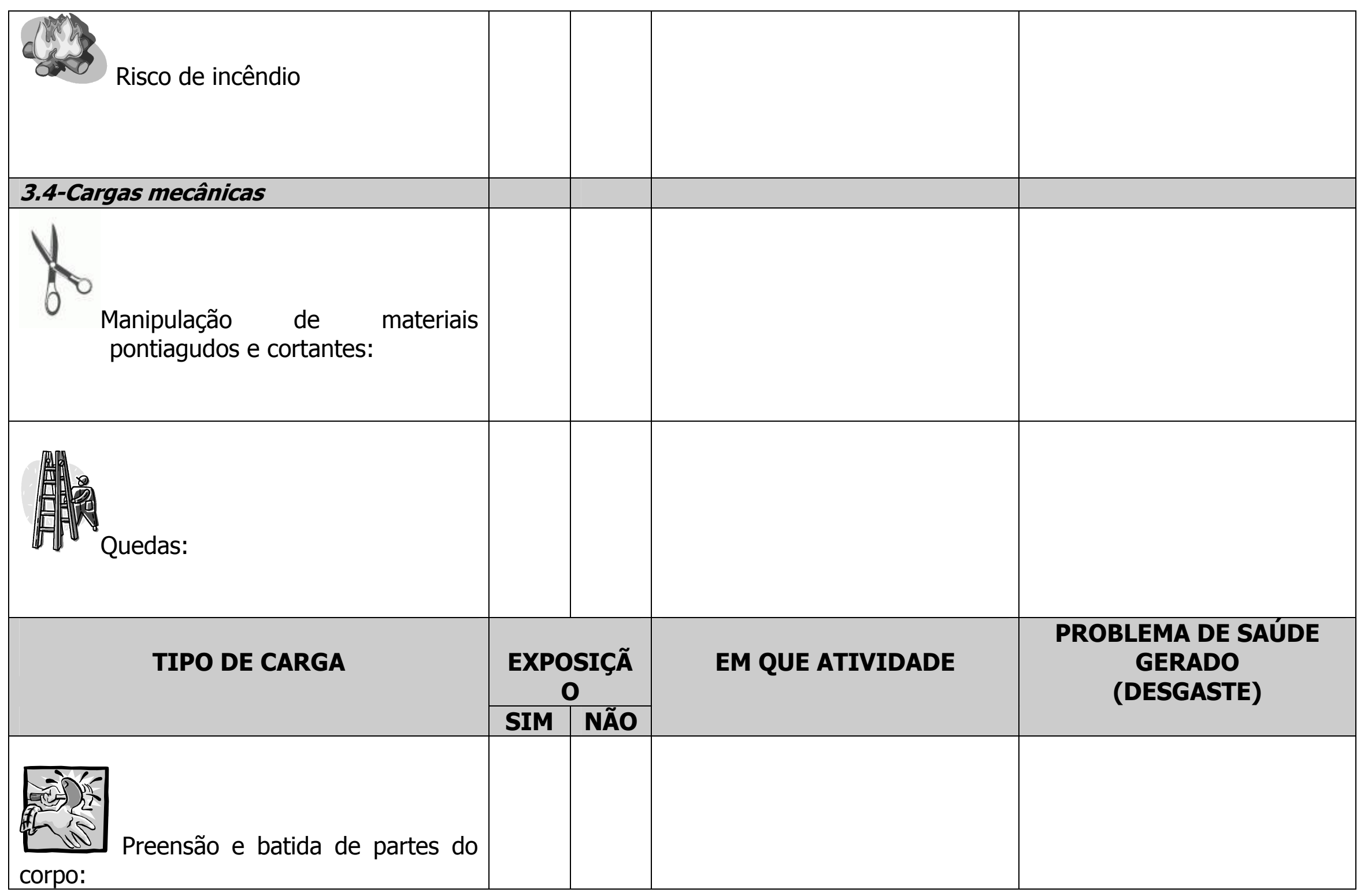




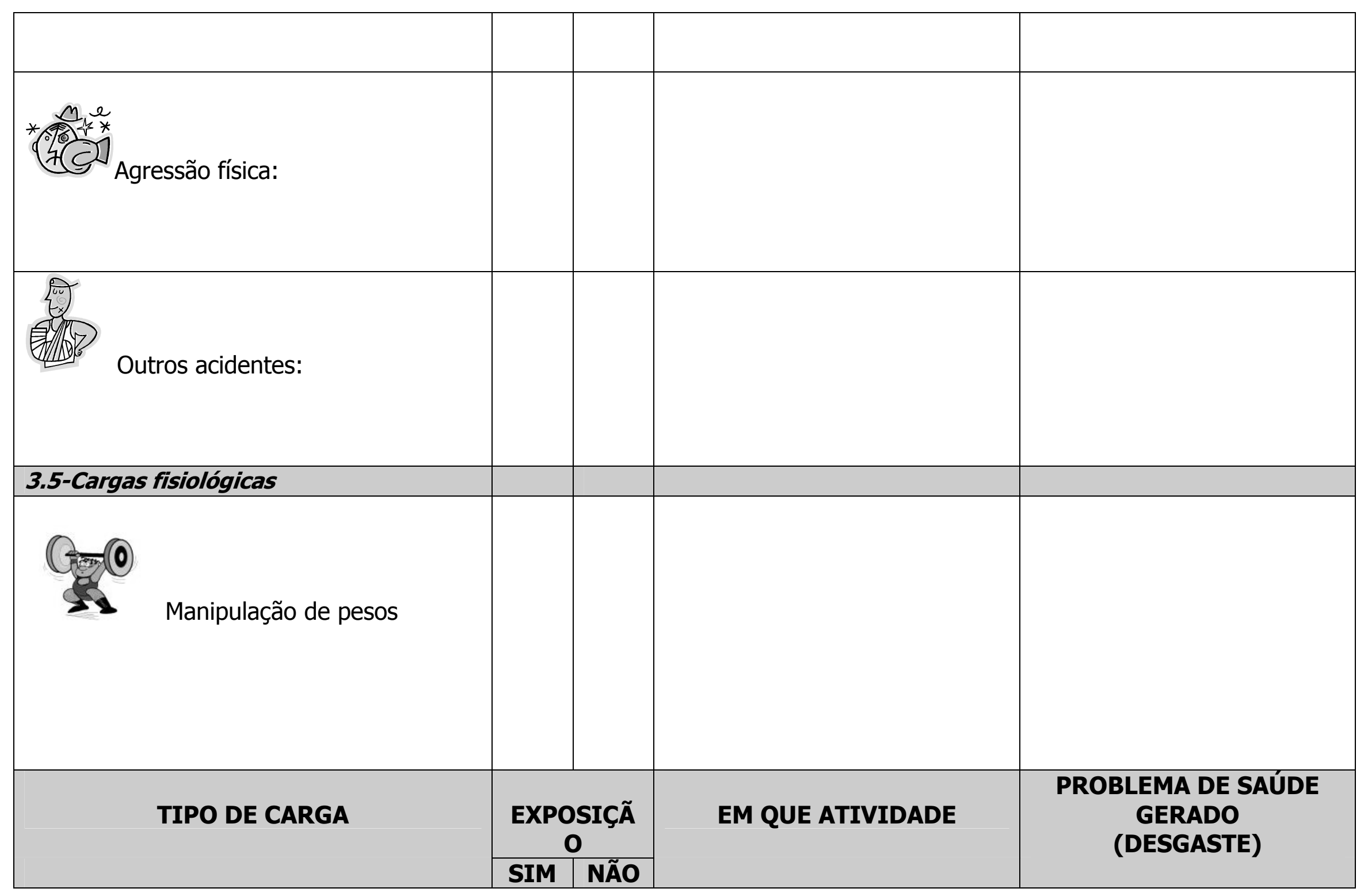




\begin{tabular}{|l|l|l|l|l|}
\hline & & & & \\
\hline
\end{tabular}




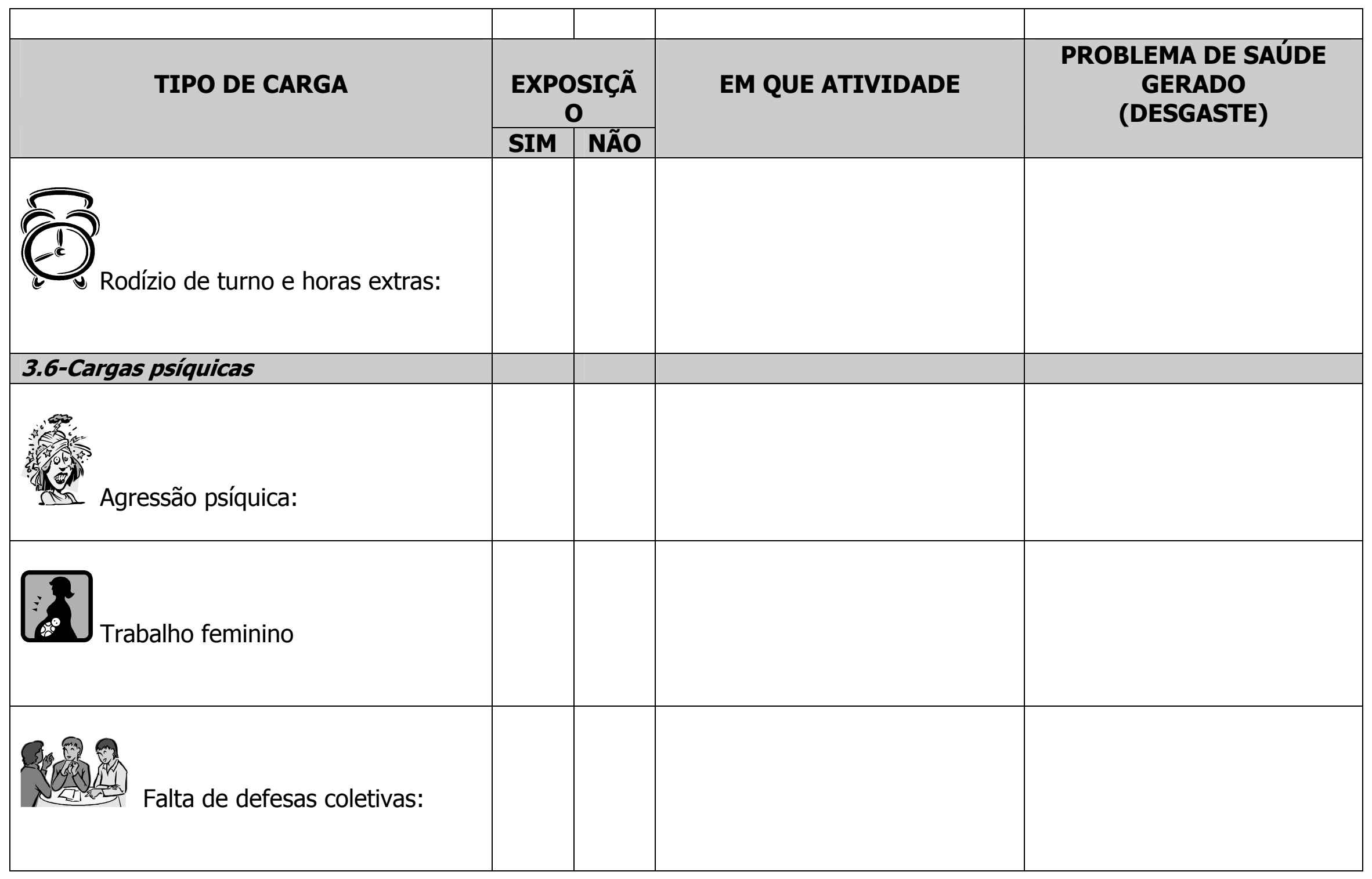




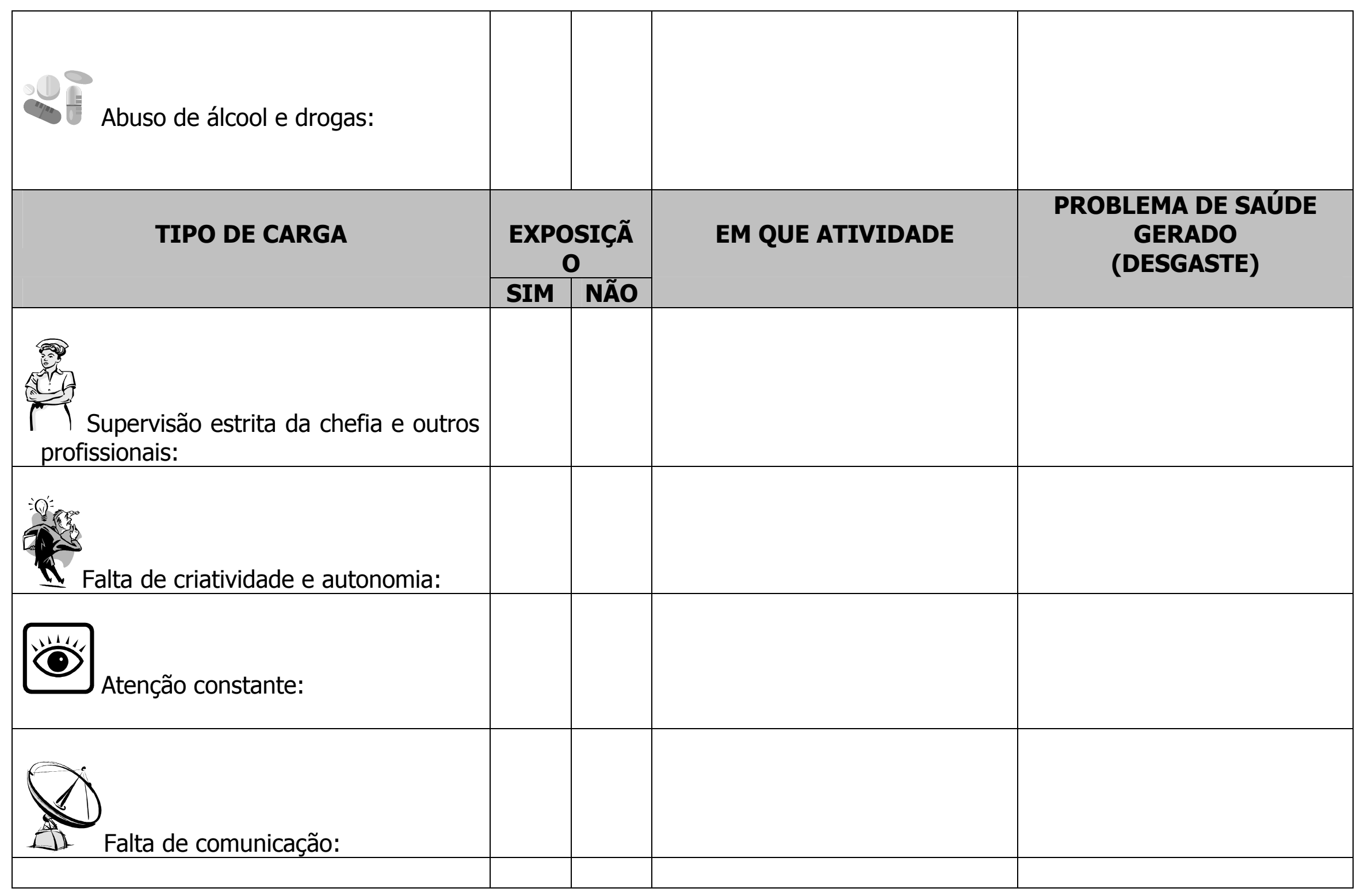


191

\begin{tabular}{|l|l|l|l|l|}
\hline & & & & \\
\hline
\end{tabular}




\begin{abstract}
ANEXO $V$
Questões norteadoras

Primeiro momento: caracterização do processo de trabalho em enfermagem:

>> Abordar a questão: Como é o trabalho de enfermagem (quem faz o quê, utiliza que instrumentos e em que organização de trabalho), mediante as questões:

> como é a organização do trabalho de enfermagem?

> quais as atribuições/tarefas/funções de cada membro da equipe?

> como a equipe de trabalho está dividida?

> quais os instrumentos de trabalho são utilizados?

> como se dão as relações de trabalho na equipe?

> como ocorre a comunicação entre os membros da equipe?
\end{abstract}

Segundo momento: identificar os processos destrutivos e cargas/desgaste no processo de trabalho de enfermagem:

>> Abordar a questão: quais as cargas de trabalho presentes e quais os desgastes geram.

> conte-nos algo que marcou sua vida profissional nesta instituição

> quais as cargas de trabalho que você identifica no seu ambiente de trabalho?

> a quais destas cargas você está submetido?

$>$ você já sofreu algum tipo de acidente de trabalho? Qual?

> você já sofreu algum tipo de desgaste de trabalho? Qual?

> o que te traz sofrimento no ambiente de trabalho?

Terceiro momento: conhecer a concepção de qualidade de vida no trabalho; identificar os processos potencializadores no processo de trabalho; identificar possíveis acões já existentes que proporcionem qualidade de vida no trabalho.

>> Abordar a questão: qual a concepção de qualidade de vida no trabalho; quais os processos potencializadores no ambiente de trabalho; quais as sugestões para a melhoria da saúde no trabalho.

> o que você entende por qualidade de vida no trabalho?

> como está sua qualidade de vida no trabalho?

> que te faz permanecer neste trabalho?

$>$ qual é a motivação que te faz acordar todos os dias para vir trabalhar?

$>$ o que te dá prazer no trabalho?

> o que você sente que tem sido feito para melhor sua qualidade de vida no trabalho?

Quarto momento: produto: buscar intervencões para a realidade apresentada

> baseando-se no perfil de saúde-doença que foi informado pelo grupo, o que você sugere de intervenções que venham a melhorar a qualidade de vida dos trabalhadores de enfermagem?

> como vocês implantariam estas intervenções?

> qual a governabilidade da enfermagem nesta intervenção?

$>$ por onde se começariam as mudanças?

$>$ quais os atores envolvidos neste processo?

$>$ qual a meta a ser alcançada com estas intervenções? 


\section{ANEXO VI \\ TERMO DE CONSENTIMENTO LIVRE E ESCLARECIDO}

$\mathrm{Eu}$, tomei ciência do estudo intitulado "Monitoramento da saúde do trabalhador de enfermagem: promovendo a qualidade de vida no trabalho, através da apresentação oral feita pela pesquisadora, cuja finalidade é contribuir com a construção de um corpo de conhecimentos a respeito dos processos saúde-doença vivenciados pelos trabalhadores de enfermagem em diferentes realidades, a partir da captação de seus fatores geradores de desgaste e fortalecimento. Fui também informado que o objetivo ter como objetivos: resgatar e divulgar a produção científica existente a respeito da saúde do trabalhador de enfermagem, em bancos de dados informatizados e em publicações indexadas de enfermagem; caracterizar a força de trabalho de enfermagem e as instituições de campo de estudo; captar os processos favorecedores e desgastantes, a que estão submetidos os trabalhadores de enfermagem, que implicam nos processos saúde-doença; construir um sistema informatizado que permita o monitoramento em um cenário de estudo; sistematizar meios de divulgação e socialização do conhecimento gerado e as estratégias para sua obtenção. Frete a esses esclarecimentos, declaro meu interesse, por livre e espontânea vontade, em ser sujeito deste. Estou ciente de que os dados por mim fornecidos farão parte do referido estudo, sendo assegurado o sigilo e o anonimato e que poderei interromper esta participação em qualquer etapa da pesquisa, caso eu assim desejar, sem que isso implique em qualquer prejuízo pessoal ou profissional. Tenho conhecimento dos procedimentos para coleta de dados e que estes dados serão posteriormente divulgados.

Data:

Assinatura do funcionário: №. do RG: 
Assinatura do pesquisador:

Nome do pesquisador: Vivian Aline Mininel

№. do RG: 33.578.1335-4

Telefone para contato: 3842-9374 / 3040-3058

Endereço eletrônico: vivian.aline@usp.br 